Review

\title{
Antimicrobial Lipids from Plants and Marine Organisms: An Overview of the Current State-of-the-Art and Future Prospects
}

\author{
Eliana Alves ${ }^{1, *(\mathbb{C})}$, Marina Dias ${ }^{1}$, Diana Lopes ${ }^{1,2}$, Adelaide Almeida $\left.{ }^{3}{ }^{(}\right)$, \\ Maria do Rosário Domingues ${ }^{1,2}$ (D) and Felisa Rey ${ }^{1,2, *(D)}$ \\ 1 Mass Spectrometry Centre, LAQV-REQUIMTE, Department of Chemistry, University of Aveiro, Campus \\ Universitário de Santiago, 3810-193 Aveiro, Portugal; marinadias@ua.pt (M.D.); \\ dianasalzedaslopes@ua.pt (D.L.); mrd@ua.pt (M.d.R.D.) \\ 2 Centre for Environmental and Marine Studies, CESAM, Department of Chemistry, University of Aveiro, \\ Campus Universitário de Santiago, 3810-193 Aveiro, Portugal \\ 3 Centre for Environmental and Marine Studies, CESAM, Department of Biology, University of Aveiro, \\ Campus Universitário de Santiago, 3810-193 Aveiro, Portugal; aalmeida@ua.pt \\ * Correspondence: elianaalves@ua.pt (E.A.); felisa.rey@ua.pt (F.R.)
}

Received: 10 June 2020; Accepted: 22 July 2020; Published: 24 July 2020

\begin{abstract}
In the actual post-antibiotic era, novel ways of rethinking antimicrobial research approaches are more urgent than ever. Natural compounds with antimicrobial activity such as fatty acids and monoacylglycerols have been investigated for decades. Additionally, the interest in other lipid classes as antimicrobial agents is rising. This review provides an overview on the research about plant and marine lipids with potential antimicrobial activity, the methods for obtaining and analyzing these compounds, with emphasis on lipidomics, and future perspectives for bioprospection and applications for antimicrobial lipids. Lipid extracts or lipids isolated from higher plants, algae or marine invertebrates are promising molecules to inactivate a wide spectrum of microorganisms. These lipids include a variety of chemical structures. Present and future challenges in the research of antimicrobial lipids from natural origin are related to the investment and optimization of the analytical workflow based on lipidomics tools, complementary to the bioassay-guided fractionation, to identify the active compound(s). Also, further work is needed regarding the study of their mechanism of action, the structure-activity relationship, the synergistic effect with conventional antibiotics, and the eventual development of resistance to lipids, which, as far as is known, is unlikely.
\end{abstract}

Keywords: fatty acid; lipid extract; lipidomics; macroalga; marine invertebrate; mechanism of action; microalga; minimum inhibitory concentration; monoacylglycerol; natural antimicrobial

\section{Introduction}

The consumption of antibiotics in the world population is alarming. In 2016, the top five World Health Organization (WHO)'s major antibiotic consuming countries were Brazil, Turkey, Iran, Russia, and France, by decreasing order [1]. In Brazil, more than 2000 metric tons of antibiotics were consumed annually, followed by ca. 1000 metric tons in Turkey and Iran [1].

Both misuse and overuse of antibiotics has led to the development of antimicrobial resistance (AMR) in microorganisms, which has been a global problem and a growing threat for many years. Antimicrobial resistant microbes are found in people, animals, food, and the environment (hospital or other health care facilities, water, soil and air). Because of AMR, several disease conditions are becoming harder to treat, as tuberculosis, pneumonia, blood poisoning, gonorrhea, and foodborne diseases [2]. AMR leads to higher medical costs, prolonged hospital stays, and increased mortality, 
causing an economic burden for health care systems. The major cause of AMR is mostly due to misuse of antibiotics.

A number of 700,000 deaths occur worldwide because of drug-resistant diseases [3]. Tuberculosis causes 1.8 million deaths per year, while multidrug-resistant (MDR) tuberculosis causes 250,000 deaths per year and is a global priority for research and development. Gram-negative bacteria can cause death in days because of the lack of treatment options. By 2050, it is foreseen that drug-resistant diseases could cause 10 million deaths each year [3]. In 2017, the WHO identified a priority list of highly antimicrobial-resistant pathogenic microorganisms, also known as superbugs, that have developed survival mechanisms to circumvent the action of last-line antimicrobials (isoniazid, rifampicin, fluoroquinolone, carbapenem, third-generation cephalosporin, or vancomycin) [4]. There are twelve bacteria that have critical and high priority for treatment discovery, besides Mycobacterium tuberculosis, the causing agent of tuberculosis, including the "ESKAPE" pathogens: Enterococcus faecium, Staphylococcus aureus, Klebsiella pneumoniae, Acinetobacter baumannii, Pseudomonas aeruginosa, and Enterobacteriaceae [5]. Superbugs cause 33,000 deaths each year, in Europe, by antibiotic-resistant bacterial infections. Italy is the European country with one-third of all cases (11,000 deaths in total), followed by France (more than 5500 deaths) and Germany (with 2300 deaths) [6,7].

The world now lives the so-called "post-antibiotic era." The current guidelines and recommendations from the WHO claim for an interconnected action and national action plans in a multisectoral and sustained "One Health" approach. This is aimed to tackle AMR and achieve the United Nations' Sustainable Development Goals for 2030 toward humans, food and feed, plants and crops, environment, terrestrial and aquatic animals [8].

According to a recent WHO's report, there are 252 antimicrobial agents in preclinical pipeline, being developed to treat WHO's priority pathogens, but at very early stages of development [9]. Even so, very few target the most critical resistant Gram-negative bacteria, thus, they will generate little benefit over existing treatments [9]. As such, it appears that the future will come up with an increased need for new compounds with antimicrobial activity and combined therapeutic strategies, which can be effective against superbugs and bring revenue to the pharmaceutical industry. At the same time, several alternative approaches to conventional antibiotics have been extensively studied, not only to be used in the clinical field but also in animal health, control insect pest, protect agricultural crops, improve food safety, and water disinfection. Developing strategies include antimicrobial peptides (AMP), phage therapy, photodynamic antimicrobial chemotherapy (PACT), nanoparticles, probiotics, lysins, antibodies, quorum sensing inhibitors, and immunotherapeutic agents [5,10-14]. Combination therapy or multi-target approaches are being developed to hinder antibiotic resistance or to sensitize microorganisms to antibiotic action [15]. Another strategy to overcome AMR is the combination of conventional antibiotics with other molecules, as natural products and/or antimicrobials from natural sources, as plants and marine organisms, to enhance the antimicrobial effect against a wide range of pathogens.

Medicinal plants and marine organisms are natural sources of many antimicrobial compounds [14,16-18]. Plant components with antimicrobial activity include alkaloids, sulfur-containing compounds, diterpenes/terpenoids [19], fatty acids (FA) [20-22], some carbohydrates [23], steroidal glycosides, and phenolic compounds [24]. Both primary and secondary metabolites are "generally recognized as safe" (GRAS) substances and the chance of triggering antimicrobial resistance is low [25]. Simultaneously, marine organisms, mainly slow-moving or sessile, have developed adaptive defense mechanisms to protect themselves against pathogenic microorganisms. In some cases, marine organisms maintain associations with microbiota, being bacterial symbionts responsible by the synthesis of antimicrobial molecules [26,27].

\subsection{Synergistic Effects between Natural Products and Antibiotics}

Phytochemicals exert potential antimicrobial activities against both resistant and sensitive pathogenic microorganisms through distinct mechanisms of action. Additionally, some of them 
exert in vitro synergistic effects when combined with conventional antibiotics [19]. These natural products have intrinsic antibacterial, antiviral, antifungal, and antiparasitic activity, usually in higher concentrations than synthetic compounds, but they can be used to potentiate the effect of drugs. Synergistic effects have been observed by simultaneous administration of phytochemicals with antibiotics by increasing the effectiveness of oxacillin, tetracycline, nalidixic acid, ofloxacin, chloramphenicol, gentamicin, erythromycin, penicillin, ampicillin, kanamycin, and ciprofloxacin, primarily antibiotics from the group of inhibitors of cell wall synthesis and protein synthesis $[25,28]$. Likewise, the combination of phytochemical with antibiotics significantly reduced the values of their minimum inhibitory concentrations (MIC) [19].

On the other side, the effects of antimicrobial compounds from marine organisms in combination with conventional antibiotics have been poorly explored. Synergistic interactions were found in combination of long chain polyunsaturated FA (PUFA) with benzoyl peroxide to inhibit the growth of S. aureus [29]. This synergistic effect of FA suggests an increase in the cell membrane's permeability, improving the penetration of the antimicrobial agent [29]. Fucoidan increased oral bacterial killing when combined with antibiotics [30]. Two AMP, tachycitin and a big defensin from the horseshoe crab Tachypleus tridentatus acted synergistically in antimicrobial activities [31]. Fucofuroeckol-A from the kelp Eisenia bicyclis reversed erythromycin and lincomycin resistance of Propionibacterium acnes and demonstrated a weak synergistic effect with both antibiotics [32]. Two marine oligosaccharides showed a synergistic effect with azithromycin against a wild-type strain of P. aeruginosa [33].

\subsection{Antimicrobial Lipids}

FA, monoacylglycerols (MAG), sterols and terpene derivatives have been the most studied antimicrobial lipid classes over the decades [20-22,34,35]. The efficiency of these lipids over a wide spectrum of microorganisms is linked to their chemical structure and is influenced by the $\mathrm{pH}$ of the medium. The structure-activity relationship between free FA (non-esterified) and bacteria is based on the chemical structure of the FA and depends on the acyl chain length, the stereochemistry, the degree of unsaturation, or on the esterified form of FA [20,21]. Short-chain FA (C6 or lower) are effective against Gram-negative bacteria (high concentration and $\mathrm{pH}$-dependent); long-chain FA (C12 or higher) are effective against Gram-positive bacteria (low concentration and $\mathrm{pH}$-dependent); methyl esters of FA (FAME) decrease bacterial activity; sucrose esters increase bacterial activity; cis-isomers are more active than trans-isomers; unsaturated ones increase the activity against Gram-negative bacteria [21]. FA and MAG are mostly effective against Gram-positive bacteria, quite possibly because of the complexity of the cell wall of Gram-negative bacteria, and the lower complexity and greater porosity of the Gram-positive bacterial wall, made up of several layers of peptidoglycan [36], which provides a degree of porosity to bacteria that allows the penetration of the antimicrobial agent into the cell [10]. In these bacteria, the absence of an outer membrane and the porous structure of the peptidoglycan cell wall allow the entry of antimicrobial molecules through the cell wall [37]. FA are amphipathic molecules with the hydrocarbon chain representing the hydrophobic part, while the carboxylic acid group is hydrophilic. This group can be polar or anionic in aqueous solution depending on the $\mathrm{pH}$ of the medium. However, antimicrobial inactivation studies with free FA isolated from biological matrices (plants or marine organisms) deserve greater attention in the near future, since FA with antimicrobial properties are sometimes identified as the most abundant compounds in the active extracts. However, when they are isolated, they do not exert any activity against the tested microorganisms.

FA have also shown antifungal activity and have the advantage of being non-toxic to the environment as conventional antifungals. Although they have a high degree of specificity, the probability of developing resistance in pathogenic fungi is low [35]. The most important target of antifungal FA is the cell membrane. They increase the fluidity of the membrane, leading to leakage of intracellular components and cell death. Other targets include protein synthesis that can be inhibited by myristic acid (14:0) analogues, FA metabolism and topoisomerase activity that can be inhibited by acetylenic FA, among others [35]. Some are FA produced by plants as a defense mechanism 
against fungal attack such as acetylenic FA. These FA have a triple bond $(C \equiv C)$ and their putative mechanism of action is the inhibition of sphingolipid synthesis [38]. Fungi are more inhibited by acetylenic FA derivatives than by ethylenic FA derivatives (FA with double bonds) [21]. Cyclopropane FA, which have a cyclic structure, also revealed antifungal activity [35]. The synergism of antifungal drugs with antifungal FA increases the susceptibility to those drugs, potentiating and prolonging their effect [39].

The antifungal efficiency of free FA increases with the increase in the carbon chain length. FA with proven activity against several fungi, both yeast and mold species, include saturated (4:0 to 16:0) and unsaturated (4:1 to 22:5) ones, which increase the fungicidal activity because of their greater freedom of movement within the cell membrane [40]. Methylated FA, also known as branched FA, (6-Me 17:1 and 12-Me 14:0), several saturated and unsaturated oxylipins (12:0 to 18:3) having one to three hydroxyl $(\mathrm{OH}-)$ groups have shown antifungal activity as well [40]. Oxylipins are originated from oxidation of PUFA and include different types of oxygenated FA derivatives.

A strong synergistic effect was evidenced on the antimicrobial action of linoleic acid (18:2) and oleic acid (18:1) against S. aureus and Kocuria kristinae, formerly known as Micrococcus kristinae, and also, a strong synergistic effect between 18:2 and MAG [monolaurin, MAG(C12:0)], or monomyristin, [MAG(C14:0)] greater than the isolated effect of 18:2 [41]. The 10- and 14-carbon MAG were effective against Helicobacter pylori, but free FA 14:1 and linolenic acid (18:3) were the most effective against this bacterium [42]. MAG(C10:0) was effective against Neisseria ghonorroeae, MAG(C12:0) against S. aureus and FA 12:0 against methicillin-resistant $S$. aureus (MRSA) and methicillin-sensitive S. aureus (MSSA), as recently reviewed by Yoon et al. (2018) [21]. A great advantage of antimicrobial lipids is that they are difficult to trigger resistance mechanisms in microbes, as observed for pathogenic fungi, as mentioned above [35] and also for bacteria, since they can grow in culture medium in the presence of these lipids, in sublethal concentrations, for up to a year without developing resistance [43].

Despite the promising results, mostly performed with pure commercial compounds, it is necessary to get an insight on the bioactive lipid molecules from natural sources. In some cases, pure lipid compounds were obtained from plant or marine organism extracts after several fractionation and purification steps, for further analysis and identification. There are few research works that were able to isolate a single lipid compound or a class of lipids. Additionally, a complex task is to verify the structure-activity relationship that requires further studies. Electron microscopy techniques and model membrane systems are useful tools to understand the mode of action of lipids toward the microorganisms. This laborious work requires a concerted action from several scientific disciplines as well as many methodological and technological fields and specialized personnel.

Thus, the study of lipids as molecules with antimicrobial potential, may be enhanced in the short term, with the help of lipidomics as an emerging tool for the identification and characterization of lipids (Section 5). This will promote the accurate identification of bioactive compounds, the discovery of new lipids and, eventually, compounds that can be used in combination with existing drugs to aid therapy.

A summary of the actual state-of-the-art on antibiotic resistance and search for novel antimicrobials, as natural product-derived lipids, is illustrated in Figure 1. 


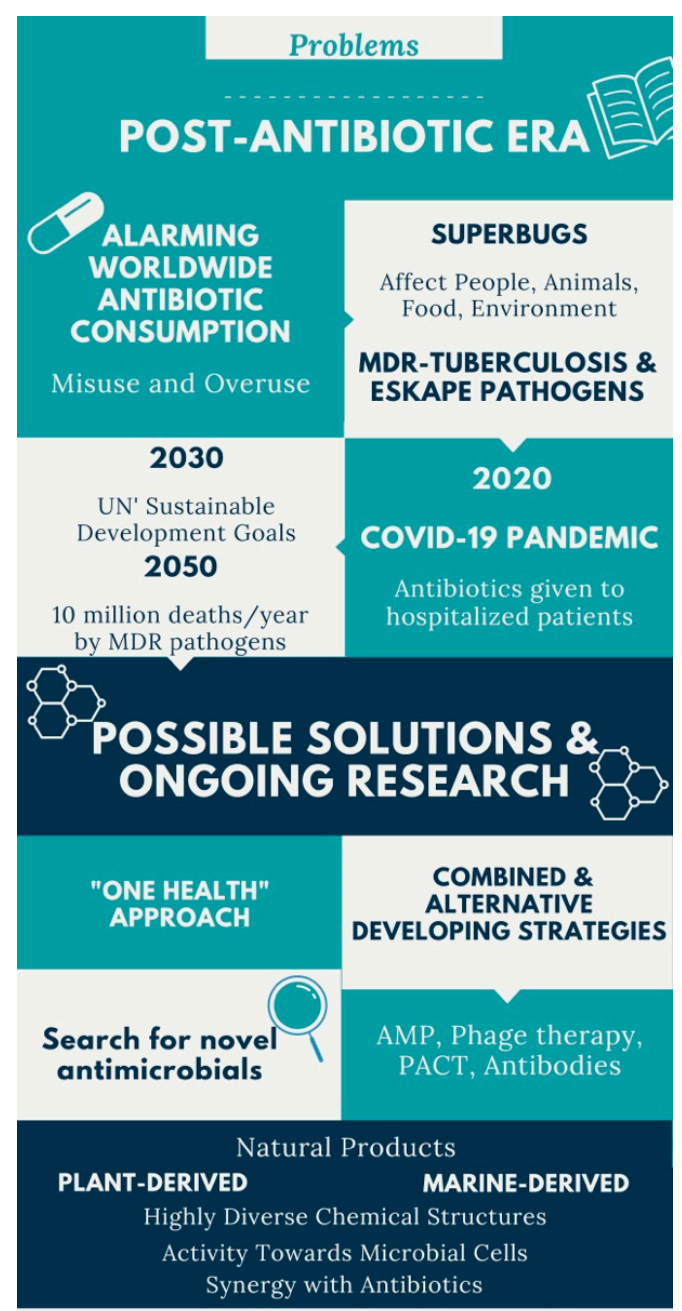

LIPIDS as ANTIMICROBIALS

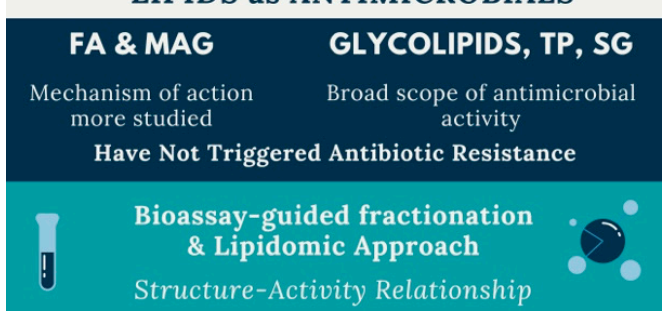

Figure 1. Infographic of the actual state-of-the-art on antibiotic resistance and search for novel antimicrobials, as natural product-derived lipids. Abbreviations: MDR, multidrug resistant; UN, United Nations; AMP, antimicrobial peptides; PACT, photodynamic antimicrobial chemotherapy; FA, fatty acids; MAG, monoacylglycerols; TP, terpenoids; SG, steroidal glycosides.

\subsection{Aim of the Study}

This review aims to provide a critical overview on the research about plant and marine lipids with potential antimicrobial activity, the methods for obtaining and analyzing these compounds with emphasis on lipidomics, and future perspectives for bioprospecting and applying these antimicrobial lipids.

\section{Antimicrobial Lipids from Plants}

Over the evolution, higher plants have developed several resilience strategies that allow them to resist or escape external attacks (e.g., microorganisms, pathogens, and predators). Their innate immune system had to be equipped with highly complex mechanisms of resistance and survival. 
The defense mechanisms of plants are unique and consist of both physical barriers and production of secondary metabolites. Plant secondary metabolites are formed in particular biosynthetic pathways by means of substrate-specific enzymes. The precursors of these secondary metabolites stem from primary metabolites, such as amino acids, FA, sugars, or acetyl-CoA. Some of the secondary metabolites serve as constitutive chemical barriers against the microbial attack (phytoanticipins) while others serve as inducible antimicrobials (phytoalexins) [44].

Oxylipins are a large family of plants' secondary metabolites derived from PUFA that make part of their immune system and play key roles as antimicrobial agents. They are formed through enzymatic or radical oxidation of FA 18:2 and 18:3, in order to protect plants against pests and pathogens [45]. The enzymatic biosynthesis of these molecules is triggered by an alpha-dioxygenase (DOX) and by lipoxygenases (LOX) $[46,47]$ that lead to the formation of the different types of molecules, including hydroxy-, hydroperoxy-, divinyl-, oxo-, and keto-derivatives of FA. Oxylipins are formed during abiotic and biotic stresses [48]. They are plant signaling molecules that can induce cell death and have an effect on the growth of eukaryotic microbes [45]. A deeper knowledge on plant response to stresses at molecular, physiological and metabolic levels will allow the development of new plant-derived antimicrobial molecules for use in the clinical field and as biopesticides [48].

The search for novel antimicrobials has led to exploring also amide derivatives of FA because they are natural self-defense agents in plants. FA amides are bioactive lipids [49] formed by the amidation of long chain saturated and unsaturated FA (UFA) [50]. They have higher antimicrobial activity against yeasts and bacteria than unmodified FA [51]. Amide derivatives of FA possess a broad bioactivity against different pathologic conditions (bacterial and parasitic infections, cancer, inflammation, etc.,) and their mechanisms of action imply protein synthesis inhibition and membrane leakage [52]. Also, microorganisms inside healthy plant tissues are unique to explore novel bioactive compounds. The FA and their amides from plant's endogenous microorganisms have been scarcely reported despite being bioactive in a variety of processes and should be more explored as new therapeutic agents [52].

Lipids represent up to $7 \%$ of the dry weight of the leaves of higher plants and are important constituents of cell membranes, chloroplasts, and mitochondria [53]. Besides their structural function as main constituents of cell membranes, they have functional roles in plants (intracellular mediators, extracellular signalers, inter-species communication, and plant defense) and also serve as energy reserves (namely in seeds during germination) [21]. Palmitic acid (16:0) is the major saturated FA in leaf lipids. On the other hand, chloroplast membranes can have up to 90\% $\alpha-18: 3$ FA in some lamellae [21]. FA exist in plants mainly linked to more complex molecules, as acylglycerols, esterified to a glycerol backbone in the form of triacylglycerols, sterol esters, MAG and diacylglycerols, phospholipids, or glycolipids. Several lipid classes, besides FA and MAG, have been identified in a diverse group of higher plants and tested for their antimicrobial activity, as will be detailed in the next sub-sections. Figure 2 illustrates the chemical structures of the different lipid classes with antimicrobial activity isolated from natural sources.

\subsection{Extraction and Isolation of Plant Lipids}

Studies that extract or isolate lipids from plants to test their antimicrobial activity are scarce (Table 1). The biomass used to extract lipids includes leaves, fruits, seeds, stems, rhizomes, shoots, stem barks, and heartwoods (Table 1). Lipid extraction from plants is usually carried out with organic solvents of different polarities (mainly $n$-hexane, $\mathrm{CHCl}_{3}, \mathrm{CH}_{2} \mathrm{Cl}_{2}$, EtOAc, $\mathrm{EtOH}, \mathrm{BuOH}, \mathrm{MeOH}$, and their mixtures) (Table 1). Liquid/liquid extractions or Soxhlet extraction are commonly performed to obtain total lipid extracts [54-58]. Instead of analyzing one lipid class or one lipid molecule, some studies have analyzed the total lipid extracts that were obtained by sequential extraction. 


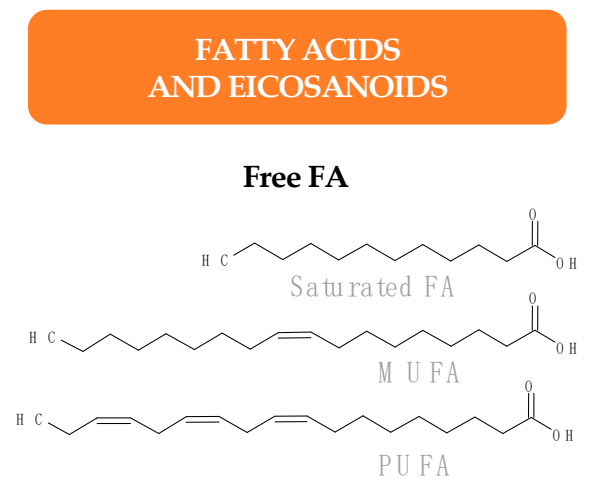

Halogenated FA

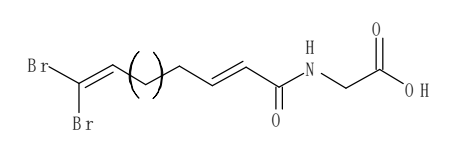

Acetylenic acid
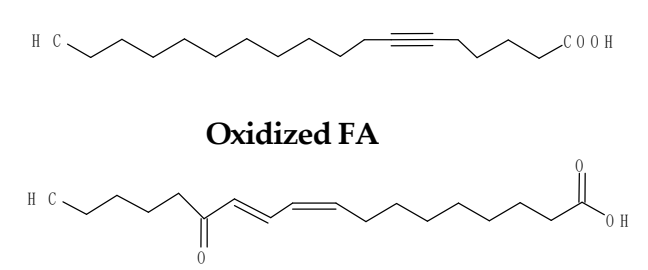

FA esters

(N)

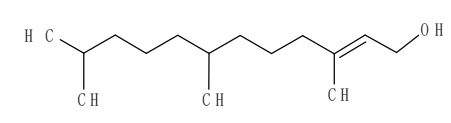

PHOSPHOLIPIDS

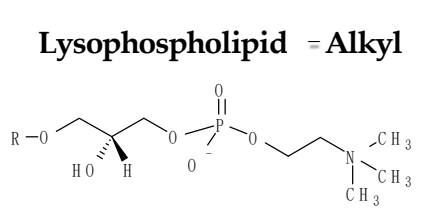

Phosphatidylcholine

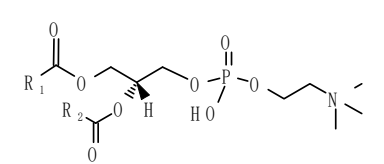

Phosphatidylethanolamine

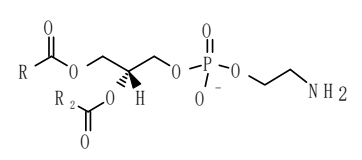

Phosphatidylinositol

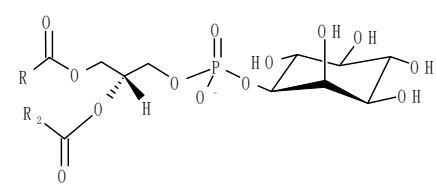

Phosphatidylserine

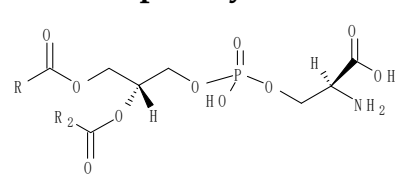

STEROL LIPIDS
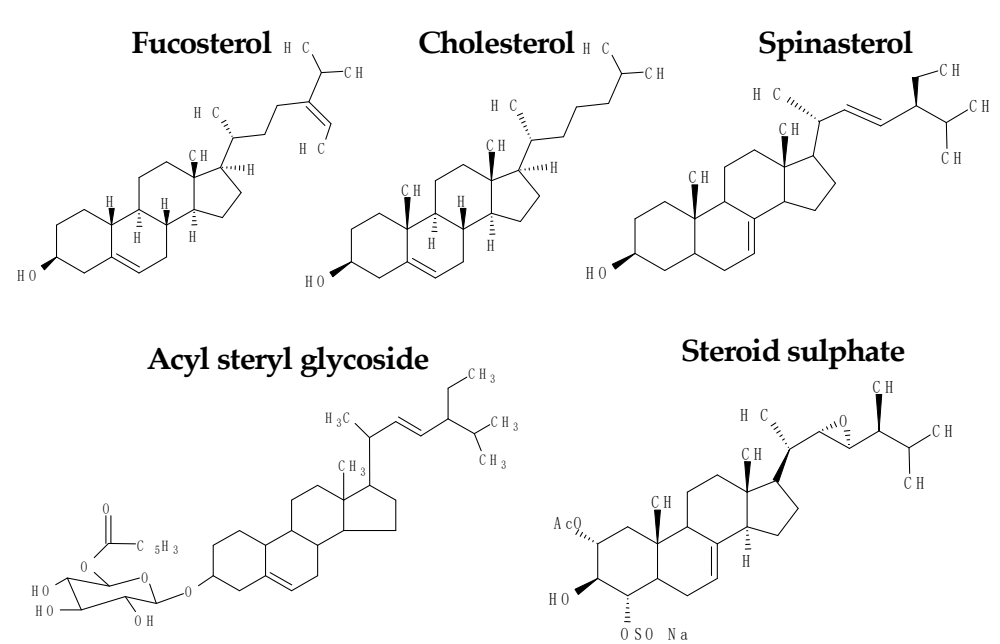

Steroid sulphate
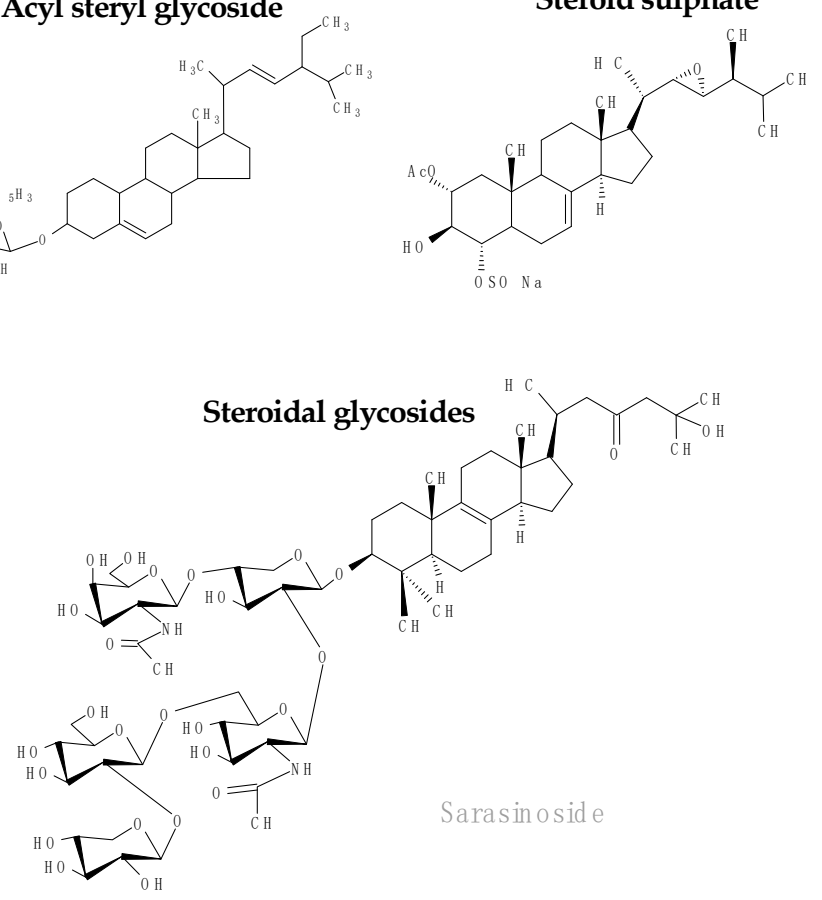

Figure 2. Cont. 


\section{GLYCEROGLYCOLIPIDS}

Monogalactosyldiacylglycerol

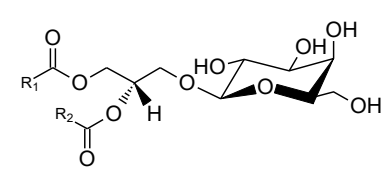

] igalactosyldiacylglycerol

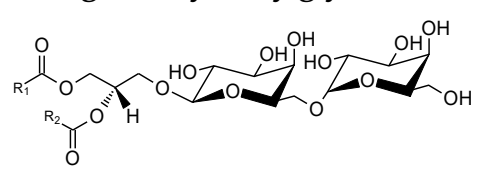

Sulphoquinovosyldiacylglycerol

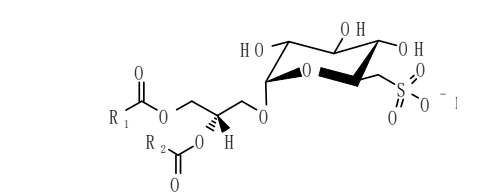

Caminoside

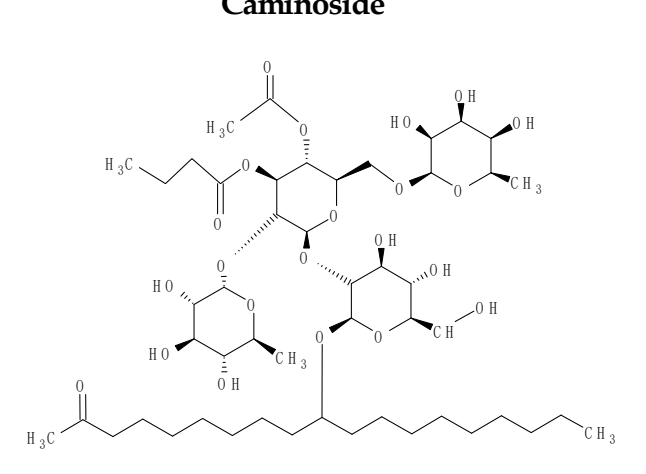

\section{SPHINGOLIPIDS}

Sphingolipid

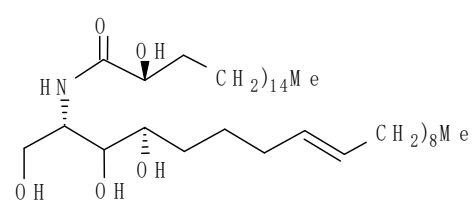

\section{Ceramide}

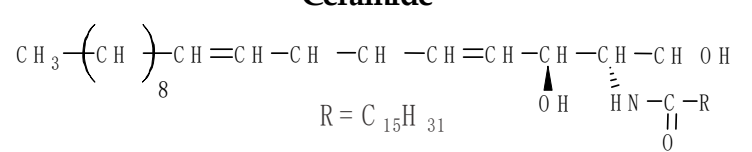

Artemceramide-B

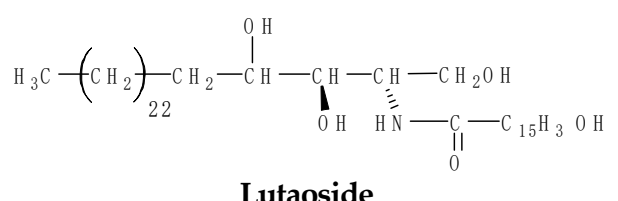

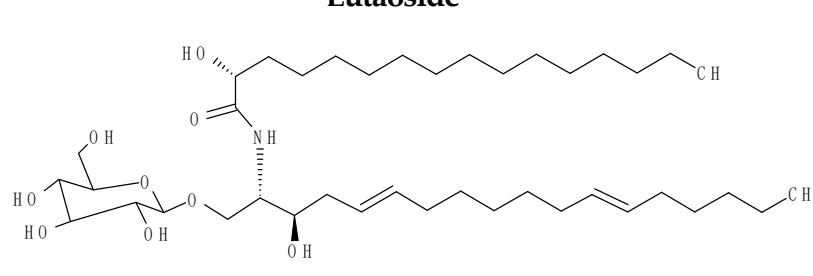

Panduramide

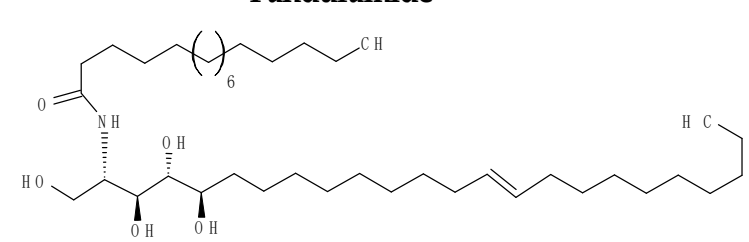

OTHER LIPIDS

Monoacylglycerol

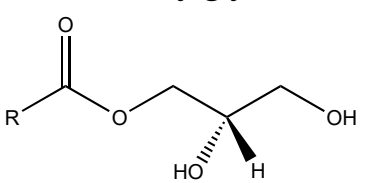

Diacylglycerol

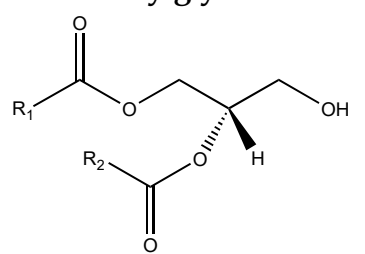

Triacylglycerol

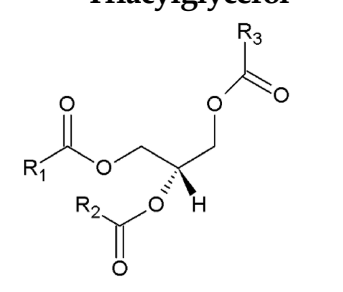

Phenolic aldehydes

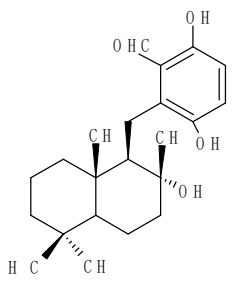

Siphonod icty al-A

Figure 2. Cont. 


\section{TERPENOIDS}

Nortriterpenoids
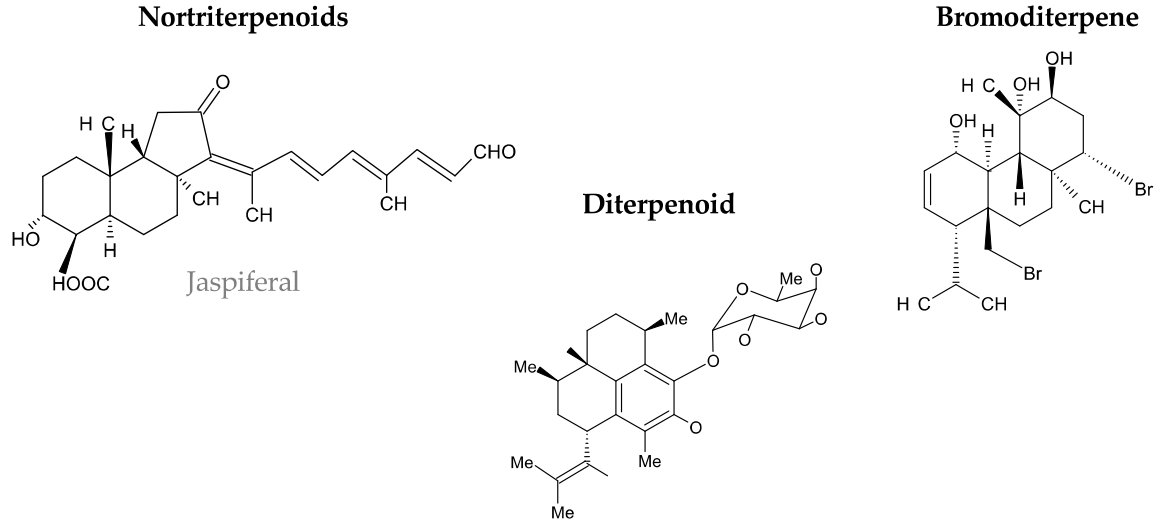

Cembranoid diterpene

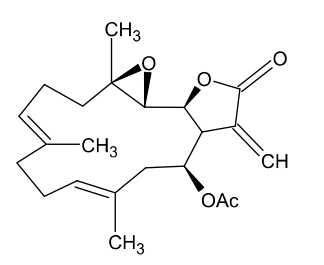

Meroterpenes

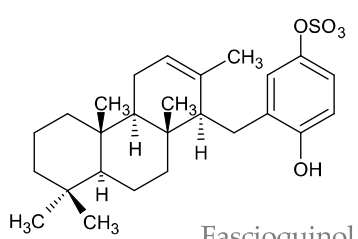

Fascioquinol
Sesterterpenes sulfates

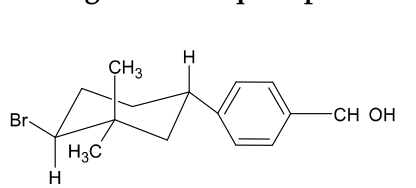

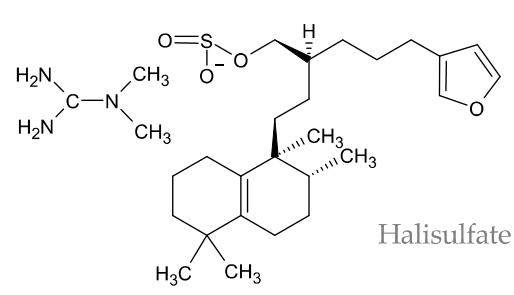

\section{Meroterpene derivatives}

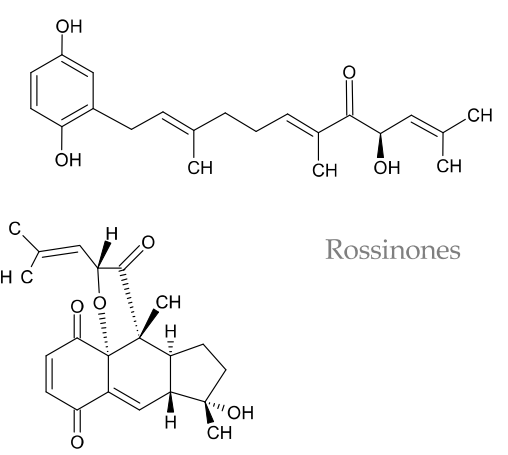

Figure 2. Chemical structures of the different lipid classes isolated from natural sources with antimicrobial activity. 
Table 1. Plant potential antimicrobial lipids or lipid-rich extracts, their origin and extraction method grouped by botanic family.

\begin{tabular}{|c|c|c|c|c|c|c|c|}
\hline Botanical Name & Family & Common Name & $\begin{array}{l}\text { Country of } \\
\text { Collection }\end{array}$ & Plant Part & $\begin{array}{c}\text { Extracting } \\
\text { Solvent/Method }\end{array}$ & $\begin{array}{l}\text { Isolated Lipids or } \\
\text { Lipid Mixtures }\end{array}$ & Ref. \\
\hline $\begin{array}{c}\text { Sesuvium } \\
\text { portulacastrum } \mathrm{L} .\end{array}$ & Aizoaceae & Sea purslane & India & Leaves & $\begin{array}{l}\mathrm{MeOH} / \text { benzene/sulfuric } \\
\text { acid }(200: 100: 10, v / v)\end{array}$ & FAME & {$[60]$} \\
\hline $\begin{array}{l}\text { Blutaparon } \\
\text { portulacoides (A. } \\
\text { St.-Hil.) Mears }\end{array}$ & & Capotiraguá & Brazil & Roots & $\mathrm{EtOH}$ & $\begin{array}{c}\text { Acyl steryl glycosides } \\
\text { (sitosteryl } \\
\text { 3- } \beta \text {-O-glucoside } \\
\text { 6'-O-palmitate and } \\
\text { stigmasteryl } \\
\text { 3- } \beta \text {-O-glucoside } \\
\text { 6'-O-palmitate) }\end{array}$ & [70] \\
\hline $\begin{array}{l}\text { Arthrocnemum indicum } \\
\text { (Willd.) Moq., } \\
\text { Salicornia brachiata } \\
\text { Roxb., Suaeda maritima } \\
\text { (L.) Dumort. and } \\
\text { Suaeda monoica Forsk. }\end{array}$ & Amaranthaceae & $\begin{array}{l}\text { Glasswort for } \\
\text { Salicornia genus, } \\
\text { herbaceous } \\
\text { seepweed for } S \text {. } \\
\text { maritima, and } \\
\text { South-Indian } \\
\text { seepweed for } S \text {. } \\
\text { monoica }\end{array}$ & India & $\begin{array}{c}\text { Shoots of } A \text {. } \\
\text { indicum and } S \text {. } \\
\text { brachiata, and } \\
\text { leaves of } S \text {. } \\
\text { maritima and } S . \\
\text { monoica }\end{array}$ & $\begin{array}{c}\text { Dry } \\
\mathrm{MeOH} / \text { benzene/sulfuric } \\
\text { acid }(200: 100: 10, v / v)\end{array}$ & FAME & [61] \\
\hline Alternanthera brasiliana & & Brazilian joyweed & Brazil & $\begin{array}{l}\text { Root, stem and } \\
\text { leaves }\end{array}$ & EtOH and EtOAc & Linoleate oxylipins & [65] \\
\hline Phoenix dactylifera $\mathrm{L}$. & Arecaceae & Date palm & India & Seeds & $\mathrm{CHCl}_{3}$ and acetone & Sterol and triterpenes & [66] \\
\hline $\begin{array}{c}\text { Asphodelus aestivus } \\
\text { Brot. }\end{array}$ & $\begin{array}{l}\text { Asphodelaceae } \\
\text { (formerly } \\
\text { Liliaceae) }\end{array}$ & Summer asphodel & Turkey & Seeds & $\begin{array}{l}\text { Petroleum ether with } \\
\text { Soxhlet extractor }\end{array}$ & $\begin{array}{c}\text { FA (C4:0, 6:0, 8:0, 10:0, } \\
\text { 16:0, 18:0, 21:0, 24:0, 14:1, } \\
\text { 15:1, 18:1n9t, 20:1, 24:1, } \\
\text { 18:2, 18:2n6t, 18:2n6c, } \\
\text { 20:2n6, 20:3n3, 22:6n3, } \\
\text { and others unidentified) }\end{array}$ & [54] \\
\hline Artemisia incisa Pamp. & Asteraceae & & Pakistan & Roots & $\begin{array}{c}\mathrm{MeOH} \text { and recovered } \\
\text { after elution on a } \mathrm{SiO}_{2} \\
\text { column with } \\
\mathrm{CH}_{2} \mathrm{Cl}_{2} / \mathrm{MeOH}(9: 1, v / v) \\
\text { following previous } \\
\text { elution with } \\
n \text {-hexane/EtOAc }(5: 4, v / v)\end{array}$ & Artemceramide-B & [73] \\
\hline
\end{tabular}


Table 1. Cont.

\begin{tabular}{|c|c|c|c|c|c|c|c|}
\hline Botanical Name & Family & Common Name & $\begin{array}{l}\text { Country of } \\
\text { Collection }\end{array}$ & Plant Part & $\begin{array}{c}\text { Extracting } \\
\text { Solvent/Method }\end{array}$ & $\begin{array}{l}\text { Isolated Lipids or } \\
\text { Lipid Mixtures }\end{array}$ & Ref. \\
\hline $\begin{array}{l}\text { Pteranthus dichotomus } \\
\text { Forssk. (also known } \\
\text { as P. echinatus Desf.) }\end{array}$ & Caryophyllaceae & & Algerian Sahara & Aerial parts & $\begin{array}{l}\mathrm{MeOH} / \mathrm{H}_{2} \mathrm{O}(80: 20, v / v) \text {. } \\
\text { Aqueous phase extracted } \\
\text { successively with } \\
\text { petroleum ether, EtOAc } \\
\text { and } n \text { - } \mathrm{BuOH} \text {. EtOAc } \\
\text { fraction contained the } \\
\text { sterols and steryl } \\
\text { glycoside. BuOH fraction } \\
\text { contained the } \\
\text { glyceroglycolipids and the } \\
\text { cerebroside. }\end{array}$ & $\begin{array}{c}\text { BuOH fraction } \\
\text { contained the } \\
\text { compounds: } \\
\text { 1-O-palmitoyl-3- } \\
\text { O-(6-sulfo- } \alpha \text {-D- } \\
\text { quinovopyranosyl)- } \\
\text { glycerol, } 1,2 \text {-di-O- } \\
\text { palmitoyl-3-O-(6-sulfo- } \\
\alpha \text {-D-quinovopyranosyl)- } \\
\text { glycerol and soya } \\
\text { cerebroside I. EtOAc } \\
\text { fraction contained the } \\
\text { compounds: } \\
\text { stigmat-7-en-3-ol, } \\
\text { spinasterol, } \beta \text {-sitosterol } \\
\text { and } \beta \text { - } \\
\text { sitosterol-3-O-glycoside }\end{array}$ & [78] \\
\hline Cucumis sativus L. & Cucurbitaceae & Cucumber & China & Stems & $\begin{array}{l}\mathrm{CHCl}_{3} \text { fraction of the } \\
\text { crude methanolic extract }\end{array}$ & $\begin{array}{c}\text { Sphingolipids } \\
{\left[(2 S, 3 S, 4 R, 10 E)-2-\left[\left(2^{\prime} R\right)-2-\right.\right.} \\
\text { hydroxytetracosanoylami } \\
\text { no]-1,3,4-octadecanetriol- } \\
\text { 10-ene, 1-O- } \beta \text {-D- } \\
\text { glucopyranosyl-(2S,3S,4R, } \\
10 E)-2-\left[\left(2^{\prime} R\right)-2 \text {-hydroxy }\right. \\
\text { tetracosanoylamino]-1,3,4- } \\
\text { octadecanetriol-10-ene } \\
\text { and soya-cerebroside I] }\end{array}$ & [74] \\
\hline Excoecaria agallocha & Euphorbiaceae & $\begin{array}{l}\text { Blind-your-eye } \\
\text { mangrove }\end{array}$ & India & Leaves & $\begin{array}{l}\text { Dry } \mathrm{MeOH} \text {, benzene and } \\
\text { sulfuric acid }(200: 100: 10 \text {, } \\
\qquad / v)\end{array}$ & FAME & [62] \\
\hline
\end{tabular}


Table 1. Cont

\begin{tabular}{|c|c|c|c|c|c|c|c|}
\hline Botanical Name & Family & Common Name & $\begin{array}{l}\text { Country of } \\
\text { Collection }\end{array}$ & Plant Part & $\begin{array}{c}\text { Extracting } \\
\text { Solvent/Method }\end{array}$ & $\begin{array}{l}\text { Isolated Lipids or } \\
\text { Lipid Mixtures }\end{array}$ & Ref. \\
\hline $\begin{array}{l}\text { Albizia adianthifolia } \\
\text { (Schumach) and } \\
\text { Pterocarpus angolensis } \\
\text { (DC) }\end{array}$ & Fabaceae & $\begin{array}{l}\text { Flat crown Albizia } \\
\text { and African teak, } \\
\text { respectively }\end{array}$ & $\begin{array}{l}\text { Nigeria and } \\
\text { Botswana, } \\
\text { respectively }\end{array}$ & $\begin{array}{l}\text { Heartwood of } A \text {. } \\
\text { adianthifolia and } \\
\text { stem bark of } P \text {. } \\
\text { angolensis }\end{array}$ & $\begin{array}{l}n \text {-hexane, } \mathrm{CHCl}_{3}, \mathrm{MeOH}, \\
\text { and } 10 \% \mathrm{MeOH}(\mathrm{aq})\end{array}$ & $\begin{array}{l}n \text {-hexadecanoic acid } \\
\text { (palmitic acid); oleic } \\
\text { acid; chondrillasterol; } \\
\text { stigmasterol, 24S } \\
5 \alpha \text {-stigmast-7-en-3-ol; } \\
\text { 9,12-octadecadienoic } \\
\text { acid (Z,Z)-, methyl ester; } \\
\text { trans-13-octadecanoic } \\
\text { acid, methyl ester; } \\
\text { tetradecanoic acid; } \\
\text { hexadecanoic acid, } \\
\text { methyl ester; } \\
\text { octadecanoic acid }\end{array}$ & [79] \\
\hline Baphia massaiensis & & Jasmine pea & Botswana & Seeds & $\begin{array}{l}n \text {-hexane/1-propanol (3:1, } \\
v / v) \text { with Soxhlet extractor }\end{array}$ & Seed oil (total FA) & [80] \\
\hline $\begin{array}{l}\text { Cassia tora L. (or Senna } \\
\text { tora L. Roxb.) }\end{array}$ & & Sickle Senna & India & Leaves and stem & $\begin{array}{l}\text { Petroleum ether with } \\
\text { Soxhlet extractor }\end{array}$ & $\begin{array}{l}\text { FA (the major were } \\
\text { palmitic acid, linoleic } \\
\text { acid, linolenic acid, } \\
\text { margaric acid, melissic } \\
\text { acid, and behenic acid) }\end{array}$ & [55] \\
\hline $\begin{array}{c}\text { Trigonella } \\
\text { foenum-graecum } \mathrm{L} .\end{array}$ & & Fenugreek & India & Seeds & $\begin{array}{c}\text { Supercritical fluid } \\
\text { extraction }\left(40-60^{\circ} \mathrm{C} \text { and }\right. \\
10-25 \mathrm{Mpa})\end{array}$ & $\begin{array}{l}\text { Conjugated linoleic acid } \\
\text { methyl ester, saturated } \\
\text { FAME, steroids }\end{array}$ & [63] \\
\hline $\begin{array}{c}\text { Quercus } \\
\text { leucotrichophora A. } \\
\text { Camus }\end{array}$ & Fagaceae & Banjh oak & India & Fruits & $\begin{array}{l}85 \% \text { aqueous EtOH. } \\
\text { Ethanolic extract } \\
\text { fractionated with hexane } \\
\text { and EtOAc using Soxhlet } \\
\text { extractor. Hexane extract } \\
\text { was analyzed. }\end{array}$ & FAME & [56] \\
\hline $\begin{array}{c}\text { Quercus } \\
\text { leucotrichophora A. } \\
\text { Camus }\end{array}$ & & Banjh oak & $\begin{array}{c}\text { Garhwal region of } \\
\text { Himalaya }\end{array}$ & Leaves and bark & $\mathrm{MeOH}$ & $\begin{array}{c}\text { FA; linoleic acid in stem } \\
\text { bark and leaves extracts } \\
\text { and cis-vaccenic acid in } \\
\text { stem bark }\end{array}$ & [81] \\
\hline
\end{tabular}


Table 1. Cont.

\begin{tabular}{|c|c|c|c|c|c|c|c|}
\hline Botanical Name & Family & Common Name & $\begin{array}{l}\text { Country of } \\
\text { Collection }\end{array}$ & Plant Part & $\begin{array}{c}\text { Extracting } \\
\text { Solvent/Method }\end{array}$ & $\begin{array}{l}\text { Isolated Lipids or } \\
\text { Lipid Mixtures }\end{array}$ & Ref. \\
\hline $\begin{array}{l}\text { Vitex altissima L., } V . \\
\text { negundo } \mathrm{L} . \text { and } V . \\
\text { trifolia } \mathrm{L} .\end{array}$ & Lamiaceae & $\begin{array}{l}\text { Peacock chaste } \\
\text { tree, Chinese } \\
\text { chaste tree, and } \\
\text { simpleleaf } \\
\text { chastetree, } \\
\text { respectively }\end{array}$ & India & Leaves & $\begin{array}{c}\text { Dry } \\
\mathrm{MeOH} / \text { benzene/sulfuric } \\
\text { acid }(200: 100: 10, v / v)\end{array}$ & FAME & [64] \\
\hline Linum usitatissimum L. & Linaceae & $\begin{array}{c}\text { Common flax or } \\
\text { linseed }\end{array}$ & Algeria & Seeds & $\begin{array}{l}\text { Petroleum ether with } \\
\text { Soxhlet extractor }\end{array}$ & FAME & [57] \\
\hline $\begin{array}{l}\text { Scaphium macropodum } \\
\text { (Miq.) Beumee ex. } \\
\text { Heyne }\end{array}$ & Malvaceae & $\begin{array}{l}\text { Malva nut or } \\
\text { Kembang } \\
\text { semangkok }\end{array}$ & Malaysia & Stem bark & $\mathrm{MeOH}$ & $\begin{array}{l}\text { Methyl hexadecanoate, } \\
\text { hexadecanoic acid }<n->\end{array}$ & [82] \\
\hline $\begin{array}{c}\text { Melastoma } \\
\text { malabathricum } \mathrm{L} .\end{array}$ & Melastomataceae & $\begin{array}{l}\text { Planter's } \\
\text { rhododendron or } \\
\text { Sendudok }\end{array}$ & Malaysia & Leaves & $\begin{array}{c}\mathrm{MeOH} / \mathrm{H}_{2} \mathrm{O}(4: 1, v / v), \\
\text { defatted with petroleum } \\
\text { ether and extracted with } \\
\mathrm{CHCl}_{3} \text {. Lipids recovered } \\
\text { after elution of the } \mathrm{CHCl}_{3} \\
\text { extract by } \mathrm{SiO}_{2} \text { column } \\
\text { with } \\
\mathrm{CHCl}_{3} / \text { acetone/MeOH } \\
(10: 9: 1, v / v) .\end{array}$ & $\begin{array}{c}\text { Steryl glycoside: } \\
\beta \text {-sitosterol } \\
\text { 3-O- } \beta \text { - } D \text {-glucopyranoside }\end{array}$ & [69] \\
\hline $\begin{array}{l}\text { Azadirachta indica A. } \\
\text { Juss }\end{array}$ & & Neem & India & Leaves & $\begin{array}{c}\text { MeOH. Recovered after } \\
\text { elution on a } \mathrm{SiO}_{2} \text { column } \\
\text { with } \mathrm{CHCl}_{3} / \mathrm{MeOH}(9: 1 \text {, } \\
v / v)\end{array}$ & SQDG & [71] \\
\hline $\begin{array}{l}\text { Azadirachta indica A. } \\
\text { Juss }\end{array}$ & Meliaceae & Neem & India & Leaves & $\begin{array}{l}\text { Petroleum ether }(60-80 \\
\left.{ }^{\circ} \mathrm{C}\right) \text { for } 24 \mathrm{~h} \text { and extracted } \\
\text { thrice with } \mathrm{MeOH} \text { for } 48 \mathrm{~h} \\
\text { each time at room } \\
\text { temperature }\end{array}$ & SQDG & [72] \\
\hline $\begin{array}{c}\text { Carapa guianensis Aubl. } \\
\text { and Carapa vasquezii } \\
\text { Kenfack }\end{array}$ & & Andiroba & Brazil & Seed oil & $\begin{array}{l}n \text {-hexane with Soxhlet } \\
\text { extractor }\end{array}$ & $\begin{array}{c}\text { FA, FAME, squalene, } \\
\beta \text {-sitosterol }\end{array}$ & [58] \\
\hline
\end{tabular}


Table 1. Cont.

\begin{tabular}{|c|c|c|c|c|c|c|c|}
\hline Botanical Name & Family & Common Name & $\begin{array}{l}\text { Country of } \\
\text { Collection }\end{array}$ & Plant Part & $\begin{array}{c}\text { Extracting } \\
\text { Solvent/Method }\end{array}$ & $\begin{array}{l}\text { Isolated Lipids or } \\
\text { Lipid Mixtures }\end{array}$ & Ref. \\
\hline Ficus lutea Vahl & \multirow[t]{2}{*}{ Moraceae } & $\begin{array}{l}\text { Giant-leaved fig or } \\
\text { Lagos rubbertree }\end{array}$ & Cameroon & Woods & $\begin{array}{c}\mathrm{CH}_{2} \mathrm{Cl}_{2} / \mathrm{MeOH}(1: 1, v / v) \\
\text { and elution with } \\
\text { EtOAc/10\% MeOH }\end{array}$ & $\begin{array}{c}\text { Glycosphingolipid } \\
{[1-O-\beta \text {-D- }} \\
\text { glucopyranosyl- }(2 S, 3 R, \\
5 E, 12 E)-2 N-\left[\left(2^{\prime} R\right)-\right. \\
\text { hydroxyhexadecanoyl]- } \\
\text { octadecasphinga-5,12- } \\
\text { dienine] named } \\
\text { lutaoside }\end{array}$ & [76] \\
\hline Ficus pandurata Hance & & Fiddle leaf fig & Egypt & Fruits & $\begin{array}{c}70 \% \mathrm{MeOH} . \mathrm{MeOH} \\
\text { extract fractionated on a } \\
\mathrm{SiO}_{2} \text { column and purified } \\
\text { by semi-preparative } \\
\text { HPLC to afford pure } \\
\text { ceramides }\end{array}$ & $\begin{array}{c}\text { Ceramides } \\
\text { [panduramides A-D, } \\
\text { and newbouldiamide] }\end{array}$ & [75] \\
\hline $\begin{array}{l}\text { Kunzea ericoides (A. } \\
\text { Rich) J. Thompson }\end{array}$ & Myrtaceae & $\begin{array}{c}\text { Kanuka } \\
\text { (Maori), white } \\
\text { manuka (Maori) or } \\
\text { the white tea tree } \\
\text { (English) }\end{array}$ & Australia & Leaves and twigs & $\begin{array}{l}\mathrm{CH}_{2} \mathrm{Cl}_{2}: \mathrm{MeOH}(1: 1, v / v) \\
\mathrm{CH}_{2} \mathrm{Cl}_{2}: \mathrm{MeOH}(2: 1, v / v) \\
\quad \text { and } \mathrm{CH}_{2} \mathrm{Cl}_{2} \text { (neat) }\end{array}$ & $\begin{array}{c}\text { Steryl esters, } \\
\text { triacylglycerols, free FA, } \\
\text { sterols, and } \\
\text { phospholipids }\end{array}$ & [77] \\
\hline $\begin{array}{l}\text { Pentagonia gigantifolia } \\
\text { Ducke }\end{array}$ & \multirow[t]{2}{*}{ Rubiaceae } & & Peru & Roots & $\begin{array}{c}95 \% \text { EtOH. EtOH extract } \\
\text { was fractionated on a } \mathrm{SiO}_{2} \\
\text { column using } \\
\mathrm{CHCl}_{3} / \mathrm{MeOH} \text { from } 0 \% \text { to } \\
100 \% \mathrm{MeOH} \text {. Fraction } \\
\text { eluted with } 2 \% \\
\mathrm{MeOH} / \mathrm{CHCl}_{3} \text { was } \\
\text { separated on } \mathrm{C}_{18 \mathrm{SiO}_{2}} \\
\text { using } 85 \% \text { to } 90 \% \mathrm{MeOH} \text {. }\end{array}$ & $\begin{array}{l}\text { Acetylenic acids: } \\
\text { 6-octadecynoic acid and } \\
\text { 6-nonadecynoic acid }\end{array}$ & [38] \\
\hline $\begin{array}{l}\text { Hedyotis pilulifera (Pit.) } \\
\text { T.N. Ninh }\end{array}$ & & & Vietnam & Aerial parts & $\begin{array}{c}\mathrm{MeOH} \text { at } 60^{\circ} \mathrm{C} \text {, } \\
\text { suspended in water and } \\
\text { successively partitioned } \\
\text { with } \mathrm{CHCl}_{3} \text { and EtOAc. } \\
\text { EtOAc extract fractionated } \\
\text { on a } \mathrm{SiO}_{2} \text { column. }\end{array}$ & $\begin{array}{l}\text { Triterpenoids, steroids, } \\
\text { FA, glycolipids, and a } \\
\text { ceramide }\end{array}$ & [83] \\
\hline
\end{tabular}


Table 1. Cont

\begin{tabular}{|c|c|c|c|c|c|c|c|}
\hline Botanical Name & Family & Common Name & $\begin{array}{l}\text { Country of } \\
\text { Collection }\end{array}$ & Plant Part & $\begin{array}{c}\text { Extracting } \\
\text { Solvent/Method }\end{array}$ & $\begin{array}{l}\text { Isolated Lipids or } \\
\text { Lipid Mixtures }\end{array}$ & Ref \\
\hline $\begin{array}{l}\text { Withania somnifera } \text { (L.) } \\
\text { Dunal, Euphorbia hirta } \\
\text { L., Terminalia chebula } \\
\text { Retz. }\end{array}$ & $\begin{array}{c}\text { Solanaceae, } \\
\text { Euphorbiaceae, } \\
\text { Combretaceae }\end{array}$ & $\begin{array}{c}\text { Ashwaganda, } \\
\text { asthma-plant, } \\
\text { black myrobalan }\end{array}$ & India & $\begin{array}{c}\text { Fruits, leaf, stem, } \\
\text { and root from } W \text {. } \\
\text { somnifera and } E . \\
\text { hirta and fruits, } \\
\text { leaf, stem, and } \\
\text { stem bark from } T \text {. } \\
\text { chebula }\end{array}$ & EtOAc & Sterols fraction & [67] \\
\hline $\begin{array}{l}\text { Kaempferia pandurata } \\
\text { Roxb. (synonym of } \\
\text { Boesenbergia rotunda } \\
\text { (L.) Mansf.) and Senna } \\
\text { alata (L.) Roxb. }\end{array}$ & $\begin{array}{c}\text { Zingiberaceae and } \\
\text { Fabaceae, } \\
\text { respectively }\end{array}$ & $\begin{array}{l}\text { Fingerroot and } \\
\text { candle bush, } \\
\text { respectively }\end{array}$ & Indonesia & $\begin{array}{l}\text { Leaf of } S \text {. alata and } \\
\text { rhizome of } K . \\
\text { pandurata }\end{array}$ & $\mathrm{EtOH}(96 \%)$ & Sterols and triterpenoid & {$[68]$} \\
\hline $\begin{array}{c}\text { Zygophyllum oxianum } \\
\text { Boriss. }\end{array}$ & Zygophyllaceae & Beancaper & Uzbekistan & $\begin{array}{l}\text { Leaves, stems, and } \\
\text { fruit }\end{array}$ & $\begin{array}{c}\text { Acetone and } \\
\mathrm{CHCl}_{3}: \mathrm{MeOH}(2: 1, v / v) \text { for } \\
\text { total lipid extraction. } \\
\text { Total lipids from each } \\
\text { plant part separated in } \\
\mathrm{SiO}_{2} \text { columns. Neutral } \\
\text { lipids eluted with } \mathrm{CHCl}_{3} ; \\
\text { glycolipids with acetone; } \\
\text { phospholipids with } \\
\text { MeOH. }\end{array}$ & $\begin{array}{l}\text { Total lipid extract from } \\
\text { leaves, stems and aerial } \\
\text { organs (hydrocarbons, } \\
\text { triterpenol and steryl } \\
\text { esters, triacylglycerols, } \\
\text { free FA, sterols, } \\
\text { phospholipids) }\end{array}$ & [59] \\
\hline
\end{tabular}


In order to obtain a class of lipids or a particular lipid, the total lipid extract can be fractionated into different groups of lipids, depending on the polarity of the compounds, by thin-layer chromatography (TLC) or by column chromatography. Thus, for example, to recover the neutral lipids (e.g., sterol esters and triacylglycerols) by column chromatography, the extract can be eluted with $\mathrm{CHCl}_{3}$, followed by acetone to elute the glycolipids and, finally, with $\mathrm{MeOH}$ to elute the phospholipids, as mentioned for the leaves, stems and fruit of Zygophyllum oxianum [59]. The majority of the studies on antimicrobial plant lipids obtained and analyzed FA and their derivatives. FA have been isolated from a series of plant parts by using $\mathrm{MeOH} /$ benzene/sulfuric acid, $85 \%$ ethanol or supercritical fluid extraction (SFE) with $\mathrm{CO}_{2}$ and analyzed as FAME [56,60-64].

Mixtures of FA and FAME were obtained, but it was not clear if these FA were found in the free or esterified forms, since the derivatization methods (methylation) used in these studies convert free and esterified FA to FAME. However, because of their high abundance, presumably, the referred FA were esterified to other lipids. Several oxylipins were retrieved from roots, stems, and leaves of Brazilian joyweed (Alternanthera brasiliana) by extracting with EtOH and EtOAc [65]. Acetylenic FA were isolated from the roots of Pentagonia gigantifolia with 95\% ethanol [38].

Other lipid classes isolated from plants for antimicrobial testing include sterols and sterol derivatives, glyceroglycolipids, and sphingolipids (Figure 2 and Table 1). The first group includes free sterols, steryl glycosides, and acyl steryl glycosides. Free sterols have been extracted together with triterpenes from the seeds of date palm (Phoenix dactylifera) by using $\mathrm{CHCl}_{3}$ and acetone [66], from several parts of Withania somnifera, Euphorbia hirta, and Terminalia chebula with EtOAc [67] and leaves of candle bush (Senna alata) and rhizomes of fingerroot (Kaempferia pandurata) with EtOH [68]. $\beta$-sitosterol 3-O- $\beta$-D-glucopyranoside, a steryl glycoside, was obtained from the leaves of Sendudok (Melastoma malabathricum) with $\mathrm{CHCl}_{3}$ /acetone/MeOH [69] and the acyl steryl glycosides sitosteryl 3- $\beta$-O-glucoside 6'-O-palmitate and stigmasteryl 3- $\beta$-O-glucoside 6'-O-palmitate were obtained from the roots of capotiraguá (Blutaparon portulacoides) with EtOH [70]. Glyceroglycolipids, namely sulfoquinovosyldiacylglycerols (SQDG) were retrieved from neem (Azadirachta indica) leaves by extracting with $\mathrm{MeOH}$ and separating by $\mathrm{SiO}_{2}$ column chromatography with $\mathrm{CHCl}_{3} / \mathrm{MeOH}$ [71] or extracted with petroleum ether and re-extracted with $\mathrm{MeOH}$ [72].

In the group of sphingolipids, different chemical structures were identified belonging to different subclasses: ceramides and glycosphingolipids, also known as cerebrosides (Figure 2 and Table 1). Artemceramide-B was identified from the roots of Artemisia incisa after extraction with $\mathrm{MeOH}$ and recovered by $\mathrm{SiO}_{2}$ column chromatography after elution of the extract with $\mathrm{CH}_{2} \mathrm{Cl}_{2} / \mathrm{MeOH}$ following previous elution with $n$-hexane/EtOAc [73]. A cerebroside (soya-cerebroside I), a sphingolipid glycoside (1-O- $\beta$-D-glucopyranosyl(2S,3S,4R,10E)-2-[(2'R)-2-hydroxytetracosanoylamino]-1,3,4-octadecanetriol10-ene), and its aglycone form $(2 S, 3 S, 4 R, 10 E)-2-\left[\left(2^{\prime} R\right)-2\right.$-hydroxytetra-cosanoylamino $]-1,3,4-$ octadecanetriol-10-ene) were isolated from the stems of cucumber (Cucumis sativus) by $\mathrm{CHCl}_{3}$ fractionation of the methanolic extract [74]. New glycosphingolipids were isolated and characterized from the fruits of fiddle leaf fig (Ficus pandurata), panduramides A-D and newbouldiamide [75], and from the woods of the giant-leaved fig (Ficus lutea), 1-O- $\beta$-D-glucopyranosyl-(2S,3R,5E,12E)$2 N-\left[\left(2^{\prime} R\right)\right.$-hydroxyhexadecanoyl]-octadecasphinga-5,12-dienine, commonly named lutaoside [76]. All these compounds are inhibitors of microbial growth, except panduramides A-D and newbouldiamide that did not reveal any activity (Table 2).

The fractionation of the extracts has been usually carried out by column chromatography and the purification of the compounds can be achieved by semi-preparative HPLC. 
Table 2. Antimicrobial activity of plant lipids or plant lipid-rich extracts.

\begin{tabular}{|c|c|c|c|c|c|c|}
\hline Botanical Name & Tested (Micro)Organisms & $\begin{array}{l}\text { Antimicrobial Testing } \\
\text { Method/Evaluation }\end{array}$ & $\begin{array}{c}\text { Reference } \\
\text { Antimicrobial } \\
\text { (Positive Control) }\end{array}$ & $\begin{array}{c}\text { MIC, MBC, Diameter } \\
\text { of Inhibition Zone (in } \\
\text { mm) or Other }\end{array}$ & $\begin{array}{l}\text { Isolated Lipids or } \\
\text { Lipid Mixtures }\end{array}$ & Ref. \\
\hline $\begin{array}{l}\text { Sesuvium } \\
\text { portulacastrum } \mathrm{L} .\end{array}$ & $\begin{array}{l}\text { G(+) bacteria: Bacillus subtilis } \\
\text { NCIM 2063, B. pumilus NCIM } \\
\text { 2327, Micrococcus luteus NCIM } \\
2376 \text { and S. aureus NCIM 2901; } \\
\text { G(-) bacteria: P. aeruginosa } \\
\text { NCIM 5031, K. pneumoniae } \\
\text { NCIM } 2957 \text { and E. coli NCIM } \\
\text { 2256. Ten isolates of MRSA and } \\
\text { of MRSA NCTC 6571. Human } \\
\text { pathogenic yeast type fungi: } \\
\text { Candida albicans, C. krusei, C. } \\
\text { tropicalis and C. parapsilosis and } \\
\text { mould fungi: Aspergillus niger, } \\
\text { A. flavus, and A. fumigatus }\end{array}$ & $\begin{array}{l}\text { Inhibition zone (IZ) by disk } \\
\text { diffusion test and minimum } \\
\text { inhibitory concentration } \\
\text { (MIC) by broth } \\
\text { macrodilution method }\end{array}$ & $\begin{array}{l}\text { Ciprofloxacin for } \\
\text { bacteria, methicillin, } \\
\text { oxacillin and } \\
\text { vancomycin for } \\
\text { MRSA and } \\
\text { amphotericin-B for } \\
\text { fungi }\end{array}$ & $\begin{array}{l}\text { MIC: } 0.25 \mathrm{mg} / \mathrm{mL} \text { for } B . \\
\text { subtilis, } 0.5 \mathrm{mg} / \mathrm{mL} \text { for } S \text {. } \\
\text { aureus, MRSA, } P \text {. } \\
\text { aeruginosa, } K \text {. } \\
\text { pneumoniae and C. } \\
\text { albicans, and } 1.0 \mathrm{mg} / \mathrm{mL} \\
\text { for } E . \text { coli; } \mathrm{MBC}: 0.5 \\
\mathrm{mg} / \mathrm{mL} \text { for } B . \text { subtilis, } \\
1.0 \mathrm{mg} / \mathrm{mL} \text { for } S . \text { aureus, } \\
\text { MRSA and K. } \\
\text { pneumoniae, and } 2.0 \\
\mathrm{mg} / \mathrm{mL} \text { for } P \text {. aeruginosa } \\
\text { and } E \text {. coli; MFC: } 1 \\
\mathrm{mg} / \mathrm{mL} \text { for } C \text {. albicans }\end{array}$ & FAME & [60] \\
\hline $\begin{array}{l}\text { Blutaparon } \\
\text { portulacoides (A. } \\
\text { St.-Hil.) Mears }\end{array}$ & $\begin{array}{c}\text { Trypanosoma cruzi, Leishmania } \\
\text { amazonensis, S. aureus ATCC } \\
25923 \text { and } 7+\text { penicillinase } \\
\text { producer, Streptococcus } \\
\text { epidermidis (6ep), E. coli ATCC } \\
\text { 10538, Streptococcus mutans } \\
(9.1), \text { Streptococcus sobrinus } \\
(180.3)\end{array}$ & $\begin{array}{l}\text { Crude extracts and isolated } \\
\text { compounds added to the } \\
\text { trypomastigote-containing } \\
\text { blood samples and } \\
\text { incubated } 24 \mathrm{~h} \text { at } 4{ }^{\circ} \mathrm{C} \text {. } \\
\text { Trypanocidal activity } \\
\text { evaluated by counting the } \\
\text { remaining trypomastigotes. } \\
\text { L. amazonensis amastigote } \\
\text { viability assessed } \\
\text { colorimetrically by the } \\
\text { reduction of a tetrazolium } \\
\text { salt (MTT). Antimicrobial } \\
\text { activity measured by the } \\
\text { well-diffusionmethod in } \\
\text { double layer }\end{array}$ & $\begin{array}{l}\text { Gentian violet for } \\
\text { trypanocidal activity } \\
\text { and gentamicin for } \\
\text { antibacterial assays }\end{array}$ & $\begin{array}{c}\text { MIC: } 100-500 \mu \mathrm{g} / \mathrm{mL} \text { in } \\
\text { T. cruzi trypomastigotes } \\
\text { and } 14-500 \mu \mathrm{g} / \mathrm{mL} \text { in } L . \\
\text { amazonensis } \\
\text { amastigotes; } 50 \mu \mathrm{g} / \mathrm{mL} \\
\text { in E. coli, S. aureus } \\
\text { ATCC } 25923, \text { S. aureus } \\
\text { (7+) and } 500 \mu \mathrm{g} / \mathrm{mL} \text { in } \\
\text { S. epidermidis, S. mutans, } \\
\text { and S. sobrinus }\end{array}$ & $\begin{array}{c}\text { Acyl steryl glycosides } \\
\text { (sitosteryl } \\
\text { 3- } \beta \text {-O-glucoside } \\
\text { 6'-O-palmitate and } \\
\text { stigmasteryl } \\
\text { 3- } \beta \text {-O-glucoside } \\
\text { 6'-O-palmitate) }\end{array}$ & [70] \\
\hline
\end{tabular}


Table 2. Cont.

\begin{tabular}{|c|c|c|c|c|c|c|}
\hline Botanical Name & Tested (Micro)Organisms & $\begin{array}{l}\text { Antimicrobial Testing } \\
\text { Method/Evaluation }\end{array}$ & $\begin{array}{c}\text { Reference } \\
\text { Antimicrobial } \\
\text { (Positive Control) }\end{array}$ & $\begin{array}{c}\text { MIC, MBC, Diameter } \\
\text { of Inhibition Zone (in } \\
\text { mm) or Other }\end{array}$ & $\begin{array}{l}\text { Isolated Lipids or } \\
\text { Lipid Mixtures }\end{array}$ & Ref. \\
\hline $\begin{array}{l}\text { Arthrocnemum indicum } \\
\text { (Willd.) Moq., } \\
\text { Salicornia brachiata } \\
\text { Roxb., Suaeda } \\
\text { maritima (L.) Dumort. } \\
\text { and Suaeda monoica } \\
\text { Forsk. }\end{array}$ & $\begin{array}{l}\text { G(+) bacteria: B. subtilis NCIM } \\
\text { 2063, B. pumilus NCIM 2327, M. } \\
\text { luteus NCIM 2376, and S. aureus } \\
\text { NCIM 2901; G(-) bacteria: P. } \\
\text { aeruginosa NCIM 5031, K. } \\
\text { pneumoniae NCIM 2957, and E. } \\
\text { coli NCIM 2256; ten isolates of } \\
\text { MRSA and of MRSA NCTC } \\
\text { 6571; yeasts (C. albicans, C. } \\
\text { krusei, C. tropicalis, and C. } \\
\text { parapsilosis) and molds (A. niger, } \\
\text { A. flavus, and A. fumigatus) }\end{array}$ & $\begin{array}{l}\text { Disk diffusion method and } \\
\text { broth macrodilution } \\
\text { method }\end{array}$ & $\begin{array}{l}\text { Ciprofloxacin for } \\
\text { bacteria, methicillin, } \\
\text { oxacillin and } \\
\text { vancomycin for } \\
\text { MRSA and } \\
\text { amphotericin-B for } \\
\text { fungi }\end{array}$ & $\begin{array}{l}\text { MIC of } 0.06 \mathrm{mg} / \mathrm{mL} \text { of } S . \\
\text { brachiata extracts } \\
\text { against } B . \text { subtilis, } S \text {. } \\
\text { aureus, and MRSA, and } \\
0.5 \mathrm{mg} / \mathrm{mL} \text { against } P . \\
\text { aeruginosa; MIC of } 0.5 \\
\text { mg/mL of all FAME } \\
\text { extracts against } E . \text { coli } \\
\text { and } K . \text { pneumoniae; } \\
\text { MBC of } 0.1 \mathrm{mg} / \mathrm{mL} \text { of } S . \\
\text { brachiata extracts } \\
\text { against } P . \text { aeruginosa } \\
\text { and of } 1.0 \mathrm{mg} / \mathrm{mL} \text { of all } \\
\text { FAME extracts against } \\
\text { E. coli and K. pneumoniae }\end{array}$ & FAME & [61] \\
\hline $\begin{array}{l}\text { Alternanthera } \\
\text { brasiliana }\end{array}$ & $\begin{array}{l}\text { E. coli ATCC 25922, B. subtilis } \\
\text { ATCC 6623, P. aeruginosa ATCC } \\
\text { 15442, M. luteus ATCC 9341, } \\
\text { and S. aureus ATCC } 25923\end{array}$ & $\begin{array}{l}\text { Microdilution broth } \\
\text { method according to } \\
\text { NCCLS standardization }\end{array}$ & $\begin{array}{l}\text { Tetracycline and } \\
\text { norfloxacin }\end{array}$ & $\begin{array}{l}\text { MIC: } 50 \mu \mathrm{g} / \mathrm{mL} \text { against } \\
\text { B. subtilis, M. luteus, and } \\
\text { S. aureus }\end{array}$ & Linoleate oxylipins & [65] \\
\hline Phoenix dactylifera $\mathrm{L}$. & Bacillus cereus and E. coli & Disk diffusion method & Streptomycin & $\begin{array}{c}20 \mathrm{~mm} \text { against } E . \text { coli } \\
\text { and } 17 \mathrm{~mm} \text { against } B . \\
\text { cereus at } 1 \mathrm{mg} / \mathrm{mL} \text { of the } \\
\text { acetone extract }\end{array}$ & Sterol and triterpenes & [66] \\
\hline $\begin{array}{c}\text { Asphodelus aestivus } \\
\text { Brot. }\end{array}$ & $\begin{array}{l}\text { G(+) bacteria: S. aureus ATCC } \\
\text { 6538-p, E. faecalis ATCC 29212; } \\
\text { G(-) bacteria: E. coli ATCC } \\
\text { 29998, K. pneumoniae ATCC } \\
\text { 13883, P. aeruginosa ATCC } \\
\text { 27853); yeasts: C. albicans } \\
\text { ATCC 10239 and C. krusei } \\
\text { ATCC } 6258\end{array}$ & $\begin{array}{l}\text { Disk diffusion method and } \\
\text { broth microdilution tests } \\
\text { according to the } \\
\text { recommendations of } \\
\text { Clinical and Laboratory } \\
\text { Standards Institute (CLSI) }\end{array}$ & $\begin{array}{l}\text { Ampicillin, } \\
\text { ciprofloxacin and } \\
\text { fluconazole }\end{array}$ & $\begin{array}{c}\text { MIC: } 512 \mu \mathrm{g} / \mathrm{mL} \text { against } \\
\text { S. aureus, E. faecalis, } K . \\
\text { pneumoniae, and } C . \\
\text { albicans }\end{array}$ & $\begin{array}{c}\text { FA (4:0, 6:0, 8:0, 10:0, } \\
\text { 16:0, 18:0, 21:0, 24:0, } \\
\text { 14:1, 15:1, 18:1n9t, } \\
\text { 20:1, 24:1, 18:2, } \\
\text { 18:2n6t, 18:2n6c, } \\
\text { 20:2n6, 20:3n3, 22:6n3, } \\
\text { and others } \\
\text { unidentified) }\end{array}$ & [54] \\
\hline
\end{tabular}


Table 2. Cont.

\begin{tabular}{|c|c|c|c|c|c|c|}
\hline Botanical Name & Tested (Micro)Organisms & $\begin{array}{l}\text { Antimicrobial Testing } \\
\text { Method/Evaluation }\end{array}$ & $\begin{array}{c}\text { Reference } \\
\text { Antimicrobial } \\
\text { (Positive Control) }\end{array}$ & $\begin{array}{c}\text { MIC, MBC, Diameter } \\
\text { of Inhibition Zone (in } \\
\text { mm) or Other }\end{array}$ & $\begin{array}{l}\text { Isolated Lipids or } \\
\text { Lipid Mixtures }\end{array}$ & Ref. \\
\hline Artemisia incisa Pamp. & S. epidermidis and S. aureus & $\begin{array}{l}\text { Agar well diffusion method } \\
\text { and MIC determined by a } \\
\text { referenced method }\end{array}$ & $\begin{array}{l}\text { Streptomycin and } \\
\text { tetracycline }\end{array}$ & $\begin{array}{c}\text { S. epidermidis }(0.0157 \\
\mathrm{mg} / \mathrm{mL}) \text { and S. aureus } \\
(0.0313 \mathrm{mg} / \mathrm{mL})\end{array}$ & Artemceramide-B & [73] \\
\hline $\begin{array}{l}\text { Pteranthus dichotomus } \\
\text { Forssk. (also known } \\
\text { as P. echinatus Desf.) }\end{array}$ & $\begin{array}{l}\text { S. aureus ATCC 25923, E. coli } \\
\text { ATCC 25922, K. pneumoniae } \\
\text { ESBL, and Enterobacter sp. ESBL }\end{array}$ & Disk diffusion method & $\begin{array}{l}\text { Gentamicin and } \\
\text { ampicillin }\end{array}$ & $\begin{array}{l}\text { P. dichotomus } \mathrm{BuOH} \\
\text { extracts at } 0.25 \mathrm{~g} / \mathrm{mL}(8 \\
\mathrm{mm} \text { against } E \text {. coli, } \mathrm{K} \text {. } \\
\text { pneumoniae } \mathrm{ESBL}) ; P \text {. } \\
\text { dichotomus } \mathrm{EtOAc} \\
\text { extract at } 0.5 \mathrm{~g} / \mathrm{mL}(7 \\
\mathrm{mm} \text { against } E . \text { coli }) \text {, at } \\
65 \mathrm{mg} / \mathrm{mL}(8.33 \mathrm{~mm} \\
\text { against } S . \text { aureus }) \text {, and } \\
\text { at } 0.25 \mathrm{~g} / \mathrm{mL}(7 \mathrm{~mm} \\
\text { against } \text { Enterobacter } s p \text {. } \\
\text { ESBL) }\end{array}$ & $\begin{array}{c}\text { BuOH fraction } \\
\text { contained } \\
\text { 1-O-palmitoyl- } \\
\text { 3-O-(6-sulfo- } \alpha \text {-D- } \\
\text { quinovopyranosyl)- } \\
\text { glycerol, 1,2-di-O- } \\
\text { palmitoyl-3-O- } \\
\text { (6-sulfo- } \alpha \text {-D- } \\
\text { quinovopyranosyl)- } \\
\text { glycerol and soya } \\
\text { cerebroside I. EtOAc } \\
\text { fraction contained } \\
\text { stigmat-7-en-3-ol, } \\
\text { spinasterol, } \\
\beta \text {-sitosterol and } \\
\beta \text {-sitosterol-3-O- } \\
\text { glucoside }\end{array}$ & [78] \\
\hline Cucumis satious L. & $\begin{array}{l}\text { Phytopathogenic fungi } \\
\text { (Pythium aphanidermatum, } \\
\text { Botryosphaeria dothidea, } \\
\text { Fusarium oxysporum f.sp. } \\
\text { cucumerinum, and Botrytis } \\
\text { cinerea); phytopathogenic } \\
\text { bacteria [G(-): Xanthomonas } \\
\text { vesicatoria ATCC 11633, } \\
\text { Pseudomonas lachrymans ATCC } \\
\text { 11921, and G(+) B. subtilis } \\
\text { ATCC } 11562 \text { ] }\end{array}$ & $\begin{array}{l}\text { Mycelial radial growth } \\
\text { inhibition assay and } \\
\text { antifungal activity (pour } \\
\text { plating method in potato } \\
\text { dextrose agar medium) for } \\
\text { fungi and agar-well } \\
\text { diffusion assay for bacteria }\end{array}$ & $\begin{array}{l}\text { Carbendazim for } \\
\text { fungi and } \\
\text { streptomycin sulfate } \\
\text { for bacteria }\end{array}$ & $\begin{array}{c}5.5-100 \text { inhibitory rate } \\
\text { of mycelia growth } \\
\text { inhibitory activity; } \mathrm{IC}_{50} \\
\text { of } B . \text { subtilis }(50.2-110.9 \\
\mu \mathrm{g} / \mathrm{mL}), X . \text { vesicatoria } \\
(25.6-64.5 \mu \mathrm{g} / \mathrm{mL}), P . \\
\text { lachrymans }(15.3-37.3 \\
\mu \mathrm{g} / \mathrm{mL}) \text { for } \\
\text { sphingolipids }\end{array}$ & $\begin{array}{c}\text { Sphingolipids } \\
{[(2 S, 3 S, 4 R, 10 E)-2-} \\
{\left[\left(2^{\prime} R\right)-2 \text {-hydroxy }\right.} \\
\text { tetracosanoylamino]- } \\
\text { 1,3,4-octadecanetriol- } \\
\text { 10-ene, } 1-O-\beta \text {-D- } \\
\text { glucopyranosyl- } \\
\text { (2S,3S,4R,10E)-2- } \\
{\left[\left(2^{\prime} R\right)-2 \text {-hydroxy }\right.} \\
\text { tetracosanoylamino]- } \\
\text { 1,3,4-octadecanetriol- } \\
\text { 10-ene and } \\
\text { soya-cerebroside I] }\end{array}$ & [74] \\
\hline
\end{tabular}


Table 2. Cont.

\begin{tabular}{|c|c|c|c|c|c|c|}
\hline Botanical Name & Tested (Micro)Organisms & $\begin{array}{l}\text { Antimicrobial Testing } \\
\text { Method/Evaluation }\end{array}$ & $\begin{array}{c}\text { Reference } \\
\text { Antimicrobial } \\
\text { (Positive Control) }\end{array}$ & $\begin{array}{c}\text { MIC, MBC, Diameter } \\
\text { of Inhibition Zone (in } \\
\text { mm) or Other }\end{array}$ & $\begin{array}{l}\text { Isolated Lipids or } \\
\text { Lipid Mixtures }\end{array}$ & Ref. \\
\hline Excoecaria agallocha & $\begin{array}{l}\text { G(+) bacteria: B. subtilis NCIM } \\
\text { 2063, B. pumilus NCIM 2327, M. } \\
\text { luteus NCIM 2376, S. aureus } \\
\text { NCIM 2901; G(-) bacteria: } P . \\
\text { aeruginosa NCIM 5031, K. } \\
\text { pneumoniae NICM 2957, and E. } \\
\text { coli NCIM 2256; yeasts: C. } \\
\text { albicans, C. krusei, C. tropicalis, } \\
\text { and C. parapsilosis }\end{array}$ & $\begin{array}{l}\text { Disk diffusion method for } \\
\text { antibacterial and antifungal } \\
\text { susceptibility tests; MIC } \\
\text { tested in Mueller-Hinton } \\
\text { broth for bacteria and yeast } \\
\text { nitrogen base for yeasts by } \\
\text { two-fold serial dilution } \\
\text { method }\end{array}$ & $\begin{array}{c}\text { Ciprofloxacin and } \\
\text { amphotericin B }\end{array}$ & $\begin{array}{l}\text { MIC: } 0.125 \mathrm{mg} \text { for } B . \\
\text { subtilis and S. aureus, } 0.5 \\
\text { mg for P. aeruginosa and } \\
\text { K. pneumoniae, and } 1.0 \\
\text { mg for E. coli; MBC: } \\
0.25 \mathrm{mg} \text { for B. subtilis } \\
\text { and S. aureus, } 1.0 \mathrm{mg} \text { for } \\
\text { P. aeruginosa and } \mathrm{K} \text {. } \\
\text { pneumoniae, and } 2.0 \mathrm{mg} \\
\text { for E. coli; MFC: } 1 \mathrm{mg} \\
\text { for C. albicans, C. krusei } \\
\text { and C. parapsilosis }\end{array}$ & FAME & [62] \\
\hline $\begin{array}{l}\text { Albizia adianthifolia } \\
\text { (Schumach) and } \\
\text { Pterocarpus angolensis } \\
\text { (DC) }\end{array}$ & $\begin{array}{c}\text { Bacteria (E. coli, P. aeruginosa, B. } \\
\text { subtilis, S. aureus) and yeast (C. } \\
\text { albicans) }\end{array}$ & $\begin{array}{l}\text { Modified agar overlay } \\
\text { method }\end{array}$ & $\begin{array}{l}\text { Chloramphenicol for } \\
\text { bacteria and } \\
\text { miconazole for fungi }\end{array}$ & $\begin{array}{l}\text { MIQ: } 1 \mu \mathrm{g} \text { of } n \text {-hexane } \\
\text { and } \mathrm{CHCl}_{3} \text { extracts of } \\
\text { A. adianthifolia against } E \text {. } \\
\text { coli; } 50 \mu \mathrm{g} \text { of } n \text {-hexane } \\
\text { and } \mathrm{CHCl}_{3} \text { extracts of } \\
\text { A. adianthifolia against } P \text {. } \\
\text { aeruginosa; } 50 \mu \mathrm{g} \text { of } \\
\mathrm{CHCl}_{3} \text { extract of } P \text {. } \\
\text { angolensis against } B \text {. } \\
\text { subtilis and } 100 \mu \mathrm{g} \text { of } \\
n \text {-hexane extract of } P \text {. } \\
\text { angolensis against } B \text {. } \\
\text { subtilis and C. albicans }\end{array}$ & $\begin{array}{l}n \text {-hexadecanoic acid } \\
\text { (palmitic acid); oleic } \\
\text { acid; chondrillasterol; } \\
\text { stigmasterol, } 24 S \\
5 \alpha \text {-stigmast-7-en-3-ol; } \\
\text { 9,12-octadecadienoic } \\
\text { acid (Z,Z)-, methyl } \\
\text { ester; } \\
\text { trans-13-octadecanoic } \\
\text { acid, methyl ester; } \\
\text { tetradecanoic acid; } \\
\text { hexadecanoic acid, } \\
\text { methyl ester; } \\
\text { octadecanoic acid }\end{array}$ & [79] \\
\hline Baphia massaiensis & $\begin{array}{l}\text { E. coli, B. subtilis, P. aeruginosa, } \\
\text { S. aureus, and C. albicans }\end{array}$ & Agar well diffusion method & Not mentioned & $\begin{array}{l}10 \mathrm{~mm} \text { of inhibition } \\
\text { zone against } E \text {. coli and } \\
\text { S. aureus, and } 16 \mathrm{~mm} \\
\text { against } B \text {. subtilis }\end{array}$ & Seed oil (total FA) & [80] \\
\hline
\end{tabular}


Table 2. Cont.

\begin{tabular}{|c|c|c|c|c|c|c|}
\hline Botanical Name & Tested (Micro)Organisms & $\begin{array}{l}\text { Antimicrobial Testing } \\
\text { Method/Evaluation }\end{array}$ & $\begin{array}{c}\text { Reference } \\
\text { Antimicrobial } \\
\text { (Positive Control) }\end{array}$ & $\begin{array}{c}\text { MIC, MBC, Diameter } \\
\text { of Inhibition Zone (in } \\
\text { mm) or Other }\end{array}$ & $\begin{array}{l}\text { Isolated Lipids or } \\
\text { Lipid Mixtures }\end{array}$ & Ref. \\
\hline $\begin{array}{l}\text { Cassia tora L. (or Senna } \\
\text { tora L. Roxb.) }\end{array}$ & $\begin{array}{c}\text { MRSA, MSSA, } B \text {. subtilis, and } P \text {. } \\
\text { aeruginosa }\end{array}$ & $\begin{array}{l}\text { Broth microdilution } \\
\text { method }\end{array}$ & Ampicillin & $\begin{array}{c}\text { MIC for all bacteria } \\
\text { between } 125-1000 \\
\mu \mathrm{g} / \mathrm{mL}\end{array}$ & $\begin{array}{l}\text { FA (the major were } \\
\text { palmitic acid, linoleic } \\
\text { acid, linolenic acid, } \\
\text { margaric acid, } \\
\text { melissic acid, and } \\
\text { behenic acid) }\end{array}$ & [55] \\
\hline $\begin{array}{c}\text { Quercus } \\
\text { leucotrichophora, A. } \\
\text { Camus }\end{array}$ & $\begin{array}{c}\mathrm{G}(+) \text { bacteria: } B . \text { subtilis and } S . \\
\text { aureus; } \mathrm{G}(-) \text { bacteria: } P . \\
\text { aeruginosa and } E . \text { coli }\end{array}$ & $\begin{array}{c}\text { Disk diffusion method for } \\
\text { antibacterial susceptibility } \\
\text { tests; MIC was tested in } \\
\text { Mueller-Hinton broth for } \\
\text { bacteria by two-fold serial } \\
\text { dilution method }\end{array}$ & Ciprofloxacin & $\begin{array}{l}\text { MIC: } 0.125 \mathrm{mg} / \mathrm{mL} \text { for } \\
\text { B. subtilis and S. aureus; } \\
0.5 \mathrm{mg} / \mathrm{mL} \text { for } P . \\
\text { aeruginosa and } 1.0 \\
\mathrm{mg} / \mathrm{mL} \text { for } E . \text { coli }\end{array}$ & FAME & [56] \\
\hline $\begin{array}{c}\text { Quercus } \\
\text { leucotrichophora A. } \\
\text { Camus }\end{array}$ & $\begin{array}{l}\text { G(-) bacteria: E. coli MTCC-582 } \\
\text { and P. aeruginosa MTCC-2295; } \\
\text { G(+) bacteria: S. aureus } \\
\text { MTCC-3160, B. subtilis } \\
\text { MTCC-441 and S. pyogenes } \\
\text { MTCC-1924 }\end{array}$ & Disk diffusion method & Ampicillin & $\begin{array}{l}\text { IZ of both extracts } \\
\quad \text { against all } \\
\text { microorganisms: } 8.53 \pm \\
0.50 \text { to } 19.07 \pm 0.31 \mathrm{~mm}\end{array}$ & $\begin{array}{c}\text { FA; linoleic acid in } \\
\text { stem bark and leaves } \\
\text { extracts and } \\
\text { cis-vaccenic acid in } \\
\text { stem bark }\end{array}$ & [81] \\
\hline $\begin{array}{l}\text { Vitex altissima L., } V . \\
\text { negundo L. and } V . \\
\text { trifolia } \mathrm{L} .\end{array}$ & $\begin{array}{l}\text { Culex quinquefasciatus (early } \\
\text { fourth-instar larvae) }\end{array}$ & $\begin{array}{c}\text { Larvicidal activity analyzed } \\
\text { according to standard } \\
\text { procedures (WHO-VBC } \\
81.807,1981)\end{array}$ & Not mentioned & $\begin{array}{c}\text { V. trifolia }\left(\mathrm{LC}_{50}=9.26\right. \\
\text { ppm and } \mathrm{LC}_{90}=21.28 \\
\text { ppm })\end{array}$ & FAME & [64] \\
\hline
\end{tabular}


Table 2. Cont.

\begin{tabular}{|c|c|c|c|c|c|c|}
\hline Botanical Name & Tested (Micro)Organisms & $\begin{array}{l}\text { Antimicrobial Testing } \\
\text { Method/Evaluation }\end{array}$ & $\begin{array}{c}\text { Reference } \\
\text { Antimicrobial } \\
\text { (Positive Control) }\end{array}$ & $\begin{array}{c}\text { MIC, MBC, Diameter } \\
\text { of Inhibition Zone (in } \\
\text { mm) or Other }\end{array}$ & $\begin{array}{l}\text { Isolated Lipids or } \\
\text { Lipid Mixtures }\end{array}$ & Ref. \\
\hline Linum usitatissimum L. & $\begin{array}{l}\text { A. flavus MTTC } 2799 \text { and A. } \\
\text { ochraceus CECT } 2092\end{array}$ & $\begin{array}{l}\text { Determination of percent } \\
\text { mycelial inhibition by } \\
\text { growth radial technique on } \\
\text { solid medium and by } \\
\text { biomass technique on } \\
\text { liquid medium }\end{array}$ & Not mentioned & $\begin{array}{l}\text { Antifungal index of } \\
\text { FAME in solid medium: } \\
54.19 \pm 0.85 \text { at } 10 \mu \mathrm{L} \text { in } \\
\text { A. flavus and } 40.48 \pm \\
0.12 \text { at } 90 \mu \mathrm{L} \text { for } A \text {. } \\
\text { ochraceus at } 90 \mu \mathrm{L}\end{array}$ & FAME & [57] \\
\hline $\begin{array}{c}\text { Azadirachta indica A. } \\
\text { Juss }\end{array}$ & $\begin{array}{l}\text { Multidrug-resistant clinical } \\
\text { isolates of S. aureus, Salmonella } \\
\text { enterica serovar typhi, S. } \\
\text { dysenteriae, E. coli, Vibrio } \\
\text { cholerae, K. pneumoniae, and } P . \\
\text { aeruginosa }\end{array}$ & $\begin{array}{l}\text { MIC determined by } \\
\text { microbroth dilution } \\
\text { method and antibacterial } \\
\text { sensitivity of SQDG } \\
\text { determined by disk } \\
\text { diffusion method (CLSI } \\
\text { protocol) }\end{array}$ & Not mentioned & $\begin{array}{l}\text { MIC of } 32 \mu \mathrm{g} / \mathrm{mL} \text { for } S \text {. } \\
\text { typhi and two isolates of } \\
S . d y s e n t e r i a e ; \text { MIC of } 64 \\
\mu \mathrm{g} / \mathrm{mL} \text { for three isolates } \\
\text { of } S . \text { typhi, E. coli and } V \text {. } \\
\text { cholerae and } 256 \mu \mathrm{g} / \mathrm{mL} \\
\text { for K. pneumoniae }\end{array}$ & SQDG & [71] \\
\hline $\begin{array}{c}\text { Azadirachta indica A. } \\
\text { Juss }\end{array}$ & $\begin{array}{l}\text { Raillietina spp. (helminth } \\
\text { parasite) }\end{array}$ & $\begin{array}{l}\text { Ultrastructural changes by } \\
\text { scanning electron } \\
\text { microscopy }\end{array}$ & Praziquantel & $\begin{array}{l}\text { Anthelmintic activity of } \\
\text { SQDG with } 0.5 \text { and } 1 \\
\mathrm{mg} / \mathrm{mL} \text {, respectively: } \\
\text { paralysis time of } 1 \mathrm{~h} \\
\text { and } 0.7 \mathrm{~h} \text {; death time of } \\
1.6 \mathrm{~h} \text { and } 0.9 \mathrm{~h}\end{array}$ & SQDG & [72] \\
\hline
\end{tabular}


Table 2. Cont.

\begin{tabular}{|c|c|c|c|c|c|c|}
\hline Botanical Name & Tested (Micro)Organisms & $\begin{array}{l}\text { Antimicrobial Testing } \\
\text { Method/Evaluation }\end{array}$ & $\begin{array}{c}\text { Reference } \\
\text { Antimicrobial } \\
\text { (Positive Control) }\end{array}$ & $\begin{array}{c}\text { MIC, MBC, Diameter } \\
\text { of Inhibition Zone (in } \\
\text { mm) or Other }\end{array}$ & $\begin{array}{l}\text { Isolated Lipids or } \\
\text { Lipid Mixtures }\end{array}$ & Ref. \\
\hline $\begin{array}{l}\text { Carapa guianensis and } \\
\text { Carapa vasquezii }\end{array}$ & $\begin{array}{l}\text { Phytopathogenic fungi: } A \text {. } \\
\text { flavus, A. niger, and } F . \\
\text { oxysporum }\end{array}$ & $\begin{array}{l}\text { Fungal mycelial growth } \\
\text { inhibition trials developed } \\
\text { in } 96 \text {-well microtiter plates } \\
\text { adding } 10 \mu \mathrm{L} \text { of conidia } \\
\text { suspensions }\left(2 \times 10^{5}\right. \\
\left.\text { conidia } \mathrm{mL}^{-1}\right) \text { and } 90 \mu \mathrm{L} \\
\text { yeast peptone dextrose. } \\
\text { Inhibition of germination } \\
\text { observed under light } \\
\text { microscopy }\end{array}$ & $\begin{array}{l}20 \text { mM hydrogen } \\
\text { peroxide }\end{array}$ & $\begin{array}{l}\text { MIC }(\mu \mathrm{g} / \mathrm{mL}): 125-250 \\
\text { of } C . \text { guianensis and } \\
15.6-125 \text { of } C . \text { vasquezii } \\
\text { against the three } \\
\text { phytopathogenic fungi }\end{array}$ & $\begin{array}{c}\text { FA, FAME, squalene, } \\
\beta \text {-sitosterol }\end{array}$ & [58] \\
\hline Ficus lutea Vahl & Mucor miehei and B. subtilis & Disk diffusion method & Nystatin & $\begin{array}{l}\text { IZ of } 17 \mathrm{~mm} \text { for } M \text {. } \\
\text { miehei; of } 16 \mathrm{~mm} \text { for } B \text {. } \\
\text { subtilis; and of } 12 \mathrm{~mm} \\
\text { for } C \text {. albicans exposed } \\
\text { to } 40 \mu \mathrm{g} \text { of compound }\end{array}$ & $\begin{array}{c}\text { Glycosphingolipid } \\
\text { [1-O- } \beta \text {-D-glucopyran } \\
\text { osyl-(2S,3R,5E,12E)- } \\
2 N-\left[\left(2^{\prime} R\right) \text {-hydroxy }\right. \\
\text { hexadecanoyl]- } \\
\text { octadecasphinga-5,12- } \\
\text { dienine] named } \\
\text { lutaoside }\end{array}$ & [76] \\
\hline Ficus pandurata Hance & $\begin{array}{l}\text { Yeast: C. albicans ATCC 90028, } \\
\text { C. glabrata ATCC 90030, C. } \\
\text { krusei ATCC 6258, A. fumigatus } \\
\text { ATCC 90906, MRSA ATCC } \\
\text { 33591, Cryptococcus neoformans } \\
\text { ATCC 90113, S. aureus ATCC } \\
\text { 2921, E. coli ATCC 35218, K. } \\
\text { pneumoniae ATCC 13883, P. } \\
\text { aeruginosa ATCC 27853, and } \\
\text { Mycobacterium intracellulare } \\
\text { ATCC 23068); chloroquine } \\
\text { sensitive (D6, Sierra Leone) } \\
\text { and resistant (W2, Indochina) } \\
\text { strains of Plasmodium } \\
\text { falciparum; parasite: Leishmania } \\
\text { donovani promastigotes }\end{array}$ & $\begin{array}{l}\text { Modified versions of the } \\
\text { NCCLS methods }\end{array}$ & $\begin{array}{l}\text { Antibacterial agent } \\
\text { and antifungal agents } \\
\text { not mentioned; } \\
\text { antimalarial agents: } \\
\text { chloroquine and } \\
\text { artemisinin; } \\
\text { anti-leishmanial } \\
\text { agents: pentamidine } \\
\text { and amphotericin B }\end{array}$ & $\begin{array}{l}\text { No activity was } \\
\text { observed for any } \\
\text { compound }\end{array}$ & $\begin{array}{c}\text { Ceramides } \\
\text { [panduramides A-D, } \\
\text { and newbouldiamide] }\end{array}$ & [75] \\
\hline
\end{tabular}


Table 2. Cont.

\begin{tabular}{|c|c|c|c|c|c|c|}
\hline Botanical Name & Tested (Micro)Organisms & $\begin{array}{l}\text { Antimicrobial Testing } \\
\text { Method/Evaluation }\end{array}$ & $\begin{array}{c}\text { Reference } \\
\text { Antimicrobial } \\
\text { (Positive Control) }\end{array}$ & $\begin{array}{c}\text { MIC, MBC, Diameter } \\
\text { of Inhibition Zone (in } \\
\text { mm) or Other }\end{array}$ & $\begin{array}{l}\text { Isolated Lipids or } \\
\text { Lipid Mixtures }\end{array}$ & Ref. \\
\hline $\begin{array}{l}\text { Kunzea ericoides (A. } \\
\text { Rich) J. Thompson }\end{array}$ & $\begin{array}{l}\text { E. coli ATCC } 25922 \text { and S. } \\
\text { aureus ATCC } 25923\end{array}$ & $\begin{array}{l}\text { Broth microdilution } \\
\text { method utilizing the redox } \\
\text { dye resazurin }\end{array}$ & Not mentioned & $\begin{array}{l}0.625-10 \mathrm{mg} / \mathrm{mL} \text { for } S \text {. } \\
\text { aureus and more than } 10 \\
\mathrm{mg} / \mathrm{mL} \text { in } E . \text { coli }\end{array}$ & $\begin{array}{c}\text { Steryl esters, } \\
\text { triacylglycerols, free } \\
\text { FA, sterols and } \\
\text { phospholipids }\end{array}$ & [77] \\
\hline $\begin{array}{l}\text { Pentagonia gigantifolia } \\
\text { Ducke }\end{array}$ & $\begin{array}{c}\text { C. albicans ATCC } 90028 \text { and } \\
\text { fluconazole-resistant C. albicans } \\
\text { strains }\end{array}$ & $\begin{array}{l}\text { MIC and MFC determined } \\
\text { by using a modified version } \\
\text { of the microdilution } \\
\text { NCCLS methods; } \\
\text { sphingolipid reversal assay }\end{array}$ & $\begin{array}{l}\text { Amphotericin B, } \\
\text { fluconazole and } \\
\text { flucytosine }\end{array}$ & $\begin{array}{l}\text { C. albicans ATCC } 90028 \\
\text { (0.52 to } 1.04 \mu \mathrm{g} / \mathrm{mL})\end{array}$ & $\begin{array}{c}\text { Acetylenic acids: } \\
\text { 6-octadecynoic acid } \\
\text { and 6-nonadecynoic } \\
\text { acid }\end{array}$ & [38] \\
\hline $\begin{array}{l}\text { Hedyotis pilulifera (Pit.) } \\
\text { T.N. Ninh }\end{array}$ & $\begin{array}{l}\text { S. aureus NBRC 100910, B. } \\
\text { subtilis NBRC 13719, M. } \\
\text { smegmatis NBRC } 13167\end{array}$ & Microdilution method & Ampicillin & $\begin{array}{c}\text { Oleanolic acid (MIC } \\
\text { value of } 2.5 \mu \mathrm{g} / \mathrm{mL} \\
\text { against } M . \text { smegmatis), } \\
\text { rotungenic acid (MIC } \\
\text { value of } 2.5,2.5 \text {, and } \\
1.25 \mu \mathrm{g} / \mathrm{mL} \text { against } S \text {. } \\
\text { aureus, B. subtilis, and } \\
M . \text { smegmatis, } \\
\text { respectively), rotundic } \\
\text { acid (MIC value of } 5 \\
\mu \mathrm{g} / \mathrm{mL} \text { against } B . \\
\text { subtilis) }\end{array}$ & $\begin{array}{c}\text { Triterpenoids, } \\
\text { steroids, FA, } \\
\text { glycolipids, and a } \\
\text { ceramide }\end{array}$ & [83] \\
\hline $\begin{array}{l}\text { Withania somnifera }(\mathrm{L} .) \\
\text { Dunal, Euphorbia hirta } \\
\text { L., Terminalia chebula } \\
\text { Retz. }\end{array}$ & $\begin{array}{l}\text { E. coli MTCC 46, P. aeruginosa } \\
\text { MTCC 1934), Proteus mirabilis } \\
\text { MTCC 3310, Raoultella } \\
\text { planticola MTCC 2271, } \\
\text { Enterobacter aerogenes (now } \\
\text { Klebsiella aerogenes) MTCC 2822, } \\
\text { B. subtilis MTCC 121, S. aureus } \\
\text { MTCC } 3160\end{array}$ & $\begin{array}{l}\text { Disk diffusion method for } \\
\text { antibiotic susceptibility } \\
\text { testing. Broth } \\
\text { microdilution method for } \\
\text { determination of MIC } \\
\text { values }\end{array}$ & Streptomycin & $\begin{array}{c}\text { MIC: } W \text {. somnifera leaf } \\
\text { (0.039 } \mathrm{mg} / \mathrm{mL} \text { on } P . \\
\text { aeruginosa); } T \text {. chebula } \\
\text { fruits and stems }(0.039 \\
\mathrm{mg} / \mathrm{mL} \text { on } E \text {. coli) and } T \text {. } \\
\text { chebula stems and fruits } \\
(0.039 \mathrm{mg} / \mathrm{mL} \text { on } S . \\
\text { aureus): MBC of } 0.039 \\
\mathrm{mg} / \mathrm{mL} \text { of } T \text {. chebula } \\
\text { bark on } S \text {. aureus }\end{array}$ & Sterols fraction & [67] \\
\hline
\end{tabular}


Table 2. Cont.

\begin{tabular}{|c|c|c|c|c|c|c|}
\hline Botanical Name & Tested (Micro)Organisms & $\begin{array}{l}\text { Antimicrobial Testing } \\
\text { Method/Evaluation }\end{array}$ & $\begin{array}{c}\text { Reference } \\
\text { Antimicrobial } \\
\text { (Positive Control) }\end{array}$ & $\begin{array}{c}\text { MIC, MBC, Diameter } \\
\text { of Inhibition Zone (in } \\
\text { mm) or Other }\end{array}$ & $\begin{array}{l}\text { Isolated Lipids or } \\
\text { Lipid Mixtures }\end{array}$ & Ref. \\
\hline $\begin{array}{l}\text { Kaempferia pandurata } \\
\text { Roxb. (synonym of } \\
\text { Boesenbergia rotunda } \\
\text { (L.) Mansf.) and } \\
\text { Senna alata (L.) Roxb. }\end{array}$ & $\begin{array}{l}\text { MRSA, extended spectrum } \\
\text { beta-lactamase (ESBL), and } \\
\text { carbapenemase-resistant } \\
\text { Enterobacteriaceae (CRE) }\end{array}$ & $\begin{array}{l}\text { Broth microdilution } \\
\text { method }\end{array}$ & $\begin{array}{l}\text { Tetracycline and } \\
\text { vancomycin for } \\
\text { MRSA, cefotaxime } \\
\text { and meropenem for } \\
\text { ESBL-producing } \\
\text { bacteria and for CRE }\end{array}$ & $\begin{array}{l}\text { MIC: } \text { K. pandurata } \\
\text { extract }(256 \mu \mathrm{g} / \mathrm{mL}) \text { and } \\
\text { S. alata extract (512 } \\
\mu \mathrm{g} / \mathrm{mL}) \text { against MRSA }\end{array}$ & $\begin{array}{l}\text { Sterols and } \\
\text { triterpenoid }\end{array}$ & [68] \\
\hline
\end{tabular}

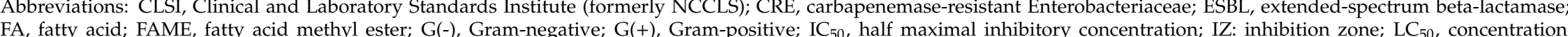
(ppm) at which $50 \%$ of larvae showed mortality; LC 90 , concentration (ppm) at which $90 \%$ of larvae showed mortality; MBC, minimum bactericidal concentration; MFC, minimum fungicidal concentration; MIC, minimum inhibitory concentration; MIQ, minimum inhibition quantity; MRSA, methicillin-resistant Staphylococcus aureus; MSSA, methicillin-sensitive Staphylococcus aureus; MTT, 3-(4,5-dimethylthiazol-2-yl)-2,5-diphenyltetrazolium bromide (tetrazolium dye); NCCLS, National Committee for Clinical Laboratory Standards; ppm, parts per million; SQDG, sulfoquinovosyldiacylglycerol. 
Different analytical platforms have been used to identify and characterize the structure of lipids in plant extracts. Generally, in natural products research, several complementary methods are used, such as ${ }^{1} \mathrm{H}$ and ${ }^{13} \mathrm{C}$ nuclear magnetic resonance (NMR) spectroscopy, gas chromatography (GC) coupled to a flame ionization detector (GC-FID) or to a mass spectrometer (GC-MS), as well as MS with electrospray ionization (ESI-MS). Liquid chromatography-MS (LC-MS) and LC-MS/MS has not been much used on antimicrobial plant lipids' research, only for sphingolipids analysis [74] and for linoleate oxylipins' structural characterization [65]. Besides these common techniques, two-dimensional NMR techniques (2-D NMR such as correlation spectroscopy-COSY, nuclear Overhauser effect spectroscopy-NOESY, heteronuclear single quantum coherence-HSQC, and heteronuclear multiple bond correlation-HMBC) have been used for the identification of artemceramide-D [73] and glyceroglycolipids [72]. Other methods are regularly used for the analysis of lipid extracts or their fractionation, such as TLC $[57,69,74,77]$, column chromatography as mentioned above, or paper chromatography, but the information is very limited [69]. Analysis of FA is mostly performed by GC-FID or GC-MS, after derivatization. Total lipid extracts or lipid fractions are subjected to derivatization techniques using acid or alkaline hydrolysis or transmethylation to obtain FAME.

To identify and/or quantify mixtures of compounds, simpler techniques can be applied as biochemical assays using colorimetric tests, as for instance, for sterols' and steryl glycosides' identification and quantification $[68,69,72]$. The data obtained for compounds' identification in these studies on antimicrobial plant lipids are normally compared with data reported in the literature, especially for spectroscopic data $[72,83]$.

\subsection{Susceptibility Testing, Inhibitory, and Microbicidal Activities of Plant Lipids}

Several microbial strains were used in plant lipid studies, comprising Gram-positive bacteria, Gram-negative bacteria, acid-fast bacteria, yeasts, filamentous fungi, parasitic protozoa, and some MDR strains and/or hospital isolated strains, such as MRSA (Table 2).

The lowest MIC against $S$. aureus were observed for the mixture of lipid classes from the aerial parts of Hedyotis pilulifera $(1.25 \mu \mathrm{g} / \mathrm{mL})$ [83], the artemceramide-B from the roots of $A$. incisa $(0.0313 \mathrm{mg} / \mathrm{mL})$ [73], the linoleate oxylipins isolated from Alternanthera brasiliana $(50 \mu \mathrm{g} / \mathrm{mL})$ [65], and the FAME extracted from the shoots of Salicornia brachiata $(60 \mu \mathrm{g} / \mathrm{mL}$, the same MIC also verified for a MRSA strain) [61]. In the case of artemceramide-B, its high inhibitory potential against $S$. aureus was assigned to this polar lipid bearing four hydroxyl groups and an amide linkage between two long aliphatic chains [73]. In the case of the linoleate oxylipins from A. brasiliana plant tissues, five isolated oxylipins were also found to be synthesized by endophytic Bacillus strains isolated from this plant. So, it was speculated that the antimicrobial activity of the oxylipins from this plant could be derived from the endophytic bacteria, supposing an ecological crosstalk between this plant and its endogenous microbiome [65]. Also, the LC-MS/MS approach was crucial to identify these antimicrobial compounds both in the plants and in the bacteria, shedding some light on the plant-bacteria interplay [65].

The FA from the extract of Cassia tora's leaves and stems exhibited MIC between 200 and $1000 \mu \mathrm{g} / \mathrm{mL}$ against MRSA [55]. The minimum bactericidal concentrations (MBC) against MRSA were determined on FAME from the leaves of Excoecaria agallocha (0.25 mg against $S$. aureus) [62], for MRSA the leaves of Sesuvium portulacastrum $(1.0 \mathrm{mg} / \mathrm{mL})$ [79], and the hexadecanoate methyl and hexadecanoic acid $<n->$ obtained from the stem bark of Scaphium macropodum (3.13 mg/mL against S. aureus) [82].

Other studies have tested the antimicrobial activity of lipids against other pathogenic microorganisms of great relevance for the clinical area and included in WHO's guidelines, such as those of the "ESKAPE" group. The lipid extracts with greater inhibiting capacity over Escherichia coli were the FA and their derivatives from $n$-hexane and $\mathrm{CHCl}_{3}$ extracts of the heartwood of $A$. adianthifolia $(1 \mu \mathrm{g})$ [79], and the acyl steryl glycosides obtained from roots of B. portulacoides $(50 \mu \mathrm{g} / \mathrm{mL})$ [70]. Also with low MIC values, the FAME extracted from the shoots of $S$. brachiata $(0.5 \mathrm{mg} / \mathrm{mL})[61]$ and the FAME and steroids from Trigonella foenum-graecum seeds (100 $\mu \mathrm{g} / \mathrm{mL})$ [63]. A MBC range between 1.0 and $2.0 \mathrm{mg} / \mathrm{mL}$ was verified for FAME extracts from the leaves of different plants [60-62]. 
Some lipid extracts were found to have low MIC against $P$. aeruginosa, as the FA and their derivatives obtained from the $n$-hexane and $\mathrm{CHCl}_{3}$ extracts of the heartwood of $A$. adianthifolia $(50 \mu \mathrm{g})$ [79], FAME and steroids from fenugreek seeds (T. foenum-graecum, $100 \mu \mathrm{g} / \mathrm{mL}$ ) [63], and the SQDG extracted from the neem leaves (A. indica, $128 \mu \mathrm{g} / \mathrm{mL}$ ) [71]. MBC toward P. aeruginosa between 0.1 and $2.0 \mathrm{mg} / \mathrm{mL}$ were verified for the extracts of FAME from leaves of different plants [60-62], similarly to the findings for the E. coli strains.

For strains of Salmonella typhimurium, a high MIC value of $25 \mathrm{mg} / \mathrm{mL}$ was obtained from the stem bark extract of $S$. macropodum which contained four compounds including two FA (hexadecanoate methyl and hexadecanoic acid $<n->)$ [82]. The SQDG extracted from the neem leaves showed antimicrobial activity against MDR strains of Salmonella typhi and Shigella dysenteriae, both with a MIC range between 32 and $64 \mu \mathrm{g} / \mathrm{mL}$, and also against MDR strains of E. coli $(64-128 \mu \mathrm{g} / \mathrm{mL})$, P. aeruginosa $(128 \mu \mathrm{g} / \mathrm{mL})$, S. aureus $(128-256 \mu \mathrm{g} / \mathrm{mL})$, and K. pneumoniae $(256 \mu \mathrm{g} / \mathrm{mL})$ [71]. Also, identical MIC values $(0.5 \mathrm{mg} / \mathrm{mL})$ of FAME extracts [60-62] and FA [54] from different plants were observed against $K$. pneumoniae.

Studies with Mycobacterium sp. demonstrated antimicrobial activity of extracts of fenugreek seeds that contained a mixture of FAME and steroids, having a MIC of $100 \mu \mathrm{g} / \mathrm{mL}$ against $M$. tuberculosis [63]. Activity against Mycobacterium smegmatis was also verified by extracts containing hexadecanoate methyl and hexadecanoic acid $<n->$ FA from the stem bark of Malva nut, S. macropodum $(3.13 \mathrm{mg} / \mathrm{mL})$ and a MBC of $6.25 \mathrm{mg} / \mathrm{mL}$ [82]. Finally, the triterpenoids oleanolic acid and rotungenic acid were found to have activity against M. smegmatis with a MIC of $2.5 \mu \mathrm{g} / \mathrm{mL}$ and $1.25 \mu \mathrm{g} / \mathrm{mL}$, respectively [83].

The fenugreek seed extracts from which conjugated linoleic acid methyl ester, saturated FAME, and steroids were identified, showed an inhibitory effect against Plasmodium falciparum with a MIC of $0.29 \mu \mathrm{g} / \mathrm{mL}[63]$.

The glycolipid SQDG isolated from neem has a broad-spectrum of activity against MDR bacterial strains [71] and anti-helminthic activity [72], which proves to be a promising natural antimicrobial agent. This class of compounds isolated from neem has demonstrated antiviral activity (herpes simplex viruses, HSV-1 and HSV-2) [71], significant DNA binding properties [84], and anti-leukemic activity [85]. However, it is difficult to isolate a single compound or a class of compounds from complex matrices as plants. In most studies, the antimicrobial effects may be due to a synergistic effect between several natural antimicrobial compounds, and not just to the referred lipids. As such, more studies must be done to understand which lipids can effectively be responsible by the inhibitory or microbicidal effect and the structure-activity relationship.

\section{Antimicrobial Lipids from Marine Organisms}

The most studied antimicrobial compounds of marine origin are peptides and alkaloids [86-88], contrarily to lipids. However, lipids are ubiquitously distributed in the different marine phyla, being quite abundant in some of them. Besides, several lipid classes from marine organisms have been recognized by their biological activity with a high potential to discover new antimicrobial compounds.

\subsection{Marine Algae}

Algal biomass is mainly composed by minerals, sugars, proteins, and lipids, that represent $1-15 \%$, depending on the algal species and its habitat. Lipids found in the macroalgae from the three phyla, Rhodophyta, Chlorophyta, and Ochrophyta (Table 3), have demonstrated antimicrobial activity against Gram-positive and Gram-negative bacteria, yeasts, and fungi [29,89-92] (Table 4). Most of these antimicrobial lipids were isolated from Rhodophyta and Chlorophyta. While the former shows a high diversity of algal species as source of antimicrobial lipids, studies in Chlorophyta were focused on species belonging to the order Bryopsidales. 
Table 3. Algae lipids and lipid-rich extracts with antimicrobial potential, their origin and extraction method.

\begin{tabular}{|c|c|c|c|c|c|}
\hline Scientific Name & Collection Site & Extracting Solvent(s)/Method & $\begin{array}{l}\text { Isolated Lipids or Lipid } \\
\text { Classes }\end{array}$ & $\begin{array}{l}\text { Methods for Compounds } \\
\text { Identification }\end{array}$ & Ref. \\
\hline \multicolumn{6}{|c|}{ Macroalgae-Chlorophyta } \\
\hline Caulerpa racemosa & Qionghai, Hainan, China & $\begin{array}{l}\text { EtOH }(95 \%) \text {. Extract partitioned } \\
\text { with EtOAc and } n-\mathrm{BuOH}\end{array}$ & $\begin{array}{c}\text { SQDG } \\
\text { [2S-1,2-di-O-palmitoyl-3- } \\
\text { O-(6'sulfo- } \alpha \text {-D- } \\
\text { quinovopyranosyl) } \\
\text { glycerol] }\end{array}$ & ${ }^{1} \mathrm{H}$ and ${ }^{13} \mathrm{C}$ NMR, ESI-MS & [95] \\
\hline $\begin{array}{l}\text { Caulerpa racemosa, } \\
\text { Caulerpa lentillifera }\end{array}$ & Port Dickson, Malaysia & $\mathrm{CHCl}_{3}, \mathrm{MeOH}$ & PUFA, MUFA, Terpenoids & LC-MS & [96] \\
\hline $\begin{array}{c}\text { Caulerpa racemosa, Ulva } \\
\text { fasciata }\end{array}$ & $\begin{array}{l}\text { Buzios, Rio de Janeiro, } \\
\text { Brazil }\end{array}$ & $\begin{array}{c}\text { Acetone insoluble material } \\
\text { extracted with } \mathrm{CHCl}_{3} / \mathrm{MeOH}(2: 1 \\
\text { and } 1: 2, v / v) . \mathrm{Lipid}_{\text {extract }} \\
\text { partitioned on } \mathrm{SiO}_{2} \text { column, } \\
\text { eluted with } \mathrm{CHCl}_{3} \text {, acetone or } \\
\mathrm{MeOH}\end{array}$ & $\begin{array}{l}\text { Glycolipid-rich extracts } \\
\text { (Sulfoglycolipids, } \\
\text { Glycosyldiacylglycerols) }\end{array}$ & HPTLC & [97] \\
\hline $\begin{array}{l}\text { Caulerpa spp., Chlorodesmis } \\
\text { fastigiata, Halimeda spp., } \\
\text { Penicillus capitatus, } \\
\text { Penicillus dumentosus, } \\
\text { Penicillus pyriformis, } \\
\text { Rhipocephalus phoenix, } \\
\text { Udotea argentea, Udotea } \\
\text { cyathiformis, Udotea } \\
\text { flabellum, Udotea petiolata }\end{array}$ & $\begin{array}{c}\text { Bahamas, Florida Keys, } \\
\text { Puerto Rico, Belize, Guan, } \\
\text { Hawaii, Australia, } \\
\text { Mediterranean Sea }\end{array}$ & $\begin{array}{c}\mathrm{CH}_{2} \mathrm{Cl}_{2} \text {. Chlorophylls removed } \\
\text { with } \mathrm{MgO}_{3} \mathrm{Si} \text {. Fractionation with } \\
\mathrm{SiO}_{2} \text { column and purification by } \\
\text { HPLC }\end{array}$ & $\begin{array}{l}\text { Sequiterpenoids, } \\
\text { Diterpenoids }\end{array}$ & TLC, NMR, HPLC & [98] \\
\hline Chaetomorpha linum & $\begin{array}{l}\text { IMTA, Mar Piccolo of } \\
\text { Taranto, Italy }\end{array}$ & $\begin{array}{c}\mathrm{CHCl}_{3} / \mathrm{MeOH}(2: 1, v / v), \text { Soxhlet } \\
\text { extractor, EtOH }(95 \%)\end{array}$ & Lipid extracts & $\begin{array}{l}{ }^{1} \mathrm{H} \text { and }{ }^{13} \mathrm{C} \text { NMR, } 1 \mathrm{D} \text { and } \\
\text { 2D NMR, GC-FID, TLC }\end{array}$ & [99] \\
\hline Codium amplivesiculatum & Bahía Magdalena, Mexico & $\begin{array}{c}\mathrm{CH}_{2} \mathrm{Cl}_{2} / \mathrm{EtOH}(97: 3, v / v) . \\
\mathrm{Liquid} / \text { liquid extraction } \\
\mathrm{CH}_{2} \mathrm{Cl}_{2} / \mathrm{H}_{2} \mathrm{O} \text {. Fractionation with } \\
\mathrm{CH}_{2} \mathrm{Cl}_{2} \text {. Crystallization in hot } \\
\text { MeOH }\end{array}$ & $\begin{array}{l}\text { Fraction with clerosterol } \\
\text { as main constituent. } \\
\text { Isolated clerosterol did } \\
\text { not show activity }\end{array}$ & ${ }^{1} \mathrm{H}$ NMR, IR & {$[100]$} \\
\hline
\end{tabular}


Table 3. Cont

\begin{tabular}{|c|c|c|c|c|c|}
\hline Scientific Name & Collection Site & Extracting Solvent(s)/Method & $\begin{array}{l}\text { Isolated Lipids or Lipid } \\
\text { Classes }\end{array}$ & $\begin{array}{l}\text { Methods for Compounds } \\
\text { Identification }\end{array}$ & Ref. \\
\hline \multirow{4}{*}{ Ulva fasciata } & Malvan, India & $\begin{array}{c}\text { EtOH, fractionated by neutral } \\
\text { alumina column with } \\
\text { EtOAc/MeOH }\end{array}$ & $\begin{array}{c}\text { Sphingosine (major } \\
\text { component: } \\
N \text {-palmitoyl-2- } \\
\text { amino-1,3,4,5- } \\
\text { tetrahydroxyoctadecane) }\end{array}$ & $\begin{array}{c}{ }^{1} \mathrm{H} \text { and }{ }^{13} \mathrm{C} \text { NMR, } \\
\text { FAB-MS, IR }\end{array}$ & [101] \\
\hline & Malvan, India & $\begin{array}{c}\text { EtOH }(90 \%) \text {. Extract fractionated. } \\
n \text {-hexane fraction } \\
\text { chromatographed on } \mathrm{SiO}_{2} \text { and } \\
\text { flash } \mathrm{SiO}_{2}\end{array}$ & $\begin{array}{l}\text { Ceramide } \\
\text { (Erythro-sphinga-4,8- } \\
\text { dienine- } N \text {-palmitate) }\end{array}$ & $\begin{array}{c}{ }^{1} \mathrm{H} \text { and }{ }^{13} \mathrm{C} \text { NMR, ESI-MS, } \\
\text { GC-MS, IR }\end{array}$ & [102] \\
\hline & Mediterranean Sea, Egypt & $\begin{array}{c}\mathrm{CHCl}_{3} / \mathrm{MeOH}(2: 1, v / v) . \\
\text { Glycolipid separation using } \\
\text { acetone on } \mathrm{SiO}_{2} \text { column }\end{array}$ & $\begin{array}{l}\text { Glycolipid-rich extracts } \\
\text { (DGDG) }\end{array}$ & GC-FID, LC-MS/MS & [103] \\
\hline & Mediterranean Sea, Egypt & $\begin{array}{c}\mathrm{MeOH} / \mathrm{CHCl}_{3}(2: 1, v / v) . \\
\text { Sulfolipid isolation: } \\
\text { diethylaminoethyl-cellulose } \\
\text { column eluted with } \\
\mathrm{CHCl}_{3} / \mathrm{MeOH}(6: 4, v / v) \text { and } \mathrm{NH}_{3}\end{array}$ & Sulfolipids (SQDG) & $\begin{array}{l}\text { GC-MS, GC-FID, } \\
\text { LC-MS/MS, IR }\end{array}$ & [89] \\
\hline Ulva rigida & $\begin{array}{c}\text { Cap Zebib and Ghar El } \\
\text { Melh, Tunisia }\end{array}$ & $\begin{array}{c}\mathrm{CH}_{2} \mathrm{Cl}_{2} \text { and } \mathrm{CH}_{2} \mathrm{Cl}_{2} / \mathrm{MeOH}(1: 1, \\
v / v) . \text { Extracts fractionated on } \\
\mathrm{SiO}_{2} \text { column and TLC with } \\
n \text {-hexane/EtOAc/CH}{ }_{2} \mathrm{Cl}_{2} / \mathrm{MeOH}\end{array}$ & FA & ${ }^{1} \mathrm{H}$ and ${ }^{13} \mathrm{C}$ NMR, GC & [27] \\
\hline \multicolumn{6}{|c|}{ Macroalgae-Rhodophyta } \\
\hline Chondria armata & $\begin{array}{l}\text { Goa, West coast of India; } \\
\text { Mumbai, India }\end{array}$ & $\begin{array}{c}\mathrm{MeOH} \text { and } \mathrm{CHCl}_{3}, \text { Polar } \\
\text { fractions: petroleum ether/EtOAc } \\
(1: 1, v / v), \mathrm{MeOH} \mathrm{CHCl}_{3}(2: 98 \\
v / v), \mathrm{MeOH} / \mathrm{CHCl}_{3}(5: 95, v / v)\end{array}$ & $\begin{array}{l}\text { Neutral glycolipids [main } \\
\text { compound } \\
\text { MGDG(20:5/16:0)] }\end{array}$ & $\begin{array}{c}{ }^{1} \mathrm{H} \text { and }{ }^{13} \mathrm{C} \text { NMR, } \\
\text { ESI-MS/MS }\end{array}$ & [104] \\
\hline $\begin{array}{l}\text { Chondrus crispus, } \\
\text { Gracilaria vermiculophylla, } \\
\text { Porphyra dioica }\end{array}$ & $\begin{array}{l}\text { IMTA and Portuguese } \\
\text { coast, Portugal }\end{array}$ & EtOAc in Soxhlet extractor & FA & GC-FID & [105] \\
\hline
\end{tabular}


Table 3. Cont.

\begin{tabular}{|c|c|c|c|c|c|}
\hline Scientific Name & Collection Site & Extracting Solvent(s)/Method & $\begin{array}{c}\text { Isolated Lipids or Lipid } \\
\text { Classes }\end{array}$ & $\begin{array}{l}\text { Methods for Compounds } \\
\text { Identification }\end{array}$ & Ref. \\
\hline $\begin{array}{c}\text { Falkenbergia } \\
\text { (heteromorphic } \\
\text { sporophyte of } \\
\text { Asparagopsis taxiformis) }\end{array}$ & Kollam coast, India & $\begin{array}{c}\mathrm{MeOH} \text {. Fractionation on } \mathrm{SiO}_{2} \\
\text { column (petroleum ether/EtOAc } \\
\text { and EtOAc/MeOH). Purification } \\
\text { with TLC and RP HPLC }\end{array}$ & FA & GC-MS & [106] \\
\hline \multirow[b]{2}{*}{$\begin{array}{l}\text { Galaxaura cylindrica, } \\
\text { Laurencia papillosa }\end{array}$} & Red Sea, Egypt & $\begin{array}{c}\mathrm{CHCl}_{3} / \mathrm{MeOH}(2: 1, v / v) . \\
\text { Glycolipid separation using } \\
\text { acetone on } \mathrm{SiO}_{2} \text { columns }\end{array}$ & $\begin{array}{l}\text { Glycolipid-rich extracts } \\
\text { (DGDG) }\end{array}$ & LC-MS/MS & [103] \\
\hline & Red Sea, Egypt & $\begin{array}{c}\mathrm{MeOH} / \mathrm{CHCl}_{3}(2: 1, v / v) . \\
\text { Sulfolipid isolation: } \\
\text { diethylaminoethyl-cellulose } \\
\text { column }\left(\mathrm{CHCl}_{3} / \mathrm{MeOH}(6: 4, v / v)\right. \\
\left.\text { and } \mathrm{NH}_{3}\right)\end{array}$ & Sulfolipids (SQDG) & $\begin{array}{l}\text { GC-MS, GC-FID, } \\
\text { LC-MS/MS, IR }\end{array}$ & [89] \\
\hline Gigartina tenella & $\begin{array}{c}\text { Sagami Bay, Kanagawa, } \\
\text { Japan }\end{array}$ & $\begin{array}{l}\text { Acetone. Extract partitioned with } \\
\text { EtOAc/ } \mathrm{H}_{2} \mathrm{O}(3: 1, v / v) \text {. Organic } \\
\text { layer dissolved in } \\
\text { EtOAc/MeOH/H } \mathrm{H}_{2} \mathrm{O}(100: 20: 5, v / v) \\
\text { and chromatographed on } \mathrm{SiO}_{2} \\
\text { column }\end{array}$ & Glycolipid (Sulfolipids) & $\begin{array}{c}{ }^{1} \mathrm{H} \text { and }{ }^{13} \mathrm{C} \text { NMR, } \\
\text { HR-FAB-MS }\end{array}$ & [107] \\
\hline Gracilaria gracilis & $\begin{array}{l}\text { Ganzirri lagoon and } \\
\text { Margi channel, Eastern } \\
\text { Sicily, Italy }\end{array}$ & $\mathrm{CHCl}_{3}, \mathrm{Et}_{2} \mathrm{O}$ in Soxhlet extractor & FA & GC-FID & [94] \\
\hline Gracilariopsis longissima & $\begin{array}{l}\text { Mar Piccolo of Taranto, } \\
\text { Italy }\end{array}$ & $\mathrm{CHCl}_{3} / \mathrm{MeOH} / \mathrm{H}_{2} \mathrm{O}(2: 1: 1, v / v)$ & FA & $\begin{array}{c}{ }^{1} \mathrm{H} \text { and }{ }^{13} \mathrm{C} \text { NMR, } 1 \mathrm{D} \text { and } \\
\text { 2D NMR, GC-FID }\end{array}$ & [108] \\
\hline $\begin{array}{l}\text { Hypnea musciformis, } \\
\text { Osmundaria obtusiloba, } \\
\text { Porphyra acanthophora, } \\
\text { Pterocladiella capillacea }\end{array}$ & $\begin{array}{l}\text { Buzios, Rio de Janeiro, } \\
\text { Brazil }\end{array}$ & $\begin{array}{c}\text { Acetone insoluble material } \\
\text { extracted with } \mathrm{CHCl}_{3} / \mathrm{MeOH}(2: 1 \\
\text { and } 1: 2, v / v) \text {. Extract partitioned } \\
\text { on } \mathrm{SiO}_{2} \text { column }\left(\mathrm{CHCl} l_{3} \text {, acetone }\right. \\
\text { or } \mathrm{MeOH})\end{array}$ & $\begin{array}{l}\text { Glycolipid-rich extracts } \\
\text { (Sulfolipids, } \\
\text { Glycosyldiacylglycerols) }\end{array}$ & HPTLC & [97] \\
\hline $\begin{array}{l}\text { Jania corniculata, } \\
\text { Laurencia papillosa }\end{array}$ & Suez Canal, Egypt & $\mathrm{EtOH}(70 \%), \mathrm{CH}_{2} \mathrm{Cl}_{2}$ & FA & GC-MS & [93] \\
\hline
\end{tabular}


Table 3. Cont

\begin{tabular}{|c|c|c|c|c|c|}
\hline Scientific Name & Collection Site & Extracting Solvent(s)/Method & $\begin{array}{l}\text { Isolated Lipids or Lipid } \\
\text { Classes }\end{array}$ & $\begin{array}{l}\text { Methods for Compounds } \\
\text { Identification }\end{array}$ & Ref. \\
\hline Laurencia okamurai & $\begin{array}{l}\text { Nanji Island in the East } \\
\text { China Sea, Zhejiang } \\
\text { Province, China }\end{array}$ & $\begin{array}{l}\text { EtOH }(95 \%) \text { extract partitioned } \\
\text { with } \mathrm{Et}_{2} \mathrm{O} \text { and fractionated by } \\
\mathrm{SiO}_{2}(\text { gradient system: petroleum } \\
\left.\text { ether }-\mathrm{CH}_{2} \mathrm{Cl}_{2}(10: 0 \rightarrow 1: 9)\right) \text {, } \\
\text { Sephadex column, and } \\
\text { purification by semi-preparative } \\
\text { C18 HPLC }\end{array}$ & $\begin{array}{c}\text { FA ethyl esters } \\
\text { [(9Z,12Z,15Z,18Z,21Z)- } \\
\text { ethyl tetracosa- } \\
\text { 9,12,15,18,21-Pentaenoate, } \\
(10 Z, 13 Z) \text {-ethyl } \\
\text { nonadeca-10,13-dienoate, } \\
\text { (9Z,12Z)-ethyl } \\
\text { nonadeca-9,12-dienoate, } \\
\text { ( } Z \text {-ethyl } \\
\text { octadec-13-enoate (4), and } \\
\text { ( } Z \text { )-ethyl } \\
\text { hexadec-11-enoate] }\end{array}$ & $\begin{array}{l}{ }^{1} \mathrm{H} \text { and }{ }^{13} \mathrm{C} \text { NMR, } 1 \mathrm{D} \text { and } \\
\text { 2D NMR, IR, HR-EI-MS }\end{array}$ & [109] \\
\hline Laurencia spp. & $\begin{array}{c}\text { Pulau Tioman, Pahang, } \\
\text { Pulau Karah, Terengganu, } \\
\text { Pulau Nyireh, } \\
\text { Terengganu, Malaysia }\end{array}$ & $\begin{array}{l}\mathrm{MeOH} \text {. Extract partitioned with } \\
\mathrm{Et}_{2} \mathrm{O} \text { and } \mathrm{H}_{2} \mathrm{O} \text { and fractionated } \\
\text { by } \mathrm{SiO}_{2} \text { column (hexane/EtOAc) }\end{array}$ & $\begin{array}{l}\text { Sesquiterpenes } \\
\text { (Halogenated } \\
\text { sesquiterpenes) }\end{array}$ & $\begin{array}{l}{ }^{1} \mathrm{H} \text { and }{ }^{13} \mathrm{C} \text { NMR, } \\
\text { LREIMS, HREIMS }\end{array}$ & [110] \\
\hline Osmundaria obtusiloba & $\begin{array}{l}\text { Buzios, Rio de Janeiro, } \\
\text { Brazil }\end{array}$ & $\begin{array}{c}\text { Acetone insoluble material } \\
\text { extracted with } \mathrm{CHCl}_{3} / \mathrm{MeOH}(2: 1 \\
\text { and } 1: 2, v / v) \text {. Extract partitioned } \\
\left(\mathrm{CHCl}_{3} / \mathrm{MeOH} / 0.75 \% \mathrm{KCl}(8: 4: 3,\right. \\
v / v)) . \text { Fractionation on } \mathrm{SiO}_{2} \\
\text { column }\left(\mathrm{CHCl}_{3} \text {, acetone and }\right. \\
\mathrm{MeOH}) . \mathrm{MeOH} \text { fraction purified } \text { on } \mathrm{SiO}_{2} \text { column }\left(\mathrm{CHCl} / \mathrm{MeOH}_{3}\right. \\
90: 10, v / v)\end{array}$ & $\begin{array}{c}\text { Glycolipids } \\
\text { (Sulfoglycolipids) }\end{array}$ & $\begin{array}{c}{ }^{1} \mathrm{H} \text { and }{ }^{13} \mathrm{C} \text { NMR, } \\
\text { ESI-MS/MS }\end{array}$ & [111] \\
\hline $\begin{array}{l}\text { Palmaria palmata, } \\
\text { Grateloupia turuturu }\end{array}$ & Batz-sur-Mer, France & $\begin{array}{c}\mathrm{CH}_{2} \mathrm{Cl}_{2} / \mathrm{MeOH}(2: 1, v / v) \\
\mathrm{MeOH} / \mathrm{H}_{2} \mathrm{O}(1: 1, v / v)\end{array}$ & Polar lipids & ${ }^{1} \mathrm{H}$ and ${ }^{13} \mathrm{C}$ NMR & [112] \\
\hline Pyropia orbicularis & Maitencillo, Chile & $\begin{array}{c}\mathrm{MeOH} \text {, acetone, } \mathrm{CH}_{2} \mathrm{Cl}_{2} \\
n \text {-hexane. Soxhlet extractor. } \\
n \text {-hexane extract fractionated on } \\
\mathrm{SiO}_{2} \text { column }(2,10,20,30 \text { and } \\
100 \% \text { acetone })\end{array}$ & $\begin{array}{c}\text { Phospholipids (main } \\
\text { compounds PC-O, PE, PS, } \\
\text { PI, SM, GlCer), } \\
\text { Glycolipids (MGDG), } \\
\text { Triacylglycerol, DAG }\end{array}$ & LC-ESI-MS/MS & [113] \\
\hline
\end{tabular}


Table 3. Cont

\begin{tabular}{|c|c|c|c|c|c|}
\hline Scientific Name & Collection Site & Extracting Solvent(s)/Method & $\begin{array}{l}\text { Isolated Lipids or Lipid } \\
\text { Classes }\end{array}$ & $\begin{array}{l}\text { Methods for Compounds } \\
\text { Identification }\end{array}$ & Ref. \\
\hline Sphaerococcus coronopifolius & Atlantic coast of Morocco & $\begin{array}{c}\mathrm{MeOH} / \mathrm{CH}_{2} \mathrm{Cl}_{2} \text {. Extract } \\
\text { separated on } \mathrm{SiO}_{2} \text { column } \\
\text { (hexane, gradients of } \\
\text { hexane/CH} \mathrm{Cl}_{2} \text { and } \\
\mathrm{CH}_{2} \mathrm{Cl}_{2} / \text { acetone, and } \mathrm{MeOH} \text { ) }\end{array}$ & $\begin{array}{l}\text { Bromoditerpenes } \\
\text { (Sphaerolabdadiene-3,14-diol } \\
\text { (1), Sphaerococcenol) }\end{array}$ & $\begin{array}{c}{ }^{1} \mathrm{H} \text { and }{ }^{13} \mathrm{C} \text { NMR, HRMS, } \\
\text { EIMS, CIMS, FTIR, UV }\end{array}$ & [114] \\
\hline \multicolumn{6}{|c|}{ Macroalgae-Ochrophyta } \\
\hline $\begin{array}{l}\text { Dictyota cervicornis, } \\
\text { Dictyota menstrualis }\end{array}$ & $\begin{array}{c}\text { Buzios, Rio de Janeiro, } \\
\text { Brazil }\end{array}$ & $\begin{array}{c}\text { Acetone insoluble material } \\
\text { extracted with } \mathrm{CHCl}_{3} / \mathrm{MeOH}(2: 1 \\
\text { and } 1: 2, v / v) \text {. Extract partitioned } \\
\text { on } \mathrm{SiO}_{2} \text { column }\left(\mathrm{CHCl} l_{3} \text {, acetone }\right. \\
\text { or } \mathrm{MeOH})\end{array}$ & $\begin{array}{l}\text { Glycolipid-rich extracts } \\
\text { (Sulfoglycolipids, } \\
\text { Glycosyldiacylglycerols) }\end{array}$ & HPTLC & [97] \\
\hline \multirow[b]{2}{*}{$\begin{array}{c}\text { Dictyota fasciola, Taonia } \\
\text { atomaria }\end{array}$} & Mediterranean Sea, Egypt & $\begin{array}{c}\mathrm{CHCl}_{3} / \mathrm{MeOH}(2: 1, v / v) . \\
\text { Glycolipid separation using } \\
\text { acetone on } \mathrm{SiO}_{2} \text { column }\end{array}$ & $\begin{array}{l}\text { Glycolipid-rich extracts } \\
\text { (DGDG) }\end{array}$ & GC-FID, LC-MS/MS & [103] \\
\hline & Mediterranean Sea, Egypt & $\begin{array}{c}\mathrm{MeOH} / \mathrm{CHCl}_{3}(2: 1, v / v) . \\
\text { Sulfolipid isolation: } \\
\text { diethylaminoethyl-cellulose } \\
\text { column }\left(\mathrm{CHCl}_{3} / \mathrm{MeOH}(6: 4, v / v)\right. \\
\left.\text { and } \mathrm{NH}_{3}\right)\end{array}$ & Glycolipids (Sulfolipids) & $\begin{array}{l}\text { GC-MS, GC-FID, } \\
\text { LC-MS/MS, IR }\end{array}$ & [89] \\
\hline Fucus evanescens & $\begin{array}{c}\text { West coast of Ungava Bay, } \\
\text { Canada }\end{array}$ & $\begin{array}{c}\text { EtOAc }(99 \%), \mathrm{CH}_{2} \mathrm{Cl}_{2 .} \text { EtOAc } \\
\text { algal extract acetylated and } \\
\text { organic layer purified by flash } \\
\text { chromatography }(0 \% \rightarrow 50 \% \\
\text { EtOAc in hexane and flushed } \\
\text { with } 100 \% \text { EtOAc and } 5 \% \mathrm{MeOH} \\
\text { in } 95 \% \text { EtOAc) }\end{array}$ & Glycolipid-rich extracts & ${ }^{1} \mathrm{H}$ and ${ }^{13} \mathrm{C}$ NMR & [115] \\
\hline Himanthalia elongata & Las Palmas, Spain & $\begin{array}{l}\text { Pressurized liquid extraction } \\
\text { Hexane, EtOH, } \mathrm{H}_{2} \mathrm{O}\end{array}$ & Sterol (Fucosterol), FA & GC-MS, HPLC-DAD & [116] \\
\hline Laminaria cichorioides & $\begin{array}{l}\text { Khasan region of the } \\
\text { Primorskii Territory, in the } \\
\text { Troitsa Gulf (the Sea of } \\
\text { Japan), Russia }\end{array}$ & $\begin{array}{l}\mathrm{EtOH}(96 \%) \text {. Lipophilic fraction } \\
\text { extracted with } \mathrm{CHCl}_{3} \text {. } \\
\text { Fractionation of lipid classes on } \\
\mathrm{SiO}_{2} \text { column }\end{array}$ & $\begin{array}{l}\text { Glycolipids (MGDG, } \\
\text { DGDG, SQDG), Free FA, } \\
\text { PUFA }\end{array}$ & & [91] \\
\hline
\end{tabular}


Table 3. Cont.

\begin{tabular}{|c|c|c|c|c|c|}
\hline Scientific Name & Collection Site & Extracting Solvent(s)/Method & $\begin{array}{l}\text { Isolated Lipids or Lipid } \\
\text { Classes }\end{array}$ & $\begin{array}{l}\text { Methods for Compounds } \\
\text { Identification }\end{array}$ & Ref. \\
\hline Sargassum dentifolium & Suez Canal, Egypt & $\mathrm{EtOH}(70 \%), \mathrm{CH}_{2} \mathrm{Cl}_{2}$ & FA & GC-MS & [93] \\
\hline $\begin{array}{l}\text { Sargassum fusiforme, } \\
\text { Sargassum vulgare }\end{array}$ & Red Sea, Egypt & $\mathrm{Et}_{2} \mathrm{O}, \mathrm{MeOH}, \mathrm{EtOH}, \mathrm{CHCl}_{3}$ & Terpenoids, FA & GC-MS & [117] \\
\hline Sargassum pallidum & $\begin{array}{l}\text { Trinity Bay in the Peter } \\
\text { the Great Gulf, Russia }\end{array}$ & $\begin{array}{c}\mathrm{EtOH} ; \mathrm{EtOH} / \mathrm{acetone}(1: 1, v / v) \\
\mathrm{EtOH} / \mathrm{CHCl}_{3}(1: 1, v / v) . \\
\text { Fractionation of lipid classes on } \\
\mathrm{SiO}_{2} \text { column (hexane, } \\
\mathrm{Et}_{2} \mathrm{O} / \text { hexane with increasing } \\
\text { ether concentration }(95: 5 \rightarrow 50: 50, \\
\left.v / v) \text { and } \mathrm{CHCl}_{3}\right)\end{array}$ & $\begin{array}{c}\text { Glycolipids (MGDG, } \\
\text { SQDG; DGDG), Free } \\
\text { FA/Esters, } \\
\text { Triacylglycerols, DAG }\end{array}$ & & [118] \\
\hline Sargassum vulgare & Sepetiba Bay, Brazil & $\begin{array}{c}\mathrm{CHCl}_{3} / \mathrm{MeOH}(2: 1 \text { and } 1: 2, v / v) \\
\text { Fractionated on } \mathrm{SiO}_{2} \text { column } \\
\left(\mathrm{CHCl}_{3} \text {, acetone and } \mathrm{MeOH}\right)\end{array}$ & $\begin{array}{l}\text { Glycolipid-rich extracts } \\
\text { (Sulfoglycolipids) }\end{array}$ & $\begin{array}{c}{ }^{1} \mathrm{H} \text { and }{ }^{13} \mathrm{C} \text { NMR, } \\
\text { ESI-MS-MS }\end{array}$ & [119] \\
\hline Sargassum wightii & Gulf of Mannar, India & $\begin{array}{l}\mathrm{MeOH} \text {. Isolation on } \mathrm{SiO}_{2} \text { column } \\
\text { (hexane/EtOAc, } \mathrm{EtOAc} / \mathrm{MeOH}) . \\
\text { Purification on flash } \mathrm{SiO}_{2} \text { column } \\
\quad\left(\mathrm{CHCl}_{3} / \mathrm{MeOH} \text { gradients }\right)\end{array}$ & $\begin{array}{c}\text { Glycolipid } \\
\text { (Sulfoglycerolipid, } \\
\text { 1-O-palmitoyl-3- } \\
O\left(6^{\prime} \text {-sulfo- } \alpha-\right. \\
\text { quinovopyranosyl)- } \\
\text { glycerol) }\end{array}$ & ${ }^{1} \mathrm{H}$ and ${ }^{13} \mathrm{C}$ NMR, IR & [120] \\
\hline \multicolumn{6}{|c|}{ Microalgae } \\
\hline Chaetoceros muelleri & & $\begin{array}{l}\text { Supercritical fluid extraction, } \\
\text { EtOH }(99.5 \%)\end{array}$ & $\begin{array}{c}\text { Triacylglycerol, DAG, } \\
\text { MAG, sterols (cholesterol), } \\
\text { FA }\end{array}$ & HPLC-ELSD, GC-FID & [121] \\
\hline Chlorococcum HS-101 & Japan & $\begin{array}{l}\mathrm{MeOH} \text { extract, partitioned with } \\
\text { hexane. } \mathrm{SiO}_{2} \text { column } \\
\text { (MeOH/CHCl}{ }_{3} \text { gradient). Active } \\
\text { fraction recovered with } \\
\mathrm{MeOH} / \mathrm{CHCl}_{3}(5: 95, v / v)\end{array}$ & FA & ${ }^{1} \mathrm{H}$ and ${ }^{13} \mathrm{C}$ NMR, GC-MS & [122] \\
\hline
\end{tabular}


Table 3. Cont.

\begin{tabular}{|c|c|c|c|c|c|}
\hline Scientific Name & Collection Site & Extracting Solvent(s)/Method & $\begin{array}{c}\text { Isolated Lipids or Lipid } \\
\text { Classes }\end{array}$ & $\begin{array}{l}\text { Methods for Compounds } \\
\text { Identification }\end{array}$ & Ref. \\
\hline Dunaliella salina & Jerusalem, Israel & $\begin{array}{l}\text { Pressurized liquid extracts: } \\
\text { hexane, petroleum ether, EtOH }\end{array}$ & $\begin{array}{c}\text { FA } \\
\text { Sesquiterpenoids } \\
\text { (Neophytadiene), } \\
\text { Diterpenoid (Phytol) }\end{array}$ & GC-MS & [123] \\
\hline Navicula delognei & $\begin{array}{l}\text { Lepreau Ledges, New } \\
\text { Brunswick, Canada }\end{array}$ & $\begin{array}{c}\mathrm{MeOH}, \mathrm{CHCl}_{3} \text {, extract } \\
\text { chromatographed on } \mathrm{SiO}_{2} \\
\text { column }\left(\mathrm{CHCl}_{3} \text { and }\right. \\
\mathrm{CHCl}_{3 / \mathrm{MeOH})}\end{array}$ & $\begin{array}{c}\text { FA }[(6 Z, 9 Z, 12 Z, 15 Z)- \\
\text { hexadecatetraenoic acid, } \\
(6 Z, 9 Z, 12 Z, 15 Z)- \\
\text { octadecatetraenoic acid), } \\
\text { Ester ((E)-phytol } \\
\text { (5Z,8Z,11Z,14Z,17Z)- } \\
\text { eicosapentaenoate] }\end{array}$ & ${ }^{1} \mathrm{H}$ and ${ }^{13} \mathrm{C}$ NMR, GC-MS & [124] \\
\hline \multirow[t]{2}{*}{ Phaeodactylum tricornutum } & $\begin{array}{l}\text { Experimental Phycology } \\
\text { and Culture Collection of } \\
\text { Algae at the University of } \\
\text { Göttingen (Germany) }\end{array}$ & $\begin{array}{c}\text { EtOAc and } \mathrm{MeOH} \text { extracts } \\
\text { applied to } \mathrm{SiO}_{2} \text { Sep Pak } \\
\text { cartridges. EtOAc extract eluted } \\
\text { with } 10 \% \text { step increases of } \\
\text { hexane/EtOAc until } 100 \% \text { EtOAc. } \\
\text { MeOH extract eluted with } 10 \% \\
\text { step increases of EtOAc/MeOH } \\
\text { until } 100 \% \mathrm{MeOH}\end{array}$ & $\begin{array}{c}\text { Free FA (palmitoleic acid, } \\
\text { HTA) }\end{array}$ & ${ }^{1} \mathrm{H}$ and ${ }^{13} \mathrm{C}$ NMR, ESI-MS & [125] \\
\hline & & $\begin{array}{c}\mathrm{MeOH} / \mathrm{H}_{2} \mathrm{O}(5: 1, v / v) \text {. Extract } \\
\text { redissolved in } \mathrm{MeOH}(70 \%) \text { and } \\
\text { fractioned on Sep Pak cartridge } \\
(\mathrm{MeOH}(70 \%) \text { followed by } \\
\text { constant volumes of MeOH (5\% } \\
\text { steps } \rightarrow 100 \%) \text { ). Fractionated by } \\
\text { RP HPLC }\end{array}$ & FA (EPA) & ${ }^{1} \mathrm{H}$ NMR, ESI-MS & [126] \\
\hline Synechocystis sp. & Las Palmas, Spain & $\begin{array}{l}\text { Pressurized liquid extraction: } \\
\text { hexane, } \mathrm{EtOH}, \mathrm{H}_{2} \mathrm{O}\end{array}$ & $\begin{array}{l}\text { FA, Sesquiterpenoids } \\
\text { (Neophytadiene) }\end{array}$ & GC-MS, HPLC-DAD & [116] \\
\hline
\end{tabular}


Table 4. Antimicrobial activity of algae lipids or algae lipid-rich extracts.

\begin{tabular}{|c|c|c|c|c|c|c|}
\hline Scientific Name & $\begin{array}{l}\text { Antimicrobial } \\
\text { Activity }\end{array}$ & Tested Microorganisms & $\begin{array}{l}\text { Antimicrobial Testing } \\
\text { Method/Evaluation }\end{array}$ & $\begin{array}{c}\text { Reference } \\
\text { Antimicrobial } \\
\text { (Positive Control) }\end{array}$ & $\begin{array}{c}\text { MIC, MBC, Diameter of } \\
\text { Inhibition Zone (IZ, in mm) } \\
\text { or Other }\end{array}$ & Ref. \\
\hline \multicolumn{7}{|c|}{ Macroalgae-Chlorophyta } \\
\hline Caulerpa racemosa & Antiviral & Viruses: Cox B3, HSV & $\begin{array}{l}\text { Cytopathic effect (CPE) } \\
\text { reduction assay, } \\
\text { 3-(4,5-dimethylthiazol-2- } \\
\text { yl)-2,5-diphenyltetrazolium } \\
\text { bromide (MTT) method }\end{array}$ & $\begin{array}{l}\text { Acyclovir (HSV), } \\
\text { Ribavirin (Cox B3) }\end{array}$ & $\begin{array}{c}\mathrm{IC}_{50} / \mathrm{CC}_{50}(\mu \mathrm{g} / \mathrm{mL}) / \mathrm{SI} \\
\text { Cox B3: } 31.3 / 500 / 16 \\
\text { HSV: } 7.9 / 250\end{array}$ & [95] \\
\hline $\begin{array}{c}\text { Caulerpa racemosa, } \\
\text { Ulva fasciata }\end{array}$ & Antiviral & $\begin{array}{c}\text { Viruses: HSV-1-ACVs, } \\
\text { HSV-1-ACVr }\end{array}$ & Titer reduction & & & [97] \\
\hline $\begin{array}{l}\text { Caulerpa spp., } \\
\text { Chlorodesmis fastigiata, } \\
\text { Halimeda spp., } \\
\text { Penicillus capitatus, } \\
\text { Penicillus dumentosus, } \\
\text { Penicillus pyriformis, } \\
\text { Rhipocephalus phoenix, } \\
\text { Udotea argentea, } \\
\text { Udotea cyathiformis, } \\
\text { Udotea flabellum, } \\
\text { Udotea petiolata }\end{array}$ & $\begin{array}{l}\text { Antibacterial, } \\
\text { Antifungal }\end{array}$ & $\begin{array}{c}\text { G(-): Serratia marinoruba, Vibrio } \\
\text { splendida, V. harveyi, V. leiognathi, } \\
\text { Vibrio sp. } \\
\text { Undescribed bacteria: VJP } \\
\text { Cal8101, VJP Cal8102, VJP } \\
\text { Cal8103 } \\
\text { Fungi: Leptosphaeria sp. } \\
\text { Lulworthia sp., Alternaria sp., } \\
\text { Dreschleria haloides, Lindra } \\
\text { thallasiae, } \\
\text { Undescribed fungi: VJP Cal8104, } \\
\text { VJP Cal8105 }\end{array}$ & Plate assay-disk method & & $\mathrm{IZ}(\mathrm{mm})>2$ & [98] \\
\hline Chaetomorpha linum & Antibacterial & $\begin{array}{c}\text { G(+): Pseudomonas sp., } \\
\text { Staphylococcus sp., Streptococcus } \\
\text { agalactiae, Enterococcus sp. } \\
\text { G(-): Vibrio alginolyticus, V. } \\
\text { harveyi, V. mediterranei, V. ordalii, } \\
\text { V. parahaemolyticus, V. salmonicida, } \\
\text { V. vulnificus } \\
\text { Yeast: C. albicans, } \\
\text { Candida famata, C. glabrata }\end{array}$ & Disk diffusion method & & $\begin{array}{c}\text { IZ (mm) } \\
\text { V. ordalii: 8-12 } \\
\text { V. vulnificus: 8-12 }\end{array}$ & [99] \\
\hline
\end{tabular}


Table 4. Cont.

\begin{tabular}{|c|c|c|c|c|c|c|}
\hline Scientific Name & $\begin{array}{l}\text { Antimicrobial } \\
\text { Activity }\end{array}$ & Tested Microorganisms & $\begin{array}{l}\text { Antimicrobial Testing } \\
\text { Method/Evaluation }\end{array}$ & $\begin{array}{c}\text { Reference } \\
\text { Antimicrobial } \\
\text { (Positive Control) }\end{array}$ & $\begin{array}{c}\text { MIC, MBC, Diameter of } \\
\text { Inhibition Zone (IZ, in mm) } \\
\text { or Other }\end{array}$ & Ref. \\
\hline $\begin{array}{c}\text { Codium } \\
\text { amplivesiculatum }\end{array}$ & Antibacterial & $\begin{array}{c}\mathrm{G}(+) \text { : S. aureus (ATCC BAA-42, } \\
\text { resistant to methicillin, penicillin, } \\
\text { ampicillin/sulbactam, oxacillin, } \\
\text { cefalotine) } \\
\text { G(-): V. parahaemolyticus (17802) }\end{array}$ & Disk diffusion method & & $\begin{array}{c}\text { MIC }(\mu \mathrm{g} / \mathrm{mL}) / \mathrm{IZ}(\mathrm{mm}) \\
\text { S. aureus: } 125 / 15 \\
\text { V. parahaemolyticus: }>250 / 8\end{array}$ & {$[100]$} \\
\hline \multirow{4}{*}{ Ulva fasciata } & Antiviral & $\begin{array}{l}\text { Virus: Semeliki Forest Virus } \\
\text { (SFV) }\end{array}$ & & & $\begin{array}{l}20 \mathrm{mg} / \mathrm{mouse} / 7 \text { days by } \\
\text { giving } 50 \% \text { protection }\end{array}$ & {$[101]$} \\
\hline & Antiviral & $\begin{array}{c}\text { Viruses: Japanese encephalitis } \\
\text { virus (JEV), } \\
\text { encephalomyocarditis (EMC) } \\
\text { virus }\end{array}$ & 96-well microtiter plates & & $\begin{array}{c}\mathrm{CC}_{50}(\mu \mathrm{g} / \mathrm{mL}) / \mathrm{EC}_{50} \\
(\mu \mathrm{g} / \mathrm{mL}) / \mathrm{TI} \\
\text { JEV: } 7.8 / 3.9 / 2.0\end{array}$ & {$[102]$} \\
\hline & Antifungal, Antiviral & $\begin{array}{l}\text { Yeast: C. albicans; } \\
\text { Fungus: } \text { A. niger } \\
\text { Virus: HSV-1 }\end{array}$ & $\begin{array}{l}\text { Disk diffusion method; } \\
\text { plaque reduction assay } \\
\text { (antiviral) }\end{array}$ & & $\begin{array}{c}\mathrm{MIC}(\mu \mathrm{g} / \mathrm{mL}) / \mathrm{IZ}(\mathrm{mm}) \\
\text { C. albicans: } 60 / 8 \\
\text { A. niger: } 80 / 13 \\
\text { HSV-1: } 9.37-15.62 \%\end{array}$ & [103] \\
\hline & $\begin{array}{c}\text { Antibacterial, } \\
\text { Antiviral }\end{array}$ & $\begin{array}{l}\mathrm{G}(+): \text { B. subtilis RRL B-94 } \\
\mathrm{G}(-) \text { : E. coli NRRL B-3703 } \\
\text { Virus: HSV-1 }\end{array}$ & Disk diffusion method & $\begin{array}{l}\text { Chloramphenicol } \\
\text { (bacteria), Acyclovir } \\
\text { (virus) }\end{array}$ & $\begin{array}{c}\text { MIC }(\mu \mathrm{g} / \mathrm{mL}) / \mathrm{IZ}(\mathrm{mm}) \\
\text { PI }(\%) \\
\text { E. coli: } 60 / 13 \\
\text { B. subtilis: } 40 / 16 \\
\text { HSV-1: } 18.75-46.87 \%\end{array}$ & [89] \\
\hline
\end{tabular}


Table 4. Cont.

\begin{tabular}{|c|c|c|c|c|c|c|}
\hline Scientific Name & $\begin{array}{l}\text { Antimicrobial } \\
\text { Activity }\end{array}$ & Tested Microorganisms & $\begin{array}{l}\text { Antimicrobial Testing } \\
\text { Method/Evaluation }\end{array}$ & $\begin{array}{c}\text { Reference } \\
\text { Antimicrobial } \\
\text { (Positive Control) }\end{array}$ & $\begin{array}{c}\text { MIC, MBC, Diameter of } \\
\text { Inhibition Zone (IZ, in mm) } \\
\text { or Other }\end{array}$ & Ref. \\
\hline Ulva rigida & Antibacterial & $\begin{array}{c}\text { G(+): S. agalactiae, S. aureus } \\
\text { (ATCC 25923), S. aureus (ATCC } \\
\text { 6538), E. faecalis (ATCC 29212), } \\
\text { Micrococcus sp. } \\
\text { G(-): Vibrio tapetis (CECT4600), } \\
\text { V. anguillarum (ATCC 12964T), } \\
\text { V. alginolyticus (ATCC 17749T), } \\
\text { E. coli O126-B16 (ATTC 14948), } \\
\text { E. coli (ATCC 25922), E. coli } \\
\text { (ATCC 8739), Pseudomonas } \\
\text { cepacia, P. fluorescens (AH2), } \\
\text { P. aeruginosa (ATCC 27853), } \\
\text { Aeromonas salmonicida } \\
\text { (LMG3780), A. hydrophila B3, } \\
\text { S. typhimurium (C52) } \\
\text { Yeast: C. albicans (ATCC10231) }\end{array}$ & $\begin{array}{l}\text { Disk diffusion method } \\
\text { and broth microdilution } \\
\text { technique }\end{array}$ & & $\begin{array}{l}\mathrm{IZ}(\mathrm{mm}) \\
6.3-16.3\end{array}$ & [27] \\
\hline \multicolumn{7}{|c|}{ Macroalgae-Rhodophyta } \\
\hline $\begin{array}{c}\text { Chondrus crispus, } \\
\text { Gracilaria } \\
\text { vermiculophylla, } \\
\text { Porphyra dioica }\end{array}$ & $\begin{array}{l}\text { Antibacterial, } \\
\text { Antifungal }\end{array}$ & $\begin{array}{c}\text { G(+): Listeria innocua (NCTC } \\
\text { 11286), B. cereus (ATCC 11778), } \\
\text { E. faecalis (LMG S 19456 5002), } \\
\text { Lactobacillus brevis (LMG 6906), } \\
\text { S. aureus (ATCC 6538), MRSA } \\
\text { G(-): E. coli (ATCC 8739), } \\
\text { Salmonella enteritidis (ATCC } \\
\text { 3076), P. aeruginosa (ATTC 10145) } \\
\text { Yeast: Candida spp. } \\
\text { (CCUG 49242) }\end{array}$ & Disk diffusion method & $\begin{array}{c}\text { Ampicillin }(L . \\
\text { innocua), } \\
\text { Cycloheximide } \\
\text { (Candida spp.), } \\
\text { Chloramphenicol } \\
\text { (other } \\
\text { microorganisms) }\end{array}$ & $\begin{array}{c}\mathrm{IZ}(\mathrm{mm}) \\
\text { C. crispus: } 5<\mathrm{IZ} \leq 20 \\
\text { G. vermiculophylla: } 10<\mathrm{IZ} \leq \\
15 \\
\text { P. dioica: } 5<\mathrm{IZ} \leq 12\end{array}$ & {$[105]$} \\
\hline
\end{tabular}


Table 4. Cont.

\begin{tabular}{|c|c|c|c|c|c|c|}
\hline Scientific Name & $\begin{array}{l}\text { Antimicrobial } \\
\text { Activity }\end{array}$ & Tested Microorganisms & $\begin{array}{l}\text { Antimicrobial Testing } \\
\text { Method/Evaluation }\end{array}$ & $\begin{array}{c}\text { Reference } \\
\text { Antimicrobial } \\
\text { (Positive Control) }\end{array}$ & $\begin{array}{c}\text { MIC, MBC, Diameter of } \\
\text { Inhibition Zone (IZ, in mm) } \\
\text { or Other }\end{array}$ & Ref. \\
\hline $\begin{array}{l}\text { Falkenbergia } \\
\text { (heteromorphic } \\
\text { sporophyte of } \\
\text { Asparagopsis } \\
\text { taxiformis) }\end{array}$ & Antibacterial & $\begin{array}{c}\mathrm{G}(+) \text { : S. epidermidis, S. aureus, } B . \\
\text { subtilis } \\
\text { G(-): V. vulnificus (MTCC 1145), } \\
\text { V. parahaemolyticus (MTCC 451), } \\
\text { V. harveyi (MTCC 3438), V. } \\
\text { alginolyticus (MTCC 4439), V. } \\
\text { alcaligenes (MTCC 4442), } P . \\
\text { aeruginosa, K. pneumoniae }\end{array}$ & Broth dilution method & $\begin{array}{l}\text { Chloramphenicol, } \\
\text { Nalidixic acid }\end{array}$ & $\begin{array}{c}\text { IZ }(\mathrm{mm}) / \mathrm{MIC}(\mu \mathrm{g}) / \mathrm{MBC}(\mu \mathrm{g}) \\
\text { S. epidermidis: } 21 / 1250 / 270 \\
\text { S. aureus: } 21 / 750 / 170 \\
\text { B. subtilis: } 23 / 750 / 180 \\
\text { V. vulnificus: } 31 / 750 / 90 \\
\text { V. parahaemolyticus: } \\
\text { 28/750/110 } \\
\text { V. harveyi: } 26 / 750 / 60 \\
\text { V. alginolyticus: } 32 / 500 / 80 \\
\text { V. alcaligenes: } 33 / 500 / 50 \\
\text { P. aeruginosa: } 19 / 1250 / 420 \\
\text { K. pneumoniae: } 15 / 1250 / 380\end{array}$ & [106] \\
\hline \multirow[b]{2}{*}{$\begin{array}{l}\text { Galaxaura cylindrica, } \\
\text { Laurencia papillosa }\end{array}$} & Antiviral & Virus: HSV-1 & Plaque reduction assay & Acyclovir & $\begin{array}{c}\text { Inhibition (\%) } \\
\text { L. papillosa: } 9.37-31.25 \\
\text { G. cylindrica: } 15.62-28.12\end{array}$ & [103] \\
\hline & $\begin{array}{l}\text { Antibacterial, } \\
\text { Antiviral }\end{array}$ & $\begin{array}{c}\mathrm{G}(+) \text { : } \text { B. subtilis NRRL B-94 } \\
\mathrm{G}(-) \text { : E. coli NRRL B-3703 } \\
\text { Virus: (HSV-1) }\end{array}$ & Disk diffusion method & $\begin{array}{l}\text { Chloramphenicol } \\
\text { (bacteria), Acyclovir } \\
\text { (virus) }\end{array}$ & $\begin{array}{c}\text { MIC ( } \mu \mathrm{g} / \mathrm{mL}) / \mathrm{IZ}(\mathrm{mm}) \\
\text { PI }(\%) \\
\text { L. papillosa } \\
\text { E. coli: }-/ 8 \\
\text { B. subtilis: }-/ 11 \\
\text { HSV-1: } 40.62-59.37 \% \\
\text { G. cylindrica } \\
\text { E. coli: } 80 / 11 \\
\text { B. subtilis: } 80 / 11 \\
\text { HSV-1: } 45.87-59.37 \%\end{array}$ & [89] \\
\hline Gigartina tenella & Antiviral & HIV-reverse transcriptase type 1 & & & $\mathrm{IC}_{50} 11.2 \mu \mathrm{M}$ & [107] \\
\hline Gracilaria gracilis & Antibacterial & $\begin{array}{c}\mathrm{G}(+): \text { B. subtilis } \\
\mathrm{G}(-): V . \text { fischeri, V. cholerae, } P . \\
\text { aeruginosa, Salmonella sp., A. } \\
\text { hydrophila }\end{array}$ & Disk diffusion method & Chloramphenicol & $\begin{array}{c}\text { MIC: } 5 \mu \mathrm{g} / \text { disk } \\
\text { IZ }(\mathrm{mm}) \\
\text { B. subtilis } 10.3-17.6 \\
\left(\mathrm{CHCl}_{3}\right) / 10-15.6\left(\mathrm{Et}_{2} \mathrm{O}\right)\end{array}$ & [94] \\
\hline
\end{tabular}


Table 4. Cont

\begin{tabular}{|c|c|c|c|c|c|c|}
\hline Scientific Name & $\begin{array}{l}\text { Antimicrobial } \\
\text { Activity }\end{array}$ & Tested Microorganisms & $\begin{array}{l}\text { Antimicrobial Testing } \\
\text { Method/Evaluation }\end{array}$ & $\begin{array}{c}\text { Reference } \\
\text { Antimicrobial } \\
\text { (Positive Control) }\end{array}$ & $\begin{array}{c}\text { MIC, MBC, Diameter of } \\
\text { Inhibition Zone (IZ, in mm) } \\
\text { or Other }\end{array}$ & Ref. \\
\hline $\begin{array}{l}\text { Gracilariopsis } \\
\text { longissima }\end{array}$ & $\begin{array}{l}\text { Antibacterial, } \\
\text { Antifungal }\end{array}$ & $\begin{array}{c}\mathrm{G}(+) \text { : S. agalactiae, Enterococcus } \\
\text { sp. } \\
\text { G(-): P. aeruginosa, V. salmonicida, } \\
\text { V. fluvialis, V. vulnificus, V. cholerae } \\
\text { non-O1, V. alginolyticus } \\
\text { Yeast: C. albicans, C. famata, } \\
\text { C. glabrata }\end{array}$ & Disk diffusion method & & $\begin{array}{c}\text { IZ (mm) } \\
\text { V. alginolyticus: } 25 \\
\text { V. fluvialis: } 8 \\
\text { V. vulnificus: } 15 \\
\text { V. cholerae non-O-1:10 }\end{array}$ & [108] \\
\hline $\begin{array}{l}\text { Hypnea musciformis, } \\
\text { Osmundaria obtusiloba, } \\
\text { Porphyra acanthophora, } \\
\text { Pterocladiella capillacea }\end{array}$ & Antiviral & $\begin{array}{c}\text { Virus: HSV-1-ACVs, } \\
\text { HSV-1-ACVr }\end{array}$ & Titer reduction & & $\begin{array}{c}\text { PI(\%)/VII } \\
\text { O. obtusiloba } \\
\text { ACVs-HSV-1: } \\
\text { 82.2-99.5/0.75-2.35 } \\
\text { HSV-1-ACVr: } \\
\text { 99.7-99.9/2.5-4.5 }\end{array}$ & [97] \\
\hline $\begin{array}{l}\text { Jania corniculata, } \\
\text { Laurencia papillosa }\end{array}$ & $\begin{array}{l}\text { Antibacterial, } \\
\text { Antifungal }\end{array}$ & $\begin{array}{c}\mathrm{G}(+) \text { : B. subtilis, Staphylococcus } \\
\text { albus, E. faecalis } \\
\text { G(-): E. coli } \\
\text { Yeast: C. albicans } \\
\text { Fungus: A. flavus }\end{array}$ & Disk diffusion method & & $\begin{array}{c}11<\mathrm{IZ} \leq 15 \\
\text { No IZ (A.flavus) }\end{array}$ & [93] \\
\hline Laurencia okamurai & Antifungal & $\begin{array}{c}\text { Yeast: C. } \\
\text { neoformans (32609), C. glabrata } \\
\text { (537) } \\
\text { Fungi: Trichophyton rubrum } \\
\text { (Cmccftla), A. fumigatus (07544) }\end{array}$ & Broth dilution method & $\begin{array}{c}\text { Amphotericin B, } \\
\text { fluconazole, } \\
\text { voriconazole, } \\
\text { ketoconazole }\end{array}$ & $\begin{array}{l}\mathrm{MIC}_{80}(\mu \mathrm{g} / \mathrm{mL}) \\
\text { C. neoformans: } 8-64 \\
\text { C. glabrata: } 4-64 \\
\text { A. fumigatus: }>64 \\
\text { T. rubrum: } 64\end{array}$ & [109] \\
\hline Laurencia spp. & Antibacterial & $\begin{array}{c}\text { G(-): Chromobacterium violaceum, } \\
\text { P. mirabilis, } \\
\text { P. vulgaris, Erwinia sp., } \\
\text { V. parahaemolyticus, } V . \\
\text { alginolyticus }\end{array}$ & Disk diffusion method & & $\begin{array}{l}\text { MIC }(\mu \mathrm{g} / \mathrm{disk}) \\
\text { C. violaceum: } 10-40 \\
\text { P. mirabilis: } 20-40 \\
\text { P. vulgaris: } 20-40 \\
\text { Erwinia sp.: } 10-30 \\
\text { V. parahaemolyticus: } 20-40 \\
\text { V. alginolyticus: } 20-30\end{array}$ & [110] \\
\hline Osmundaria obtusiloba & Antiviral & Virus: HSV-1, HSV-2 & Titer reduction & Acyclovir & $\begin{array}{c}\mathrm{EC}_{50}(\mu \mathrm{g} / \mathrm{mL}) / \mathrm{SI} / \mathrm{PI}(\%) \\
\text { HSV-1: } 42 / 1.7 / 75 \\
\text { HSV-2: } 12 / 6 / 96\end{array}$ & [111] \\
\hline
\end{tabular}


Table 4. Cont

\begin{tabular}{|c|c|c|c|c|c|c|}
\hline Scientific Name & $\begin{array}{l}\text { Antimicrobial } \\
\text { Activity }\end{array}$ & Tested Microorganisms & $\begin{array}{l}\text { Antimicrobial Testing } \\
\text { Method/Evaluation }\end{array}$ & $\begin{array}{c}\text { Reference } \\
\text { Antimicrobial } \\
\text { (Positive Control) }\end{array}$ & $\begin{array}{c}\text { MIC, MBC, Diameter of } \\
\text { Inhibition Zone (IZ, in mm) } \\
\text { or Other }\end{array}$ & Ref. \\
\hline $\begin{array}{l}\text { Palmaria palmata, } \\
\text { Grateloupia turuturu }\end{array}$ & Antibacterial & G(-): V. harveyi ORM4 & $\begin{array}{l}\text { Broth microdilution } \\
\text { method }\end{array}$ & & $0.2<\mathrm{PI} \leq 7.9 \%$ & {$[112]$} \\
\hline Pyropia orbicularis & Antibacterial & $\begin{array}{c}G(+): \text { S. aureus, B. cereus } \\
\text { G(-): E. coli }\end{array}$ & Disk diffusion method & Kanamycin & $16<\mathrm{IZ}<26$ & [113] \\
\hline $\begin{array}{l}\text { Sphaerococcus } \\
\text { coronopifolius }\end{array}$ & $\begin{array}{c}\text { Antibacterial, } \\
\text { Antiplasmodial }\end{array}$ & $\begin{array}{c}\text { G(+): S. aureus (ATCC \# 6538) } \\
\text { Parasitic protozoa: P. falsciparum } \\
\text { (FCB1) }\end{array}$ & $\begin{array}{c}\text { Antibacterial: } \\
\text { Disk-diffusion, } \\
\text { Antimalarial: inhibition } \\
\text { of }\left[{ }^{3} \mathrm{H}\right] \text {-hypoxanthine } \\
\text { uptake by P. falsciparum } \\
\text { cultured in human blood }\end{array}$ & & $\begin{array}{l}\text { S. aureus-MIC: } 0.104-0-146 \\
\mu \mathrm{M} \\
\text { P. falciparum-IC } \\
50: 1 \mu \mathrm{M}\end{array}$ & {$[114]$} \\
\hline \multicolumn{7}{|c|}{ Macroalgae-Ochrophyta } \\
\hline $\begin{array}{l}\text { Dictyota cervicornis, } \\
\text { Dictyota menstrualis }\end{array}$ & Antiviral & $\begin{array}{c}\text { Virus: HSV-1-ACVs, } \\
\text { HSV-1-ACVr }\end{array}$ & Titer reduction & & & [97] \\
\hline \multirow{2}{*}{$\begin{array}{c}\text { Dictyota fasciola, Taonia } \\
\text { atomaria }\end{array}$} & $\begin{array}{c}\text { Antibacterial, } \\
\text { Antifungal, Antiviral }\end{array}$ & $\begin{array}{l}\text { G(+): B. subtilis } \\
\text { G(-): E. coli } \\
\text { Fungi: C. albicans, A. niger } \\
\text { Virus: HSV-1 }\end{array}$ & $\begin{array}{l}\text { Disk diffusion method } \\
\text { (antibacterial); Plaque } \\
\text { reduction assay } \\
\text { (antiviral) }\end{array}$ & & $\begin{array}{c}\text { D. fasciola: } \\
\text { Inhibition (\%) } \\
\text { HSV-1: } 50.00-81.25 \% \\
\text { T. atomaria: MIC } \\
\text { ( } \mu \mathrm{m} / \mathrm{mL}) / \mathrm{IZ}(\mathrm{mm}) \\
\text { B. subtilis: } 80 / 9, \text { E. coli: } 80 / 7, \text { C. } \\
\text { albicans: } 80 / 10, \\
\text { A. niger: } 60 / 12 \\
\text { Inhibition }(\%) \\
\text { HSV-1: } 31.25-34.37 \%\end{array}$ & [103] \\
\hline & $\begin{array}{c}\text { Antibacterial, } \\
\text { Antiviral }\end{array}$ & $\begin{array}{c}\mathrm{G}(+): \text {. subtilis NRRL B-94 } \\
\mathrm{G}(-) \text { : E. coli NRRL B-3703 } \\
\text { Virus: HSV-1 }\end{array}$ & $\begin{array}{l}\text { Disk diffusion method } \\
\text { (antibacterial); Plaque } \\
\text { reduction assay } \\
\text { (antiviral) }\end{array}$ & $\begin{array}{l}\text { Chloramphenicol } \\
\text { (bacteria), Acyclovir } \\
\text { (virus) }\end{array}$ & $\begin{array}{c}\text { MIC }(\mu \mathrm{g} / \mathrm{mL}) / \mathrm{IZ}(\mathrm{mm}) \\
\text { PI }(\%) \\
\text { D. fasciola } \\
\text { E. coli: }-/ 8 \\
\text { B. subtilis: }-/ 10 \\
\text { HSV-1: } 46.87-70.12 \% \\
\text { T. atomaria: } \\
\text { E. coli: } 60 / 15 \\
\text { B. subtilis: } 40 / 13 \\
\text { HSV-1: } 43.75-56.25 \%\end{array}$ & [89] \\
\hline
\end{tabular}


Table 4. Cont

\begin{tabular}{|c|c|c|c|c|c|c|}
\hline Scientific Name & $\begin{array}{l}\text { Antimicrobial } \\
\text { Activity }\end{array}$ & Tested Microorganisms & $\begin{array}{l}\text { Antimicrobial Testing } \\
\text { Method/Evaluation }\end{array}$ & $\begin{array}{c}\text { Reference } \\
\text { Antimicrobial } \\
\text { (Positive Control) }\end{array}$ & $\begin{array}{c}\text { MIC, MBC, Diameter of } \\
\text { Inhibition Zone (IZ, in mm) } \\
\text { or Other }\end{array}$ & Ref. \\
\hline Fucus evanescens & Antibacterial & $\begin{array}{c}\text { G(+): B. cereus, Clostridium } \\
\text { difficile, MRSA, Propionibacterium } \\
\text { acnes (ATCC and clinical isolate), } \\
\text { S. pyogenes } \\
\text { G(-): Acinetobacter baumannii, E. } \\
\text { coli, Haemophilus influenzae, K. } \\
\text { pneumoniae, Legionella } \\
\text { pneumophila, P. aeruginosa }\end{array}$ & Disk diffusion method & & $\mathrm{MIC}_{100}: 50 \mu \mathrm{g} / \mathrm{mL}$ & {$[115]$} \\
\hline Himanthalia elongata & Antibacterial & $\begin{array}{l}\text { G(+): S. aureus ATCC } 25923 \\
\text { G(-): E. coli ATCC } 11775 \\
\text { Yeast: C. albicans ATCC } 60193 \\
\text { Fungi: A. niger ATCC } 16404\end{array}$ & $\begin{array}{l}\text { Broth microdilution } \\
\text { method }\end{array}$ & & $\begin{array}{l}\text { MBC }(\mathrm{mg} / \mathrm{mL}) \\
\text { S. aureus: } 6.25 \\
\text { E. coli: } 6.00 \\
\text { MFC }(\mathrm{mg} / \mathrm{mL}) \\
\text { C. albicans: } 8 \\
\text { A. niger: } 12\end{array}$ & {$[116]$} \\
\hline Laminaria cichorioides & $\begin{array}{l}\text { Antibacterial, } \\
\text { Antifungal }\end{array}$ & $\begin{array}{c}\text { G(+): S. aureus ATCC } 21027 \\
\text { G(-): E. coli ATCC } 15034 \\
\text { Yeast: Safale S04, C. albicans } \\
\text { KMM } 455 \\
\text { Fungi: A. niger KMM } 4634, F \text {. } \\
\text { oxysporum KMM } 4639\end{array}$ & Disk diffusion method & $\begin{array}{l}\text { Fucoxanthin, } \\
\text { Nitrofungin }\end{array}$ & $\begin{array}{l}\text { IZ }(\mathrm{mm}) \\
\text { S. aureus: } 2-5 \\
\text { E. coli: } 1-6 \\
\text { C. albicans: } 1-6 \\
\text { A. niger: } 1-3 \\
\text { F. oxysporum: } 1-4\end{array}$ & [91] \\
\hline Sargassum dentifolium & $\begin{array}{l}\text { Antibacterial, } \\
\text { Antifungal }\end{array}$ & $\begin{array}{c}\mathrm{G}(+) \text { : B. subtilis, S. albus, E. } \\
\text { faecalis } \\
\mathrm{G}(-) \text { : } \text {. coli } \\
\text { Yeast: C. albicans } \\
\text { Fungus: A. flavus }\end{array}$ & Disk diffusion method & & $\begin{array}{c}11<\mathrm{IZ}(\mathrm{mm}) \leq 12 \\
\text { No IZ }(\text { A. flavus })\end{array}$ & [93] \\
\hline $\begin{array}{l}\text { Sargassum fusiforme, } \\
\text { Sargassum vulgare }\end{array}$ & Antibacterial & $\begin{array}{l}\text { Multidrug resistant: } \\
\text { S. aureus, } \\
\text { P. aeruginosa, } \\
\text { Shigella flexneri, } \\
\text { E. coli, } \\
\text { Corynebacterium sp. }\end{array}$ & Agar well diffusion & & $\begin{array}{c}9.33<\mathrm{IZ}(\mathrm{mm}) \leq 23.33 \\
\text { MIC: } 50-100 \mathrm{mg} / \mathrm{mL}\end{array}$ & {$[117]$} \\
\hline
\end{tabular}


Table 4. Cont.

\begin{tabular}{|c|c|c|c|c|c|c|}
\hline Scientific Name & $\begin{array}{l}\text { Antimicrobial } \\
\text { Activity }\end{array}$ & Tested Microorganisms & $\begin{array}{l}\text { Antimicrobial Testing } \\
\text { Method/Evaluation }\end{array}$ & $\begin{array}{c}\text { Reference } \\
\text { Antimicrobial } \\
\text { (Positive Control) }\end{array}$ & $\begin{array}{c}\text { MIC, MBC, Diameter of } \\
\text { Inhibition Zone (IZ, in mm) } \\
\text { or Other }\end{array}$ & Ref. \\
\hline Sargassum pallidum & $\begin{array}{l}\text { Antibacterial, } \\
\text { Antifungal }\end{array}$ & $\begin{array}{c}\mathrm{G}(+) \text { : S. aureus ATCC } 21027 \\
\text { G(-): E. coli ATCC } 15034 \\
\text { Yeast: C. albicans KMM } 455 \\
\text { Fungi: A. niger KMM 4634, F. } \\
\text { oxysporum KMM } 4639, \text { Septoria } \\
\text { glycines }\end{array}$ & Agar well diffusion & & $\begin{array}{c}\mathrm{IZ}(\mathrm{mm}) \\
\text { S. aureus: } 0.7-14.5 \\
\text { E. coli: } 0.5-6.7 \\
\text { C. albicans: } 1.0-4.5 \\
\text { A. niger: } 2.0-5.7 \\
\text { F. oxysporum: } 1.0-5.2 \\
\text { S. glycines: } 2.0-5.7\end{array}$ & [118] \\
\hline Sargassum vulgare & Antiviral & Virus: HSV-1, HSV-2 & Titer reduction & Acyclovir & $\begin{array}{c}\text { PI (\%) } \\
\text { HSV-1: } 96.0-99.9 \\
\text { HSV-2: } 99.9 \\
\end{array}$ & [119] \\
\hline Sargassum wightii & Antibacterial & $\begin{array}{c}\text { Xanthomonas oryzae pv. oryzae } \\
\text { CAS ar01 }\end{array}$ & Disk diffusion method & & $\mathrm{IZ}(\mathrm{mm}): 3.0-13.5$ & [120] \\
\hline \multicolumn{7}{|c|}{ Microalgae } \\
\hline Chaetoceros muelleri & $\begin{array}{l}\text { Antibacterial, } \\
\text { Antifungal }\end{array}$ & $\begin{array}{c}\mathrm{G}(+) \text { : Staphyloccocus aureus } \\
\text { (ATCC 25923) } \\
\text { G(-):E. coli (ATCC 11775) } \\
\text { Yeast: C. albicans (ATCC 60193) }\end{array}$ & $\begin{array}{l}\text { Broth microdilution } \\
\text { method }\end{array}$ & $\begin{array}{l}\text { Chloramphenicol, } \\
\text { Amphotericin B }\end{array}$ & $\begin{array}{l}\mathrm{MBC}(\mathrm{mg} / \mathrm{mL}) \\
\text { E. coli: } 12-15 \\
\text { S. aureus: } 12-17 \\
\text { C. albicans: } 7-9\end{array}$ & [121] \\
\hline Chlorococcum HS-101 & Antibacterial & $\begin{array}{c}\text { G(+): MRSA, S. aureus ATCC } \\
25923\end{array}$ & Disk diffusion method & $\begin{array}{l}\text { Gentamicin, } \\
\text { Amikacin, } \\
\text { Cephalosporin, } \\
\text { Habekacin, } \\
\text { Ampicillin, } \\
\text { Vancomycin, } \\
\text { Oxytetracyclin, } \\
\text { Erythromycin, } \\
\text { Cefmetazole, } \\
\text { Fosfomycin, } \\
\text { Imipenem, } \\
\text { Minomycin }\end{array}$ & IZ (mm): 18.7-28.3 & [122] \\
\hline
\end{tabular}


Table 4. Cont.

\begin{tabular}{|c|c|c|c|c|c|c|}
\hline Scientific Name & $\begin{array}{l}\text { Antimicrobial } \\
\text { Activity }\end{array}$ & Tested Microorganisms & $\begin{array}{l}\text { Antimicrobial Testing } \\
\text { Method/Evaluation }\end{array}$ & $\begin{array}{c}\text { Reference } \\
\text { Antimicrobial } \\
\text { (Positive Control) }\end{array}$ & $\begin{array}{c}\text { MIC, MBC, Diameter of } \\
\text { Inhibition Zone (IZ, in mm) } \\
\text { or Other }\end{array}$ & Ref. \\
\hline Dunaliella salina & $\begin{array}{l}\text { Antibacterial, } \\
\text { Antifungal }\end{array}$ & $\begin{array}{l}\mathrm{G}(+) \text { : S. aureus ATCC } 25923 \\
\text { G(-): E. coli ATCC } 11775 \\
\text { Yeast: C. albicans ATCC } 60193 \\
\text { Fungi: A. niger ATCC } 16404\end{array}$ & Disk diffusion method & $\begin{array}{l}\text { Chloramphenicol } \\
\text { (bacteria), } \\
\text { Amphotericin B } \\
\text { (yeast and fungi) }\end{array}$ & $\begin{array}{c}\mathrm{MBC}(\mathrm{mg} / \mathrm{mL}) \\
\text { E. coli: } 6-30 \\
\text { S. aureus: } 8-30 \\
\text { MFC }(\mathrm{mg} / \mathrm{mL}) \\
\text { C. albicans: } 12-30 \\
\text { A. niger: } 32->35\end{array}$ & [123] \\
\hline $\begin{array}{l}\text { Navicula delognei } \mathrm{f} . \\
\text { elliptica }\end{array}$ & Antibacterial & $\begin{array}{l}\text { G(+): Staphyloccus aureus (ATCC } \\
\text { 25923), S. epidermidis (ATCC } \\
\text { 12228) } \\
\text { G(-): S. typhimurium (ATCC } \\
\text { 14028), P. vulgaris (ATCC 13315), } \\
\text { Enterobacter cloacae (ATCC 23355), } \\
\text { E. coli (ATCC 25922), K. } \\
\text { pneumoniae (ATCC 13883), } \\
\text { Serratia marcescens (ATCC 8100) }\end{array}$ & Disk diffusion method & $\begin{array}{c}\text { Ampicillin, } \\
\text { Tetracycline, } \\
\text { Chloramphenicol }\end{array}$ & $\begin{array}{c}\mathrm{IZ}(\mathrm{mm}) \\
\text { S. aureus }>4 \\
\text { S. typhimurium }>4 \\
\text { S. epidermidis }>2 \\
\text { P. vulgaris }>2 \\
\text { E. coli IZ noticeable } \\
\text { No IZ (E. cloacae, K. } \\
\text { pneumoniae, S. marcescens) }\end{array}$ & {$[124]$} \\
\hline
\end{tabular}


Table 4. Cont.

\begin{tabular}{|c|c|c|c|c|c|c|}
\hline Scientific Name & $\begin{array}{l}\text { Antimicrobial } \\
\text { Activity }\end{array}$ & Tested Microorganisms & $\begin{array}{l}\text { Antimicrobial Testing } \\
\text { Method/Evaluation }\end{array}$ & $\begin{array}{c}\text { Reference } \\
\text { Antimicrobial } \\
\text { (Positive Control) }\end{array}$ & $\begin{array}{c}\text { MIC, MBC, Diameter of } \\
\text { Inhibition Zone (IZ, in mm) } \\
\text { or Other }\end{array}$ & Ref. \\
\hline \multirow[t]{2}{*}{$\begin{array}{l}\text { Phaeodactylum } \\
\text { tricornutum }\end{array}$} & $\begin{array}{l}\text { Antibacterial, } \\
\text { Antifungal }\end{array}$ & $\begin{array}{c}\text { G(+): } \\
\text { S. aureus } \\
\text { (SH1000), Bacillus weihenstephanensis } \\
\text { (10390), MRSA 252, MRSA 16a, } \\
\text { S. epidermidis, M. luteus (NCIMB } \\
\text { 9278), Planococcus citreus } \\
\text { (NCIMB 1493), B. cereus (883-00) } \\
\text { G(-): Alteromonas } \\
\text { haloplanktis (NCIMB 19), } \\
\text { A. hydrophila } \\
\text { (NCIMB 1108), } \\
\text { Photobacterium phosphoreum (NCIMB } \\
\text { 64), Psychrobacter immobilis (NCIMB } \\
\text { 308), Listonella anguillarum } \\
\text { (MT1637), E. coli B, } \\
\text { P. aeruginosa (NCIMB 10775) } \\
\text { Yeast: C. glabrata, Candida neoformis, } \\
\text { Candida sp., Saccharomyces cerevisiae } \\
\text { BY4741a }\end{array}$ & Disk diffusion method & Ampicillin & $\begin{array}{l}\mathrm{IC}_{50}(\mu \mathrm{M}) / \mathrm{MBC}(\mu \mathrm{M}) \\
\text { S. aureus: } 10-40 / 40-80\end{array}$ & [125] \\
\hline & $\begin{array}{l}\text { Antibacterial, } \\
\text { Antifungal }\end{array}$ & $\begin{array}{c}\text { G(+):M. luteus (NCIMB 9278), } \\
\text { Planococcus citreus (NCIMB 1493), } \\
\text { B. cereus (883-00), S. aureus (SH1000), } \\
\text { B. weihenstephanensis (10390), MRSA } \\
\text { 252, MRSA16a, S. epidermidis } \\
\text { G(-): Alteromonas haloplanktis } \\
\text { (NCIMB 19), A. hydrophila (NCIMB } \\
\text { 1108), Photobacterium phosphoreum } \\
\text { (NCIMB 64), Psychrobacter immobilis } \\
\text { (NCIMB308), Listonella anguillarum } \\
\text { (MT1637), E. coli B, P. aeruginosa } \\
\text { (NCIMB 10775) } \\
\text { Yeast:C. glabrata, C. neoformis, } \\
\text { Candida sp., S. cerevisiae BY4741a }\end{array}$ & Agar well diffusion & & $\begin{array}{c}\text { Growth inhibition }\left(\mathrm{mm}^{2}\right) \\
\leq 50->50 \\
\text { S. aureus: } 25-190 \mathrm{~mm}^{2}\end{array}$ & [126] \\
\hline
\end{tabular}


Table 4. Cont.

\begin{tabular}{|c|c|c|c|c|c|c|}
\hline Scientific Name & $\begin{array}{l}\text { Antimicrobial } \\
\text { Activity }\end{array}$ & Tested Microorganisms & $\begin{array}{l}\text { Antimicrobial Testing } \\
\text { Method/Evaluation }\end{array}$ & $\begin{array}{c}\text { Reference } \\
\text { Antimicrobial } \\
\text { (Positive Control) }\end{array}$ & $\begin{array}{c}\text { MIC, MBC, Diameter of } \\
\text { Inhibition Zone (IZ, in mm) } \\
\text { or Other }\end{array}$ & Ref. \\
\hline Synechocystis sp. & Antibacterial & $\begin{array}{l}\mathrm{G}(+) \text { : S. aureus ATCC } 25923 \\
\text { G(+): E. coli ATCC } 11775, \\
\text { Yeast: C. albicans ATCC } 60193 \\
\text { Fungi: A. niger ATCC } 16404\end{array}$ & $\begin{array}{l}\text { Broth microdilution } \\
\text { method }\end{array}$ & & $\begin{array}{c}\mathrm{MBC}(\mathrm{mg} / \mathrm{mL}) \\
\text { S. aureus: } 7 \\
\text { E. coli: } 5.6 \\
\text { MFC }(\mathrm{mg} / \mathrm{mL}) \\
\text { C. albicans: } 12 \\
\text { A. niger: } 14\end{array}$ & [116] \\
\hline
\end{tabular}

Abbreviations: CC: cytotoxic concentration; EC: effective concentration; HSV: herpes simplex virus; IC: inhibitory concentration; IZ: inhibition zone; MIC: minimum inhibitory concentration; MBC: minimum bactericidal concentration; MFC: minimum fungicidal concentration; MRSA: methycillin-resistant Staphylococcus aureus; PI: percentage of inhibition; SI: selectivity index; TI: therapeutic index; VII: viral inhibition index. 
Several studies have tested the antimicrobial activity of macroalgal extracts obtained with different solvents. Shanab (2007) compared extracts from three macroalgae species (Sargassum dentifolium, Laurencia papillosa, and Jania corniculata) using two solvents, $\mathrm{EtOH}$ and $\mathrm{CH}_{2} \mathrm{Cl}_{2}$ [93]. Both extracts exhibited similar antimicrobial activity against all microorganisms tested (bacteria and yeasts), except against the mold Aspergillus flavus [93]. Several extracts from Gracilaria gracilis were studied to identify potential bioactive compounds [94]. $\mathrm{CHCl}_{3}$ and $\mathrm{Et}_{2} \mathrm{O}$ extracts (apolar solvents) presented lower extraction yields (\% of dry algal biomass) than extracts from more polar solvents (EtOH, $\mathrm{MeOH}$, and acetone). Less polar solvents isolated minor lipid classes (e.g., neutral and medium polar lipids) and showed lower amounts of soluble carbohydrates and total phenols than polar solvents. However, the diameter of the inhibition zones against $B$. subtilis were slightly lower in these extracts than in the extracts obtained with polar solvents (rich in soluble carbohydrates and phenolic compounds) [94]. These results suggest that although less polar solvents have lower yields, they contain compounds with interesting antibacterial features.

The lipids or lipid mixtures, their extracting solvent(s), and the methods used for their characterization in algae species are summarized in Table 3. The results of the antimicrobial assays with lipids and lipid-rich extracts from these algae are summarized in Table 4. Chemical structures of lipids isolated from algae are represented in Figure 2.

\subsubsection{Fatty Acids}

FA have been commonly reported in algae as antimicrobial agents. However, most studies tested total extracts instead of lipid-rich fractions and the antimicrobial activity was usually assigned to the most abundant FA in the extract $[96,105,116]$. The lack of target analyses limits the interpretation of the findings because FA are usually low abundant in total lipid extracts in the free form, being mainly esterified to other lipids, such as polar lipids, sterols, and triacylglycerols.

The antibacterial activity of the extracts from the microalga Dunaliella salina was suggested to be dependent on the presence of palmitic (16:0), 9,12,15-octadecatrienoic ( $\alpha$-linolenic, 18:3 n-3) and 18:1 $n-9$ together with volatile compounds [123]. The antimicrobial activity of the red macroalgae, J. corniculata, and L. papillosa, was ascribed to the presence of saturated [14:0, 16:0, stearic (18:0) acids] and the UFA [palmitoleic (16:1), 18:1 and nervonic (24:1) acids] [93]. Also, the antimicrobial activity of $S$. dentifolium was associated with the high relative abundance of 18:0, nonadecanoic (19:0), arachidic (20:0), petroselinic (18:1 $n-12)$, and 24:1 acids [93]. Plaza et al. (2010) associated the antimicrobial and antifungal activities of the alga Himanthalia elongata and the microalga Synechocystis sp. with the high amount of 16:1 n-7 and 18:1 acids in the extracts, respectively [116]. The FA 18:3 was identified as an antibacterial agent in Chaetomorpha linum against Vibrio ordalii and V. vulnificus [99]. A relationship was found among the antimicrobial activity against S. aureus, E. coli, and C. albicans, and the FA docosapentaenoic (DPA, 22:5) and triacylglycerol contents [121]. In the green macroalga Ulva rigida, purified fractions of crude extracts with the highest antibacterial activity against $S$. aureus and Enterococcus faecalis comprised mainly 16:0, 18:1, and 16:1 n-7 FA [27]. Nevertheless, most of these studies neither isolated the predominant FA nor tested its activity. The FA 16:0 was the most abundant FA in Gracilariopsis longissima's lipid extracts, that presented antibacterial activity against several Vibrio species. However, the pure FA 16:0 did not show any antibacterial activity [108]. On the other hand, some studies have isolated, purified, and characterized the FA with potential antimicrobial activity. For instance, marine diatoms revealed to be a rich source of FA with antibacterial properties. Studies with the diatom Navicula delognei allowed the isolation and identification of two FA (6Z,9Z,12Z,15Z)-hexadecatetraenoic acid (16:4 $n-1)$ and (6Z,9Z,12Z,15Z)-octadecatetraenoic acid $(18: 4 n-3)$ and an ester $(E)$-phytol(5Z,8Z,11Z,14Z,17Z)-eicosapentaenoate with potent antibacterial effect against S. typhimurium, S. aureus, and S. epidermidis [124]. Two FA with antibacterial features were isolated from the marine diatom Phaeodactylum tricornutum, (9Z)-hexadecenoic acid (16:1 n-7), and (6Z,9Z,12Z)-hexadecatrienoic acid (HTA, 16:3n-4) [125]. Both FA inhibited the growth of S. aureus and S. epidermidis [125]. Furthermore, 16:1 n-7 showed a potent antibacterial 
activity against two MRSA strains, and HTA against the Gram-negative marine bacterium Listonella anguillarum [125]. From the same diatom species, the eicosapentaenoic acid (EPA, 20:5 n-3) was isolated and tested, inhibiting the growth of Gram-negative and Gram-positive bacterial species, including MRSA [126]. The presence of double bonds in C16 FA was suggested to be crucial for their antibacterial action [125]. A higher (two-fold) inhibitory effect against S. aureus was recorded for 16:1 n-7 in relation to HTA isolated from the marine diatom P. tricornutum [125]. Nevertheless, in the macroalga Sargassum pallidum, free FA fractions having higher proportion of UFA demonstrated to be more active against more microorganisms like S. aureus, C. albicans, A. niger, and Septoria glycines [118]. Five UFA ethyl esters were isolated from the red macroalga Laurencia okamurai: (9Z,12Z,15Z,18Z,21Z)-ethyl tetracosa-9,12,15,18,21-pentaenoate, (10Z,13Z)-ethyl nonadeca-10,13-dienoate, (9Z,12Z)-ethyl nonadeca-9,12-dienoate, $(Z)$-ethyl octadec-13-enoate, and ( $Z$ )ethyl hexadec-11-enoate [109]. All FA ethyl esters revealed individual antifungal activity against Candida glabrata, four of them against Cryptococcus neoformans and two against Trichophyton rubrum [109].

Although several studies have suggested that the FA chain length and double bond position influence their antimicrobial activity, there is no unanimity on the correlation between PUFA and antimicrobial activity [127].

\subsubsection{Glycolipids}

Glycolipids are the predominant lipids in the chloroplasts' membranes of plants, eukaryotic algae, and cyanobacteria. They are recognized by their essential role in photosynthesis and by their structural functions as major components of the thylakoid membranes [128,129]. Algae synthesize two major types of glycolipids: neutral galactolipids and negatively charged sulfolipids. Neutral galactolipids include monogalactosyldiacylglycerol (MGDG), digalactosyldiacylglycerol (DGDG), and their lyso forms [monogalactosylmonoacylglycerol (MGMG), and digalactosylmonoacylglycerol (DGMG)]. Sulfolipids include SQDG and its lyso form sulfoquinovosylmonoacylglycerol (SQMG).

Glycolipids have been identified as biogenic compounds possessing a variety of bioactivities, such as antioxidant, antiviral, or antitumor [89,95,103,122,130-132]. The biological activity of glycolipids has been associated to the length of their fatty acyl chains, the number and position of the double bonds, the structure of the sugar moiety, and its anomeric configuration [131]. Gerasimenko et al. (2014) characterized the FA profiles and the antimicrobial activity of glycolipid fractions from S. pallidum throughout the year but could not assign any relationship between the amount of UFA and antimicrobial activity of DGDG, MGDG, and SGDG fractions [118]. However, a dependent effect of SFA level was observed in the antimicrobial activity of SQDG and MGDG fractions [118].

Several studies identified glycolipid fractions from algae having antimicrobial activity [89,103], even though only a few could isolate and characterize the main molecular species responsible for this activity. SQDG(20:5/16:0) was isolated from the red macroalga Gigartina tenella, which inhibited HIV-1 reverse transcriptase [107]. The sulfolipid 1-O-palmitoyl-3- $O\left(6^{\prime}\right.$-sulfo- $\alpha$-quinovopyranosyl) glycerol (SQMG 16:0) was isolated from the methanolic extract of the brown seaweed Sargassum wightii and its activity was tested against Xanthomonas oryzae pv. oryzae [120]. The sulfolipid (2S)-1,2-di-O-palmitoyl3-O-(6'-sulfo- $\alpha$-D-quinovopyranosyl) glycerol, SDGQ(16:0/16:0), from the green alga Caulerpa racemosa was found to be a potent anti-HSV-2 agent [95]. An enriched sulfolipid fraction obtained from the red macroalga Osmundaria obtusiloba demonstrated potent antiviral activity against the herpes viruses HSV-1 and HSV-2, being the SQDG(14:0/16:0) the most abundant molecular species identified in that fraction [111]. However, that sulfolipid-rich fraction had a lower antiviral activity than the crude $\mathrm{MeOH}$ fraction, maybe due to synergistic effects with other glycolipid species, such as MGDG and DGDG [97,111]. SQDG (14:0/16:0) was identified in the glycolipid-rich extracts from the brown seaweed Sargassum vulgare as the main responsible for their anti-HSV-1 and anti-HSV-2 activity [119]. Promising results were recorded in the antibacterial activity of the glycolipid-rich fraction from the brown macroalga Fucus evanescens against P. acnes, MGDG (18:3/18:3) being the main active compound [115]. The authors synthesized this glycolipid and replicated the bioassay, but its inhibition 
efficiency toward P. acnes was lower (50\%) than the glycolipid-rich fraction (>99\%) [115], suggesting a synergistic antibacterial effect with other glycolipid compounds. Additionally, the antiviral activity of SQDG and SQMG isolated from Ulva fasciata, Laurencia papillosa, Galaxoura cylindrica, Dictyota fasciola, and Taonia atomaria was shown against HSV-1. This activity was attributed to the high concentration in these glycolipids [89]. The sulfolipid fraction also demonstrated a high inhibition against E. coli and B. subtilis, being the extracts from $U$. fasciata and T. atomaria those with the highest inhibitory capacity [89]. The potent antiviral effect of sulfolipids has been related with the negative charge of their sulfonate group as verified for marine polysaccharides [133].

Glycolipids from the red alga Chondria armata were recognized by their antibacterial and antifungal activities against several pathogens, such as C. albicans and C. neoformans or Klebsiella sp. [104]. The main bioactive lipid from the glycolipid fraction was identified as 1-eicosapentanoyl-2-palmitoyl-3-Ogalactopyranosyl-glycerol, MGDG(20:5/16:0) [104]. The isolated fractions of MGDG and SQDG obtained from the lipophilic fractions of the brown seaweed Laminaria cichorioides inhibited the growth of the yeast Safale and C. albicans, the fungi A. niger and F. oxysporum, and the bacteria S. aureus and E. coli [91].

Several studies demonstrated higher antimicrobial activity in lipid-rich fractions than in total lipid extracts $[91,118]$. In the brown seaweed S. pallidum, the isolated fractions of glycolipids and free FA demonstrated to be more efficient in inhibiting bacterial growth than the total lipid extract [118]. The antimicrobial activity efficiency may be conditioned by seasonal variation, that must be related with shifts in the lipid profiles promoted by alterations in growth-related environmental conditions [118]. Nevertheless, a seasonal variation was not always verified, like in the green seaweed $U$. rigida that demonstrated a uniform antimicrobial activity throughout the year [27].

\subsubsection{Other Lipids}

The exploration of algal lipidomes has revealed a panoply of compounds with antimicrobial activity. Two compounds with antiviral properties against Semeliki forest and Japanese encephalitis viruses were isolated from $U$. fasciata's lipophilic fractions, a sphingosine ( $N$-palmitoyl-2-amino-1,3,4,5tetrahydroxyoctadecane) and a ceramide (erythro-sphinga-4,8-dienine- $N$-palmitate), respectively [101,102]. Two bromoditerpenes, with antibacterial and antimalarial activity against $S$. aureus and the chloroquine-resistant $P$. falciparum, respectively, were isolated from the red alga Sphaerococcus coronopifolius [114]. Four halogenated sesquiterpenes isolated from the surface of the red macroalga Laurencia spp. demonstrated antibacterial activities toward six Gram-negative bacteria such as V. parahaemolyticus, Chromobacterium violaceum, or Erwinia sp. Neophytadiene and phytol were identified in the microalga $D$. salina as putative antimicrobial compounds against E. coli, S. aureus, C. albicans, and A. niger [123]. Several terpenes isolated from the brown seaweeds Sargassum fusiforme and $S$. vulgare were identified as putative antimicrobial molecules against clinical bacteria [117]. Terpenes were also suggested as antibacterial compounds against MRSA and E. coli in the red seaweeds Caulerpa racemosa and Caulerpa lentillifera [96].

Clerosterol was the main compound identified in a bioactive fraction from the green seaweed Codium amplivesiculatum against Gram-positive (S. aureus) and Gram-negative (V. parahaemolyticus) bacteria [100]. However, this compound did not display antibacterial activity when tested alone [100]. Different phospholipid classes, such as phosphatidylethanolamine and phosphatidylserine were identified in the red seaweed Pyropia orbicularis, as putative antimicrobial compounds, together with MGDG [113].

\subsubsection{Photosynthetic Pigments}

Pigments are not recognized as lipids, but they are present in the total lipid extracts of algae since they are extracted from the biomass along with lipids. Besides, in most studies, they were not removed from the lipid extracts. Pigments are mainly recognized by their antioxidant activity [134,135], but some studies have attributed a weak antibacterial activity to photosynthetic pigments such as chlorophylls 
and carotenoids [93]. Pheophytin $\alpha$ and chlorophyllide $\alpha$ from the microalga Isochrysis galbana were found to have a high antibacterial activity against marine strains of Brevibacterium and Micrococcus [136]. Carotenoid derivatives ( $\beta$-cyclocitral and $\alpha$ - and $\beta$-ionone) from the microalga $D$. salina extracts were suggested to be responsible for its antimicrobial activity [123]. Fucoxanthin-rich fractions from the brown macroalga L. cichorioides demonstrated weak activity against yeast (Safale and C. albicans) and bacteria (S. aureus and E. coli), while chlorophyll fractions showed antibacterial activity against S. aureus and E. coli [91]. Photosynthetic pigments isolated from the brown macroalga S. pallidum's extracts presented antifungal and antibacterial activities, chlorophylls (chlorophyll $\alpha$ as the main component) being the mediator to inhibit the growth of the fungi S. glycines and A. niger, while fucoxanthin was effective against $E$. coli [118].

\subsection{Marine Invertebrates}

The chemotaxonomic diversity of marine invertebrates is responsible for the large number of novel compounds identified in their phyla. Tropical biodiversity-rich benthic communities have been the most explored, thus the most fruitful in the identification of new potential antimicrobial compounds [137-139]. However, less conventional environments such as the Arctic ocean or mesopelagic communities have been started to be surveyed $[140,141]$.

Marine invertebrates comprise a growing source of natural compounds, showing novel structures for biomedical and health-promoting applications [142]. Bioprospection of new compounds from marine invertebrates has revealed to be a prolific work to discover diverse bioactive compounds with action toward a broad spectrum of microorganisms [140,143]. Some of these reports have identified total lipid extracts as a potential source of bioactive compounds, lacking a sequential workflow of isolation, characterization, and purification of the metabolites responsible for the activity $[99,143]$. Although most of these studies used classical bioprospection methods to identify the bioactive compounds from marine species, others followed eco-friendly approaches by using fishing waste [141] or seafood by-products [144].

Phyla of marine invertebrates recognized as sources of antimicrobial compounds $[16,145]$ include porifera [146,147], crustacean [148,149], mollusk [144,150,151], or cnidaria [137,139]. Some bacteria isolated from marine organisms have also disclosed antibacterial activity, such as Actinobacteria from sponges [26].

The main antibacterial natural products identified in marine invertebrates were peptides, polyketides, alkaloids, terpenes, and lipopeptides [14,34,150,152]. However, several antimicrobial lipids classes have been identified. Marine invertebrates produce an array of unique lipids originating from unusual biosynthetic pathways that are not common in other environments, as a result of thriving in diverse and extreme environments [142,153].

Porifera represents the most studied phylum of marine invertebrates for antimicrobial compounds' bioprospection, including lipids $[154,155]$. The high contribution of these ancestral metazoans for bioactive compounds' research seems to be related to their high filtering activity, pumping water during feeding, which expose them to viruses, bacteria, and eukaryotic organisms (pathogenic and non-pathogenic) [156,157].

Table 5 assembles the information regarding lipids from marine invertebrate species having antimicrobial activity. Table 6 summarizes the information about the antimicrobial properties, the tested organisms, and the antimicrobial assays for each marine invertebrates' species listed in Table 5 . Figure 2 illustrates the chemical structure of the main lipid classes with antimicrobial properties from these natural sources. 


\subsubsection{Fatty Acids}

FA identified in marine invertebrates display a high diversity of chemical structures that are scarce or inexistent in other environments, such as very long chain PUFA or cyclic forms [158-160]. A C14 acetylenic FA isolated from the sponge Oceanapia sp. revealed antimicrobial activity against nine microbial strains, including yeasts and the bacteria E. coli, P. aeruginosa, B. subtilis, and S. aureus [161]. Complex FA mixtures containing very long chain FA were isolated from the sponge Agelas oroides and tested as anti-infectious agents [162]. These FA inhibited the enoyl reductases, enzymes that catalyze the last step of the elongation cycle in FA synthesis, in P. falciparum, M. tuberculosis, and E. coli [162]. An acetylenic FA having antibacterial activity against $S$. aureus and $E$. coli was discovered in the marine sponge Paragrantia cf. waguensis [163]. Ravichandran et al. (2010) suggested 18:1 and 18:2 FA as antimicrobial compounds from the hemolymph and hemocytes of brachyuran crabs with greatest activity against $V$. cholerae, S. flexneri, S. pyogenes, and E. coli [148]. Brominated FA from a sponge of the genus Xestospongia showed antimicrobial activity against MRSA, S. mutans, and S. sobrinus [138]. Anti-infective brominated long-chain acids, termed motualevic acids, and an enantiomer of antazirine, were isolated from the sponge Siliquariaspongia sp. with activity against S. aureus and MRSA [164]. A recent study screening mesopelagic species as a source of potential antimicrobial compounds recognized the extracts of the lanternfish Myctophum punctatum and the Mediterranean krill Meganyctiphanes norvegica to inhibit the growth of MRSA, MSSA, and M. tuberculosis [141]. Extracts of both marine species were fractionated, and their composition was elucidated by LC-UV analysis. EPA, 4,7,10,13,16,19-docosahexaenoate (DHA, 22:6n-3) and 8,11,14,17-eicosatetraenoic (ETA, 20:4n-3) acids were the most abundant components in the lipid fractions of both marine species [141]. The 14-methyl-5,9-pentadecadienoic FA from the phospholipid pool was isolated and identified in the gorgonian coral Eunicea succinea and it was active against S. aureus and E. faecalis [137]. Quantitative data on antimicrobial efficiency are shown in Table 6. 
Table 5. Marine invertebrate lipids or lipid-rich extracts with antimicrobial potential, their origin and extraction method.

\begin{tabular}{|c|c|c|c|c|c|c|}
\hline Scientific Name & $\begin{array}{l}\text { Phylum } \\
\text { (Class) }\end{array}$ & Collection Site & Extracting Solvent(s)/Method & $\begin{array}{l}\text { Isolated Lipids or } \\
\text { Lipid Classes }\end{array}$ & $\begin{array}{l}\text { Compound } \\
\text { Identification } \\
\text { Methods }\end{array}$ & Ref. \\
\hline \multirow[b]{2}{*}{ Acanthodendrilla sp. } & $\begin{array}{c}\text { Porifera } \\
\text { (Demospongiae) }\end{array}$ & $\begin{array}{c}\text { Gokasho Bay, Tokyo, } \\
\text { Japan }\end{array}$ & $\begin{array}{l}\mathrm{MeOH} \text {. Aqueous residue extracted } \\
\text { with } \mathrm{Et}_{2} \mathrm{O} \text { and } n \text { - } \mathrm{BuOH} \text {. Organic } \\
\text { extract fractionated by } \mathrm{SiO}_{2} \\
\left(\mathrm{MeOH} / \mathrm{CHCl}_{3}\right) \text {, purified by ODS } \\
\text { column and C18 RP HPLC }\end{array}$ & Steroid sulfates & ${ }^{1} \mathrm{H}$ and ${ }^{13} \mathrm{C}$ NMR & [169] \\
\hline & $\begin{array}{c}\text { Porifera } \\
\text { (Demospongiae) }\end{array}$ & $\begin{array}{l}\text { Kundingarengkeke } \\
\text { Island, Indonesia }\end{array}$ & $\begin{array}{l}\text { EtOH, acetone and } \mathrm{MeOH} \text {. Crude } \\
\text { extract partitioned between aqueous } \\
\mathrm{MeOH} \text { and hexane, EtOAc, and } \\
\mathrm{BuOH} \text {. Hexane extract fractionated } \\
\text { on normal-phase } \mathrm{SiO}_{2} \text { column } \\
(n \text {-hexane/EtOAc, } 7: 3, v / v) . \\
\text { Purification by semi-preparative } \\
\text { HPLC }\end{array}$ & $\begin{array}{l}\text { Sesterterpenes } \\
\text { (Luffariellolide } \\
\text { derivatives, } \\
\text { Acantholides) }\end{array}$ & $\begin{array}{l}{ }^{1} \mathrm{H} \text { and }{ }^{13} \mathrm{C} \text { NMR, } \\
\text { ESI-MS, HR-EI-MS }\end{array}$ & [190] \\
\hline Agelas oroides & $\begin{array}{c}\text { Porifera } \\
\text { (Demospongiae) }\end{array}$ & $\begin{array}{l}\text { Gökçeada, Northern } \\
\text { Aegean Sea, } \\
\text { Turkey }\end{array}$ & $\begin{array}{c}\mathrm{MeOH}, \mathrm{MeOH} \mathrm{CHCl}_{3}(1: 1, v / v) \text { and } \\
\mathrm{CHCl} \text {. Extract dissolved in } \\
\mathrm{MeOH} / \mathrm{H}_{2} \mathrm{O}(9: 1, v / v) \text { partitioned } \\
\text { against } n \text {-hexane. } n \text {-hexane, } \mathrm{CH}_{3} \mathrm{Cl} \\
\text { and } \mathrm{MeOH} \text { extracts fractionated on } \\
\mathrm{SiO}_{2} \text { (EtOAc }(0 \rightarrow 100 \%) \text { in hexane). } \\
\text { Sephadex LH20 and C18 flash } \\
\text { column }\end{array}$ & FA & $\begin{array}{c}{ }^{1} \mathrm{H} \text { and }{ }^{13} \mathrm{C} \mathrm{NMR}, 1 \mathrm{D} \\
\text { and } 2 \mathrm{D} \text { NMR, GC-MS, } \\
\text { ESI-MS }\end{array}$ & [162] \\
\hline \multirow[t]{2}{*}{ Caminus sphaeroconia } & \multirow[t]{2}{*}{$\begin{array}{c}\text { Porifera } \\
\text { (Demospongiae) }\end{array}$} & Dominica & $\begin{array}{l}\text { MeOH extracts chromatographed on } \\
\text { Sepahdex } \mathrm{LH} 20(\mathrm{MeOH} \text { and } \\
\left.\text { EtOAc/MeOH/H} \mathrm{H}_{2} \mathrm{O} 20: 5: 2\right) \text {. } \\
\text { Purification by gradient on } \mathrm{SiO}_{2} \\
\left(\mathrm{CH}_{2} \mathrm{Cl}_{2} \text { to } \mathrm{CH}_{2} \mathrm{Cl}_{2} / \mathrm{MeOH} 9: 1, v / v\right)\end{array}$ & $\begin{array}{c}\text { Glycolipid } \\
\text { (Caminoside) }\end{array}$ & $\begin{array}{c}{ }^{1} \mathrm{H} \text { and }{ }^{13} \mathrm{C} \text { NMR, } \\
\text { ESI-MS }\end{array}$ & [147] \\
\hline & & Dominica & $\begin{array}{l}\text { MeOH extract purified by Sephadex } \\
\mathrm{LH}-20(\mathrm{MeOH}) . \text { Sephadex LH-20 } \\
\left(\mathrm{EtOAc} / \mathrm{MeOH} / \mathrm{H}_{2} \mathrm{O}(20: 5: 2, v / v)\right)\end{array}$ & $\begin{array}{c}\text { Glycolipid } \\
\text { (Caminoside) }\end{array}$ & $\begin{array}{c}{ }^{1} \mathrm{H} \text { and }{ }^{13} \mathrm{C} \mathrm{NMR}, \\
\text { ESI-MS }\end{array}$ & [176] \\
\hline
\end{tabular}


Table 5. Cont.

\begin{tabular}{|c|c|c|c|c|c|c|}
\hline Scientific Name & $\begin{array}{l}\text { Phylum } \\
\text { (Class) }\end{array}$ & Collection Site & Extracting Solvent(s)/Method & $\begin{array}{l}\text { Isolated Lipids or } \\
\text { Lipid Classes }\end{array}$ & $\begin{array}{l}\text { Compound } \\
\text { Identification } \\
\text { Methods }\end{array}$ & Ref. \\
\hline Dysidea arenaria & $\begin{array}{c}\text { Porifera } \\
\text { (Demospongiae) }\end{array}$ & $\begin{array}{l}\text { Hainan Island, South } \\
\text { China Sea, China }\end{array}$ & $\begin{array}{c}\mathrm{CHCl}_{3} \text {-soluble portion was } \\
\text { repartitioned between petroleum } \\
\text { ether and } 90 \% \text { MeOH. MeOH extract } \\
\text { on flash } \mathrm{SiO}_{2} \text { column (ether/EtOAc } \\
\text { gradient) }\end{array}$ & $\begin{array}{l}\text { Sesquiterpenoid } \\
\text { (Sesquiterpenoid } \\
\text { hydroquinone) }\end{array}$ & $\begin{array}{l}{ }^{1} \mathrm{H} \text { and }{ }^{13} \mathrm{C}-\mathrm{NMR}, \\
\text { ESI-MS }\end{array}$ & [184] \\
\hline Dysidea sp. & $\begin{array}{c}\text { Porifera } \\
\text { (Demospongiae) }\end{array}$ & $\begin{array}{l}\text { Lakshadweep Islands, } \\
\text { Kerala, India }\end{array}$ & $\begin{array}{l}\text { EtOAc and } \mathrm{MeOH} \text {. EtOAc extract } \\
\text { chromatographed on Sephadex } \\
\mathrm{LH} 20\left(\mathrm{MeOH} / \mathrm{CHCl}_{3}, 1: 1, v / v\right), \mathrm{SiO}_{2} \\
(2 \% \text { EtOAc petroleum ether })\end{array}$ & $\begin{array}{l}\text { Sesterterpenes } \\
\text { (Sesterterpene } \\
\text { sulfates) }\end{array}$ & $\begin{array}{c}{ }^{1} \mathrm{H} \text { and }{ }^{13} \mathrm{C} \text { NMR, } \\
\text { HR-FAB-MS }\end{array}$ & [183] \\
\hline Erylus lendenfeldi & $\begin{array}{c}\text { Porifera } \\
\text { (Demospongiae) }\end{array}$ & Gulf of Eilat, Red Sea & $\begin{array}{c}\mathrm{MeOH} / \mathrm{CHCl}_{3}, \mathrm{RP} \text { on a } \mathrm{C} 18 \text { column } \\
\text { (decreasing percentage of } \mathrm{H}_{2} \mathrm{O} \text { in } \\
\mathrm{MeOH} \text { ) }\end{array}$ & $\begin{array}{l}\text { Steroidal glycoside } \\
\quad \text { (Eryloside) }\end{array}$ & $\begin{array}{c}{ }^{1} \mathrm{H} \text { and }{ }^{13} \mathrm{C} \text { NMR, UV, } \\
\text { IR }\end{array}$ & [172] \\
\hline Erylus placenta & $\begin{array}{c}\text { Porifera } \\
\text { (Demospongiae) }\end{array}$ & Hachijo Island, Japan & $\begin{array}{c}n \text {-PrOH} / \mathrm{H}_{2} \mathrm{O}(3: 1, v / v) \text {. Extracts } \\
\text { partitioned between } \mathrm{H}_{2} \mathrm{O} \text { and } \mathrm{CHCl}_{3} \text {. } \\
\mathrm{H}_{2} \mathrm{O} \text { layer partitioned between } \\
n \text { - } \mathrm{BuOH} \text { and } \mathrm{H}_{2} \mathrm{O} \text {. BuOH fraction } \\
\text { separated by } \mathrm{C} 18 \text { flash }\left(n-\mathrm{PrOH} / \mathrm{H}_{2} \mathrm{O}\right. \\
(1: 9,3: 7,5: 5 \text {, and } 8: 2, v / v) \text { and } \\
\left.\mathrm{CHCl}_{3} / \mathrm{MeOH} / \mathrm{H}_{2} \mathrm{O}(6: 4: 1, v / v)\right)\end{array}$ & $\begin{array}{l}\text { Steroidal glycoside } \\
\text { (Sokodosides) }\end{array}$ & $\begin{array}{c}{ }^{1} \mathrm{H} \text { and }{ }^{13} \mathrm{C} \text { NMR, } \\
\text { GC-FID, UV }\end{array}$ & [174] \\
\hline Euryspongia sp. & $\begin{array}{c}\text { Porifera } \\
\text { (Demospongiae) }\end{array}$ & $\begin{array}{l}\text { Light House Reef, } \\
\text { Koror, Palau }\end{array}$ & $\begin{array}{l}\text { MeOH. Extracts fractionated by } \\
\text { HP20SS column (acetone } / \mathrm{H}_{2} \mathrm{O} \text { ) }\end{array}$ & $\begin{array}{l}\text { Steroid sulfates } \\
\text { (Eurysterols) }\end{array}$ & $\begin{array}{l}{ }^{1} \mathrm{H} \text { and }{ }^{13} \mathrm{C} \mathrm{NMR}, \\
\text { ESI-MS, UV, IR }\end{array}$ & [167] \\
\hline Fasciospongia sp. & $\begin{array}{c}\text { Porifera } \\
\text { (Demospongiae) }\end{array}$ & $\begin{array}{l}\text { Cape Leeuwin, } \\
\text { Western Australia }\end{array}$ & $\begin{array}{l}\text { EtOH extract partitioned into } \\
n \text {-BuOH and } \mathrm{H}_{2} \mathrm{O} \text { soluble fractions. } \\
n \text { - } \mathrm{BuOH} \text { fraction subsequently } \\
\text { defatted by sequential trituration in } \\
n \text {-hexane and } \mathrm{CH}_{2} \mathrm{Cl}_{2} \text { soluble } \\
\text { fractions. } \mathrm{CH}_{2} \mathrm{Cl}_{2} \text { fractions subjected } \\
\text { to SPE or HLPC }\end{array}$ & $\begin{array}{l}\text { Meroterpene } \\
\text { (Meroterpene sulfate } \\
\text { fascioquinol) }\end{array}$ & $\begin{array}{l}{ }^{1} \mathrm{H} \text { and }{ }^{13} \mathrm{C} \text { NMR, } \\
\text { HR-ESI-MS, UV }\end{array}$ & [186] \\
\hline
\end{tabular}


Table 5. Cont.

\begin{tabular}{|c|c|c|c|c|c|c|}
\hline Scientific Name & $\begin{array}{l}\text { Phylum } \\
\text { (Class) }\end{array}$ & Collection Site & Extracting Solvent(s)/Method & $\begin{array}{l}\text { Isolated Lipids or } \\
\text { Lipid Classes }\end{array}$ & $\begin{array}{l}\text { Compound } \\
\text { Identification } \\
\text { Methods }\end{array}$ & Ref. \\
\hline \multirow[b]{2}{*}{ Halichondria sp. } & $\begin{array}{c}\text { Porifera } \\
\text { (Demospongiae) }\end{array}$ & $\begin{array}{c}\text { Unten Port, Okinawa, } \\
\text { Japan }\end{array}$ & $\begin{array}{c}\text { Methanolic extract partitioned } \\
\text { between } \mathrm{H}_{2} \mathrm{O} \text { and EtOAc. EtOAc } \\
\text { soluble material subjected to } \mathrm{SiO}_{2} \\
\text { column }\left(\mathrm{CHCl}_{3} / \mathrm{MeOH},(95: 5, v / v)\right. \\
\left.\text { and petroleum ether/Et }{ }_{2} \mathrm{O}(9: 1, v / v)\right)\end{array}$ & $\begin{array}{l}\text { Sesquiterpenoids } \\
\text { (Halichonadins) }\end{array}$ & $\begin{array}{c}{ }^{1} \mathrm{H} \text { and }{ }^{13} \mathrm{C} \text { NMR, } \\
\text { EI-MS, IR }\end{array}$ & [187] \\
\hline & $\begin{array}{c}\text { Porifera } \\
\text { (Demospongiae) }\end{array}$ & & 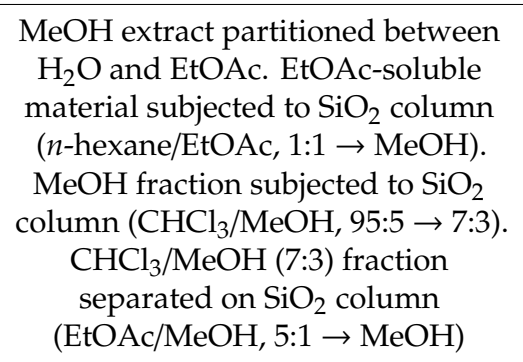 & $\begin{array}{l}\text { Sesquiterpenoid } \\
\text { (Halichonadins) }\end{array}$ & $\begin{array}{c}{ }^{1} \mathrm{H} \text { and }{ }^{13} \mathrm{C} \text { NMR, } \\
\text { ESI-MS, HR-ESI-MS, } \\
\text { IR }\end{array}$ & [188] \\
\hline Haliclona simulans & $\begin{array}{c}\text { Porifera } \\
\text { (Demospongiae) }\end{array}$ & $\begin{array}{l}\text { Kilkieran Bay, } \\
\text { Galway, Ireland }\end{array}$ & $\begin{array}{c}\text { Acetone and } \mathrm{MeOH} \text { extracts } \\
\text { subjected to } \mathrm{HP} 20 \text { chromatography } \\
\left(100 \% \mathrm{H}_{2} \mathrm{O} \rightarrow 100 \% \mathrm{MeOH}\right) \\
\text { Fractionated on flash forward } \\
\text { system. } \mathrm{SiO}_{2} \text { column }(100 \% \text { hexane } \\
\quad \rightarrow 100 \% \text { EtOAc) }\end{array}$ & $\begin{array}{c}\text { Steroids } \\
\text { (24-vinyl-cholest-9- } \\
\text { ene-3 } \beta, 24 \text {-diol, } \\
\text { 20-methyl-pregn-6- } \\
\text { en-3 } \beta \text {-ol, } 5 \alpha, 8 \alpha \text {-epidioxy, } \\
\text { 24-methylenecholesterol) }\end{array}$ & $\begin{array}{l}{ }^{1} \mathrm{H}-\text { and }{ }^{13} \mathrm{C} \text { NMR, } \\
\text { GC-MS }\end{array}$ & [170] \\
\hline Jaspis stellifera & $\begin{array}{c}\text { Porifera } \\
\text { (Demospongiae) }\end{array}$ & $\begin{array}{l}\text { Ishigaki Island, } \\
\text { Okinawa, Japan }\end{array}$ & $\begin{array}{c}\mathrm{MeOH} \text {. EtOAc soluble material } \\
\text { subjected to } \mathrm{SiO}_{2} \text { column } \\
\left(\mathrm{CHCI}_{3} / \mathrm{MeOH}, 9: 1 \text { and }\right. \\
\text { hexane/EtOAc, 3:7, v/v). } \\
\text { EtOAc-soluble material subjected to } \\
\mathrm{SiO}_{2} \text { columns and } \mathrm{C} 18 \text { HPLC }\end{array}$ & $\begin{array}{l}\text { Nortriterpenoids } \\
\text { (Jaspiferals) }\end{array}$ & $\begin{array}{c}{ }^{1} \mathrm{H} \text { and }{ }^{13} \mathrm{C} \text { NMR, } \\
\text { EI-MS, UV, IR }\end{array}$ & [181] \\
\hline Luffariella geometrica & $\begin{array}{c}\text { Porifera } \\
\text { (Demospongiae) }\end{array}$ & $\begin{array}{l}\text { Great Australian } \\
\text { Bight, Australia }\end{array}$ & $\begin{array}{l}\mathrm{CH}_{2} \mathrm{Cl}_{2} \text {. Sequential fractionation to } \\
\text { obtain pure compounds }\end{array}$ & $\begin{array}{l}\text { Sesterterpenes } \\
\text { (Luffarins) }\end{array}$ & $\begin{array}{l}{ }^{1} \mathrm{H} \text { and }{ }^{13} \mathrm{C} \text { NMR, } \\
\text { EI-MS, UV, IR }\end{array}$ & [178] \\
\hline
\end{tabular}


Table 5. Cont.

\begin{tabular}{|c|c|c|c|c|c|c|}
\hline Scientific Name & $\begin{array}{l}\text { Phylum } \\
\text { (Class) }\end{array}$ & Collection Site & Extracting Solvent(s)/Method & $\begin{array}{l}\text { Isolated Lipids or } \\
\text { Lipid Classes }\end{array}$ & $\begin{array}{l}\text { Compound } \\
\text { Identification } \\
\text { Methods }\end{array}$ & Ref. \\
\hline \multirow{2}{*}{ Luffariella variabilis } & \multirow{2}{*}{$\begin{array}{c}\text { Porifera } \\
\text { (Demospongiae) }\end{array}$} & $\begin{array}{c}\text { Western Carolines, } \\
\text { Palau }\end{array}$ & $\begin{array}{c}\mathrm{CH}_{2} \mathrm{Cl}_{2} \text {, purified by } \\
\text { chromatography }\end{array}$ & $\begin{array}{l}\text { Sesterterpenoids } \\
\text { (Manoalide) }\end{array}$ & $\begin{array}{c}{ }^{1} \mathrm{H} \text { and }{ }^{13} \mathrm{C} \text { NMR, UV, } \\
\text { IR }\end{array}$ & [180] \\
\hline & & $\begin{array}{c}\text { Western Carolines, } \\
\text { Palau }\end{array}$ & $\begin{array}{l}\mathrm{CH}_{2} \mathrm{Cl}_{2} \text {, purified by } \\
\text { chromatography }\end{array}$ & $\begin{array}{l}\text { Sesterterpenoids } \\
\text { (Manoalides) }\end{array}$ & $\begin{array}{c}{ }^{1} \mathrm{H} \text { and }{ }^{13} \mathrm{C} \mathrm{NMR}, \mathrm{UV}, \\
\mathrm{IR}\end{array}$ & [179] \\
\hline Melophlus sarasinorum & $\begin{array}{c}\text { Porifera } \\
\text { (Demospongiae) }\end{array}$ & $\begin{array}{l}\text { Makassar, Sulawesi } \\
\text { Island, Indonesia }\end{array}$ & $\begin{array}{c}\text { Acetone and } \mathrm{MeOH} \text {. Extract } \\
\text { partitioned between EtOAc and } \mathrm{H}_{2} \mathrm{O} \text {. } \\
\text { Aqueous extract on } \mathrm{HP} 20(\mathrm{MeOH}, \\
\left.\mathrm{H}_{2} \mathrm{O}\right) . \mathrm{MeOH} \text { eluate on } \mathrm{C} 18(\mathrm{MeOH} \\
\text { and } \mathrm{H}_{2} \mathrm{O} \text {, gradient elution) }\end{array}$ & $\begin{array}{l}\text { Steroidal glycosides } \\
\text { (Sarasinoside) }\end{array}$ & $\begin{array}{c}{ }^{1} \mathrm{H} \text { and }{ }^{13} \mathrm{C} \text { NMR, } \\
\text { HR-ESI-MS, LC-MS, } \\
\text { UV }\end{array}$ & [173] \\
\hline Oceanapia sp. & $\begin{array}{c}\text { Porifera } \\
\text { (Demospongiae) }\end{array}$ & $\begin{array}{l}\text { Kamagi Bay, Sada } \\
\text { Peninsula, Japan }\end{array}$ & $\begin{array}{l}\mathrm{MeOH} \text { extracts partitioned between } \\
\text { ether and } \mathrm{H}_{2} \mathrm{O} \text {. Organic phase } \\
\text { partitioned between } n \text {-hexane and } \\
\mathrm{MeOH} / \mathrm{H}_{2} \mathrm{O}(9: 1, v / v) \text {. Aqueous } \\
\mathrm{MeOH} \text { fraction subjected to } \mathrm{C} 18 \text {. } \\
\text { Purification on } \mathrm{SiO}_{2} \text { column }\left(\mathrm{CHCl}_{3} \text {, }\right. \\
\mathrm{CHCl} / \mathrm{MeOH}(9: 1) \text {, } \\
\mathrm{CHCl}_{3} / \mathrm{MeOH}^{-} \mathrm{H}_{2} \mathrm{O}(6: 4: 1) \text {, and } \\
\mathrm{MeOH})\end{array}$ & Acetylenic acid & $\begin{array}{l}{ }^{1} \mathrm{H} \text { and }{ }^{13} \mathrm{C} \text { NMR, } \\
\text { FAB-MS, UV, IR }\end{array}$ & [161] \\
\hline $\begin{array}{l}\text { Paragrantia cf. } \\
\text { waguensis }\end{array}$ & Porifera (Calcarea) & $\begin{array}{l}\text { Onna village, } \\
\text { Okinawa, Japan }\end{array}$ & $\begin{array}{l}\mathrm{MeOH} \text { extract partitioned between } \\
\mathrm{H}_{2} \mathrm{O} \text { and EtOAc. EtOAc extract } \\
\text { subjected to Sephadex LH20 } \\
\left(\mathrm{CH}_{2} \mathrm{Cl}_{2} / \mathrm{MeOH}, 1: 1, v / v\right) \text {. Fraction } \\
\text { separation on RP HPLC }\end{array}$ & Acetylenic acid & $\begin{array}{c}{ }^{1} \mathrm{H} \text { and }{ }^{13} \mathrm{C} \text { NMR, } \\
\text { ESI-MS, UV, IR }\end{array}$ & [163] \\
\hline Petrosia weinbergi & $\begin{array}{c}\text { Porifera } \\
\text { (Demospongiae) }\end{array}$ & $\begin{array}{l}\text { Acklin Island, } \\
\text { Bahamas }\end{array}$ & $\begin{array}{c}\mathrm{MeOH} / \mathrm{CHCl}_{3}(1: 1, v / v) . \text { Aqueous } \\
\text { suspension extracted with EtOAc, } \\
\text { EtOAc/ } n \text {-BuOH }(1: 1) \text {, and } n \text {-BuOH. } \\
\text { Active extracts fractionated by C18 } \\
\text { HPLC }\end{array}$ & $\begin{array}{l}\text { Steroid sulfates } \\
\text { (Weinbersterol } \\
\text { disulfates) }\end{array}$ & $\begin{array}{c}{ }^{1} \mathrm{H} \text { and }{ }^{13} \mathrm{C} \text { NMR, } \\
\text { FAB-MS, IR }\end{array}$ & [166] \\
\hline
\end{tabular}


Table 5. Cont.

\begin{tabular}{|c|c|c|c|c|c|c|}
\hline Scientific Name & $\begin{array}{l}\text { Phylum } \\
\text { (Class) }\end{array}$ & Collection Site & Extracting Solvent(s)/Method & $\begin{array}{l}\text { Isolated Lipids or } \\
\text { Lipid Classes }\end{array}$ & $\begin{array}{l}\text { Compound } \\
\text { Identification } \\
\text { Methods }\end{array}$ & Ref. \\
\hline $\begin{array}{l}\text { Poecillastra wondoensis, } \\
\text { Rhabdastrella } \\
\text { wondoensis } \\
\text { (two-sponge } \\
\text { association) }\end{array}$ & $\begin{array}{c}\text { Porifera } \\
\text { (Demospongiae) }\end{array}$ & $\begin{array}{c}\text { Cheju Island, South } \\
\text { Korea }\end{array}$ & $\begin{array}{c}\mathrm{MeOH}(70 \%) \text {. Extract partitioned } \\
\text { with } \mathrm{Et}_{2} \mathrm{O} \text { and } \mathrm{H}_{2} \mathrm{O} \text {. Aqueous phase } \\
\text { extracted with } n-\mathrm{BuOH} \text {, subjected to } \\
\mathrm{C} 18 \text { flash chromatography and } \\
\text { Sephadex LH-20. Purification on } \\
\text { C18 HPLC }\end{array}$ & $\begin{array}{l}\text { Steroidal glycosides } \\
\text { (Wondosterols) }\end{array}$ & $\begin{array}{l}{ }^{1} \mathrm{H} \text { and }{ }^{13} \mathrm{C} \text { NMR, } \\
\text { FAB-MS, UV, IR }\end{array}$ & [175] \\
\hline $\begin{array}{l}\text { Pseudoceratina } \\
\text { purpurea }\end{array}$ & $\begin{array}{c}\text { Porifera } \\
\text { (Demospongiae) }\end{array}$ & $\begin{array}{c}\text { Kaunakakai Harbor, } \\
\text { O'ahu island, Hawaii, } \\
\text { USA }\end{array}$ & $\begin{array}{l}\text { EtOH and methylene chloride. } \\
\text { Combined extracts partitioned } \\
\text { (hexane, methylene chloride and } \\
\text { BuOH) Isolation: } \mathrm{SiO}_{2} \text { flash column } \\
\text { (hexane). Purification: Sephadex } \\
\text { LH-20 }\end{array}$ & $\begin{array}{c}\text { Bromotyramine } \\
\text { homoserine-derived } \\
\text { (Mololipids) }\end{array}$ & $\begin{array}{l}{ }^{1} \mathrm{H} \text { and }{ }^{13} \mathrm{C} \text { NMR, } \\
\text { HR-FAB-MS, UV, IR }\end{array}$ & [191] \\
\hline Axinyssa digitata & $\begin{array}{c}\text { Porifera } \\
\text { (Demospongiae) }\end{array}$ & Tunisia & $\begin{array}{c}\text { Acetone extract partitioned between } \\
\mathrm{H}_{2} \mathrm{O} \text { and } \mathrm{Et}_{2} \mathrm{O} \text {. Aqueous residue } \\
\text { re-extracted with } n \text {-BuOH and } \\
\text { chromatographed on Sephadex } \\
\text { LH-20 column (MeOH) and C18 } \\
\text { HPLC }\end{array}$ & $\begin{array}{c}\text { Steroid sulfates } \\
\text { (Halistanol sulfates) }\end{array}$ & $\begin{array}{c}{ }^{1} \mathrm{H} \text { and }{ }^{13} \mathrm{C} \text { NMR, } \\
\text { FAB-MS }\end{array}$ & [165] \\
\hline Siliquariaspongia sp. & $\begin{array}{c}\text { Porifera } \\
\text { (Demospongiae) }\end{array}$ & Motualevu reef, Fiji & $\begin{array}{c}\mathrm{H}_{2} \mathrm{O} \text { and } \mathrm{MeOH} / \mathrm{CH}_{2} \mathrm{Cl}_{2}(1: 1, v / v) . \\
n \text {-BuOH-soluble material from the } \\
\text { aqueous extract and } \mathrm{CHCl}_{3} \text {-soluble } \\
\text { material from the organic extract } \\
\text { chromatographed on Sephadex } \\
\left.\text { LH-20 (MeOH/H} / \mathrm{H}_{2} \mathrm{O}, 3: 1, v / v\right) . \\
\text { Purification by RP HPLC }\end{array}$ & $\begin{array}{c}\text { Brominated } \\
\text { long-chain acids } \\
\text { (Motualevic acids) }\end{array}$ & $\begin{array}{c}{ }^{1} \mathrm{H}-\text { and }{ }^{13} \mathrm{C}-\mathrm{NMR}, \\
\text { LC-MS, HR-ESI-MS, } \\
\text { FT-IR }\end{array}$ & [164] \\
\hline $\begin{array}{l}\text { Siphonodictyon } \\
\text { coralliphagum }\end{array}$ & $\begin{array}{c}\text { Porifera } \\
\text { (Demospongiae) }\end{array}$ & $\begin{array}{l}\text { Lighthouse Reef and } \\
\text { Glover Reef, Belize }\end{array}$ & $\begin{array}{l}\text { EtOH. Aqueous suspension } \\
\text { extracted with } \mathrm{CH}_{2} \mathrm{Cl}_{2} \text {, EtOAc and } \\
n \text {-BuOH. EtOAc extract fractionated } \\
\text { by chromatography and purified on } \\
\qquad \mathrm{SiO}_{2} \text { plates }\end{array}$ & $\begin{array}{l}\text { Phenolic aldehydes } \\
\text { (Siphonodictyal) }\end{array}$ & $\begin{array}{c}{ }^{1} \mathrm{H} \text { and }{ }^{13} \mathrm{C} \mathrm{NMR}, \mathrm{IR}, \\
\mathrm{UV}\end{array}$ & [182] \\
\hline
\end{tabular}


Table 5. Cont.

\begin{tabular}{|c|c|c|c|c|c|c|}
\hline Scientific Name & $\begin{array}{l}\text { Phylum } \\
\text { (Class) }\end{array}$ & Collection Site & Extracting Solvent(s)/Method & $\begin{array}{l}\text { Isolated Lipids or } \\
\text { Lipid Classes }\end{array}$ & $\begin{array}{l}\text { Compound } \\
\text { Identification } \\
\text { Methods }\end{array}$ & Ref. \\
\hline $\begin{array}{l}\text { Spheciospongia } \\
\text { purpurea }\end{array}$ & $\begin{array}{c}\text { Porifera } \\
\text { (Demospongiae) }\end{array}$ & $\begin{array}{c}\text { Weizhou Island, } \\
\text { Guangxi } \\
\text { Autonomous Region, } \\
\text { China }\end{array}$ & $\begin{array}{l}\text { Acetone. Extract resuspended in } \\
\mathrm{H}_{2} \mathrm{O} \text { and partitioned with } \mathrm{Et}_{2} \mathrm{O} \text {. } \\
\mathrm{Et}_{2} \mathrm{O} \text { extract fractionated on } \mathrm{SiO}_{2} \\
\text { (petroleum ether/acetone, } 1: 0 \rightarrow 0: 1) \\
\text { Sephadex } \mathrm{LH}-20\left(\mathrm{CH}_{2} \mathrm{Cl}_{2} / \mathrm{MeOH} \text {, }\right. \\
\text { 1:1). Purification by C18 HPLC }\end{array}$ & $\begin{array}{l}\text { Lysophospholipids } \\
\text { (PAF(16:0), PAF (16:1 } \\
n-5), \text { PAF (18:0), PAF } \\
\text { (18:1 n-7), PAF (18:1 } \\
n-11), \text { PAF }(18: 1 n-13))\end{array}$ & $\begin{array}{c}{ }^{1} \mathrm{H} \text { and }{ }^{13} \mathrm{C} \text { NMR, IR, } \\
\text { ESI-MS, HR-ESI-MS, } \\
\text { LC-MS/MS }\end{array}$ & [146] \\
\hline Family Spongiidae & $\begin{array}{c}\text { Porifera } \\
\text { (Demospongiae) }\end{array}$ & $\begin{array}{c}\text { Unten Port, Okinawa, } \\
\text { Japan }\end{array}$ & $\begin{array}{l}\text { MeOH extract partitioned between } \\
\text { EtOAc and } \mathrm{H}_{2} \mathrm{O} \text {. } \mathrm{H}_{2} \mathrm{O} \text {-soluble } \\
\text { portions extracted with } n \text {-BuOH. } \\
\text { EtOAc and } n \text { - } \mathrm{BuOH} \text {, soluble } \\
\text { materials purified by } \mathrm{SiO}_{2} \text { columns } \\
\text { and } \mathrm{C} 18 \mathrm{HPLC}\end{array}$ & $\begin{array}{l}\text { Sesquiterpenoid } \\
\text { (Sesquiterpenoid } \\
\text { quinones, } \\
\text { Nakijiquinones) }\end{array}$ & $\begin{array}{l}{ }^{1} \mathrm{H} \text { and }{ }^{13} \mathrm{C} \text { NMR, } \\
\text { FAB-MS, UV, IR }\end{array}$ & [185] \\
\hline Suberites domuncula & $\begin{array}{c}\text { Porifera } \\
\text { (Demospongiae) }\end{array}$ & Rovinj, Croatia & $\begin{array}{c}\mathrm{MeOH} \text { and } \mathrm{CHCl}_{3} \text {. Combined } \\
\text { extracts partitioned between } \mathrm{H}_{2} \mathrm{O} \\
\text { and } \mathrm{BuOH} \text {. Organic layer } \\
\text { fractionated by medium-pressure on } \\
\mathrm{C} 18\left(\mathrm{linear}_{\text {gradient }} \mathrm{H}_{2} \mathrm{O} \rightarrow \mathrm{MeOH}\right. \\
\left.\rightarrow \mathrm{CHCl}_{3}\right) \text {. Purification by RP HPLC }\end{array}$ & $\begin{array}{l}\text { Lysophospholipids } \\
\text { (PAF) }\end{array}$ & $\begin{array}{c}{ }^{1} \mathrm{H} \text { NMR, FIA-MS, } \\
\text { LC-MS/MS }\end{array}$ & [157] \\
\hline Topsentia sp. & $\begin{array}{c}\text { Porifera } \\
\text { (Demospongiae) }\end{array}$ & $\begin{array}{l}\text { Chuuk, Federated } \\
\text { States of Micronesia }\end{array}$ & $\begin{array}{c}\mathrm{CH}_{2} \mathrm{Cl}_{2} / \mathrm{MeOH}(1: 1, v / v) . \text { Extract } \\
\text { fractionated by SPE using C18 } \\
\text { cartridges }\end{array}$ & $\begin{array}{l}\text { Steroid sulfates } \\
\text { (Eurysterols) }\end{array}$ & $\begin{array}{l}{ }^{1} \mathrm{H} \text { and }{ }^{13} \mathrm{C} \text { NMR, } \\
\text { HR-ESI-MS, IR, UV }\end{array}$ & [168] \\
\hline Xestospongia sp. & $\begin{array}{c}\text { Porifera } \\
\text { (Demospongiae) }\end{array}$ & $\begin{array}{c}\text { Rasch Pass of } \\
\text { Madang, Papua New } \\
\text { Guinea }\end{array}$ & $\begin{array}{l}\text { Hexane, } \mathrm{CH}_{2} \mathrm{Cl}_{2} \text { and EtOAc. } \\
\text { Hexane extract subjected to flash } \\
\text { column (gradient hexane/EtOAc } \\
\quad(95: 5, v / v) \rightarrow \text { EtOAc) }\end{array}$ & Brominated FA & $\begin{array}{c}{ }^{1} \mathrm{H} \text { and }{ }^{13} \mathrm{C} \text { NMR, IR, } \\
\text { UV, HR-EI-MS, } \\
\text { HR-APCI-MS, } \\
\text { HR-FAB-MS }\end{array}$ & [138] \\
\hline $\begin{array}{c}\text { Hyas araneus, } \\
\text { Podopthalmus vigil, } \\
\text { Lauridromia dehanni, } \\
\text { Charybdis helleri, } \\
\text { Portunus } \\
\text { sanguinolentus, } \\
\text { Portunus pelagicus }\end{array}$ & $\begin{array}{c}\text { Arthropoda } \\
\text { (Malacostraca) }\end{array}$ & Vellar Estuary, India & $\mathrm{MeOH}$ & $\begin{array}{l}\text { Lysoglycerolipids/ } \\
\text { glycerides } \\
\text { FA/esters }\end{array}$ & $\begin{array}{l}{ }^{1} \mathrm{H} \text { and }{ }^{13} \mathrm{C} \text { NMR, } \\
\text { ESI-MS/MS, FT-IR }\end{array}$ & [148] \\
\hline
\end{tabular}


Table 5. Cont.

\begin{tabular}{|c|c|c|c|c|c|c|}
\hline Scientific Name & $\begin{array}{l}\text { Phylum } \\
\text { (Class) }\end{array}$ & Collection Site & Extracting Solvent(s)/Method & $\begin{array}{l}\text { Isolated Lipids or } \\
\text { Lipid Classes }\end{array}$ & $\begin{array}{l}\text { Compound } \\
\text { Identification } \\
\text { Methods }\end{array}$ & Ref. \\
\hline $\begin{array}{c}\text { Meganyctiphanes } \\
\text { norvegica }\end{array}$ & $\begin{array}{l}\text { Arthropoda } \\
\text { (Malacostraca) }\end{array}$ & $\begin{array}{l}\text { Straits of Messina, } \\
\text { central Mediterranean } \\
\text { Sea, Italy }\end{array}$ & $\begin{array}{l}\mathrm{H}_{2} \mathrm{O} / \text { acetone }(1: 1, v / v) \text {. Supernatant } \\
\text { recovered with } \mathrm{CH}_{2} \mathrm{Cl}_{2} \text {. Extracts } \\
\text { fractionated by semi-preparative } \mathrm{RP} \\
\text { HPLC-DAD on SB-C } 8 \text { column }\end{array}$ & $\begin{array}{c}\text { FA } \\
(\mathrm{EPA}, \mathrm{DHA}, \mathrm{ETA})\end{array}$ & $\begin{array}{c}\text { LC-MS, } \\
\text { HPLC-UV-HR-MS }\end{array}$ & [141] \\
\hline Aplidium sp. & $\begin{array}{c}\text { Chordata } \\
\text { (Ascidiacea) }\end{array}$ & $\begin{array}{l}\text { Northland, New } \\
\text { Zealand }\end{array}$ & $\begin{array}{c}\mathrm{MeOH}-\mathrm{CH}_{2} \mathrm{Cl}_{2} \text { extract fractionated } \\
\text { with } \mathrm{RF} \mathrm{C} 18 \text { flash column } \\
\left(\mathrm{MeOH} / \mathrm{H}_{2} \mathrm{O}\right) \text {, Sephadex LH20 } \\
(\mathrm{MeOH}), \text { semi-preparative C18 } \\
\text { HPLC }\end{array}$ & $\begin{array}{l}\text { Meroterpene } \\
\text { derivatives } \\
\text { (Rossinones) }\end{array}$ & $\begin{array}{l}{ }^{1} \mathrm{H} \text { and }{ }^{13} \mathrm{C} \text { NMR, } \\
\text { HR-FAB-MS, UV, IR }\end{array}$ & [189] \\
\hline Eunicea succinea & $\begin{array}{l}\text { Cnidaria } \\
\text { (Anthozoa) }\end{array}$ & $\begin{array}{l}\text { Mona Island, Puerto } \\
\text { Rico, }\end{array}$ & $\begin{array}{c}\mathrm{CHCl}_{3} / \mathrm{MeOH}(1: 1, v / v) . \text { Extract } \\
\text { fractionated by } \mathrm{SiO}_{2} \text { column } \\
\text { chromatography }\end{array}$ & $\begin{array}{c}\text { FA } \\
((5 Z, 9 Z)-14 \text {-methyl- } \\
\text { 5,9-pentadecadienoic } \\
\text { acid })\end{array}$ & $\begin{array}{c}{ }^{1} \mathrm{H} \text { and }{ }^{13} \mathrm{C} \text { NMR, } \\
\text { GC-MS, HR-MS, IR }\end{array}$ & [137] \\
\hline Lobophytum crassum & $\begin{array}{l}\text { Cnidaria } \\
\text { (Anthozoa) }\end{array}$ & Rameswaram, India & $\begin{array}{l}\text { Aqueous EtOH }(95 \%), \mathrm{MeOH} \text {. } \\
\text { Extract partitioned with } \mathrm{H}_{2} \mathrm{O} \text { and } \\
\text { EtOAc. EtOAc extract fractionated } \\
\text { on } \mathrm{SiO}_{2} \text { column (gradient } \\
\text { hexane/EtOAc) }\end{array}$ & $\begin{array}{l}\text { Cembranoid } \\
\text { diterpene } \\
\text { Ceramide }\end{array}$ & $\begin{array}{c}{ }^{1} \mathrm{H} \text { and }{ }^{13} \mathrm{C} \text { NMR, } \\
\text { FAB-MS, IR }\end{array}$ & [177] \\
\hline $\begin{array}{l}\text { Antillogorgia } \\
\text { elisabethae }\end{array}$ & $\begin{array}{l}\text { Cnidaria } \\
\text { (Anthozoa) }\end{array}$ & Bahamas & $\begin{array}{c}\mathrm{MeOH} \text {. Extract redissolved in } \\
\text { EtOH/ } \mathrm{H}_{2} \mathrm{O}(2: 8, v / v) . \text { EtOH/ } \mathrm{H}_{2} \mathrm{O} \\
\text { extract reextracted with EtOAc, } \mathrm{SiO}_{2} \\
\text { column (hexane, } 0 \rightarrow 100 \% \\
\text { EtOAc/hexane, } 0 \rightarrow 100 \% \\
\mathrm{MeOH} / \mathrm{EtOAc}) \text {. Fractions subjected } \\
\text { to } \mathrm{RP} \text { HPLC }(0 \rightarrow 100 \% \\
\mathrm{H}_{2} \mathrm{O} / \text { Acetonitrile) }\end{array}$ & $\begin{array}{l}\text { Diterpenes } \\
\text { (Elisabethin) }\end{array}$ & $\begin{array}{c}{ }^{1} \mathrm{H},{ }^{13} \mathrm{C} \text { NMR, } \\
\text { HR-EI-MS, UV, IR }\end{array}$ & [192] \\
\hline $\begin{array}{l}\text { Sinularia grandilobata, } \\
\text { Sinularia sp. }\end{array}$ & $\begin{array}{l}\text { Cnidaria } \\
\text { (Anthozoa) }\end{array}$ & $\begin{array}{l}\text { Andaman Islands, } \\
\text { India }\end{array}$ & $\begin{array}{l}\text { EtOH. Extract reextracted with } \\
\text { EtOAc. Combined extracts } \\
\text { fractionated on } \mathrm{SiO}_{2} \text { column } \\
\text { (gradient system hexane/EtOAc } \\
\qquad(100: 0 \rightarrow 0: 100))\end{array}$ & $\begin{array}{l}\text { Sphingolipids } \\
\text { Glycolipids }\end{array}$ & $\begin{array}{c}{ }^{1} \mathrm{H} \text { and }{ }^{13} \mathrm{C} \text { NMR, } \\
\text { EI-MS }\end{array}$ & [139] \\
\hline
\end{tabular}


Table 5. Cont.

\begin{tabular}{|c|c|c|c|c|c|c|}
\hline Scientific Name & $\begin{array}{l}\text { Phylum } \\
\text { (Class) }\end{array}$ & Collection Site & Extracting Solvent(s)/Method & $\begin{array}{l}\text { Isolated Lipids or } \\
\text { Lipid Classes }\end{array}$ & $\begin{array}{l}\text { Compound } \\
\text { Identification } \\
\text { Methods }\end{array}$ & Ref. \\
\hline Holothuria scabra & $\begin{array}{l}\text { Echinodermata } \\
\text { (Echinozoa) }\end{array}$ & Red Sea, Egypt & $\begin{array}{c}\mathrm{EtOH}(70 \%), \mathrm{MeOH}, \mathrm{EtOAc} \text { and } \\
\mathrm{CHCl}_{3} / \mathrm{MeOH}(2: 1, v / v)\end{array}$ & $\begin{array}{c}\text { Pigments } \\
\text { (Carotenoids) }\end{array}$ & $\begin{array}{l}\text { HPLC-UV/VIS, } \\
\text { GC-MS }\end{array}$ & [193] \\
\hline Dosidicus gigas & $\begin{array}{c}\text { Mollusca } \\
\text { (Cephalopoda) }\end{array}$ & Hermosillo, Mexico & $\begin{array}{c}\text { Acidified } \mathrm{MeOH}(\mathrm{MeOH} / \mathrm{HCl}, 99: 1, \\
v / v)\end{array}$ & $\begin{array}{c}\text { Pigments } \\
\text { (Ommochrome) } \\
\end{array}$ & $\begin{array}{c}{ }^{1} \mathrm{H} \text { and }{ }^{13} \mathrm{C} \text { NMR, } \\
\text { FT-IR, }\end{array}$ & [144] \\
\hline Saccostrea glomerata & $\begin{array}{l}\text { Mollusca } \\
\text { (Bivalvia) }\end{array}$ & $\begin{array}{l}\text { Kovalam, Tamilnadu, } \\
\text { India }\end{array}$ & $\begin{array}{c}\text { Hexane, EtOAc and MeOH. } \\
\text { Purification on } \mathrm{SiO}_{2} \text { column } \\
\text { (hexane/EtOAc and EtOAc/MeOH) }\end{array}$ & $\begin{array}{c}\text { Sterols } \\
\text { [Cholesta-5,22-dien- } \\
3 \beta \text {-ol, Cholesterol, } \\
\text { Ergosta-5,22-dien-3-ol, } \\
(3 \beta, 22 \mathrm{E}) \text {-] } \\
\text { FA (6-Octadecenoic } \\
\text { acid, Octadecanoic } \\
\text { acid) }\end{array}$ & GC-MS, FT-IR & [171] \\
\hline
\end{tabular}


Table 6. Antimicrobial activity of lipids or lipid-rich extracts from marine invertebrates.

\begin{tabular}{|c|c|c|c|c|c|c|}
\hline Scientific Name & Activity & Tested (Micro)Organisms & $\begin{array}{c}\text { Antimicrobial } \\
\text { Testing } \\
\text { Method/Evaluation }\end{array}$ & $\begin{array}{c}\text { Reference } \\
\text { Antimicrobial } \\
\text { (Positive Control) }\end{array}$ & $\begin{array}{l}\text { MIC, Diameter of } \\
\text { Inhibition Zone (IZ) } \\
\text { or Other }\end{array}$ & Ref. \\
\hline \multirow[b]{2}{*}{ Acanthodendrilla sp. } & Antifungal & $\begin{array}{c}\text { Yeast: S. cerevisiae (A364A, } \\
\text { STX338-2C, 14028g, } \\
\text { GT160-45C) }\end{array}$ & $\begin{array}{l}\text { Disk diffusion } \\
\text { method }\end{array}$ & & IZ (mm): 7-11 & [169] \\
\hline & $\begin{array}{l}\text { Antibacterial } \\
\text { Antifungal }\end{array}$ & $\begin{array}{c}\text { G(+): S. aureus, B. subtilis } \\
\text { G(-): E. coli, } \\
\text { Yeast: C. albicans } \\
\text { Fungi: Cladosporium herbarum }\end{array}$ & $\begin{array}{l}\text { Disk diffusion } \\
\text { method }\end{array}$ & & $\begin{array}{l}\text { IZ }(\mathrm{mm}) \\
\text { S. aureus: } 7-11 \\
\text { B. subtilis: } 7-12 \\
\text { E. coli: } 7-12 \\
\text { C. albicans: } 9-10 \\
\text { C. herbarum: } 10-20\end{array}$ & [190] \\
\hline Agelas oroides & $\begin{array}{l}\text { Antibacterial, } \\
\text { Antiplasmodial }\end{array}$ & $\begin{array}{c}\text { Acid-fast bacterium: } M . \\
\text { tuberculosis } \\
\text { Parasitic protozoa: } P . \\
\text { falciparum, } \\
\text { Trypanosoma brucei rhodesiense, } \\
\text { T. cruzi, L. donovani } \\
\text { G(-): E. coli }\end{array}$ & $\begin{array}{l}{\left[{ }^{3} \mathrm{H}\right] \text {-hypoxanthine }} \\
\text { incorporation assay, } \\
\text { 96-well microtiter } \\
\text { plates, inhibition of } \\
\text { enzymatic activity }\end{array}$ & $\begin{array}{l}\text { Artemisinin, } \\
\text { Benznidazole, } \\
\text { Melarsoprol, } \\
\text { Miltefosine, } \\
\text { Podophyllotoxin, } \\
\text { Triclosan }\end{array}$ & $\begin{array}{c}\mathrm{IC}_{50}(\mu \mathrm{g} / \mathrm{mL}) \\
\text { Antibacterial } \\
\text { M. tuberculosis: } \\
\quad 9.4->50 \\
\text { E. coli: } 0.07->50 \\
\text { Antiprotozoal: } \\
\quad 0.35->30\end{array}$ & [162] \\
\hline \multirow[b]{2}{*}{ Caminus sphaeroconia } & Antibacterial & $\begin{array}{c}\mathrm{G}(+) \text { : MRSA, Enterococcus } \\
\text { (VRE) } \\
\text { G(-): E. coli }\end{array}$ & in vitro inhibition & & $\begin{array}{l}\text { MIC }(\mu \mathrm{g} / \mathrm{mL}) \\
\text { MRSA: } 12 \\
\text { VRE: } 12 \\
\text { E. coli: }>100\end{array}$ & [147] \\
\hline & Antibacterial & $\begin{array}{c}\text { G(+): MRSA, Enterococcus } \\
\text { (VRE) } \\
\text { G(-): Xanthomonas maltophilia } \\
\text { Plant pathogen: Pythium } \\
\text { ultimum }\end{array}$ & $\begin{array}{l}\text { Disk diffusion } \\
\text { method }\end{array}$ & & $\begin{array}{c}\text { MIC }(\mu \mathrm{g} / \text { disk }) \\
\text { MRSA: } 6.3->100 \\
\text { VRE: } 3.1->100 \\
\text { X. maltophilia: } \\
\text { 25->100 } \\
\text { P. ultimum: } 25->100\end{array}$ & [176] \\
\hline Dysidea arenaria & Antiviral & Virus: HIV-1 & & PFA & $\mathrm{IC}_{50}(\mu \mathrm{M}) 16.4-239.7$ & {$[184]$} \\
\hline
\end{tabular}


Table 6. Cont

\begin{tabular}{|c|c|c|c|c|c|c|}
\hline Scientific Name & Activity & Tested (Micro)Organisms & $\begin{array}{c}\text { Antimicrobial } \\
\text { Testing } \\
\text { Method/Evaluation }\end{array}$ & $\begin{array}{c}\text { Reference } \\
\text { Antimicrobial } \\
\text { (Positive Control) }\end{array}$ & $\begin{array}{l}\text { MIC, Diameter of } \\
\text { Inhibition Zone (IZ) } \\
\text { or Other }\end{array}$ & Ref. \\
\hline Dysidea sp. & Antibacterial & $\begin{array}{c}\mathrm{G}(+) \text { : S. aureus, B. subtilis, } \\
\text { M. luteus } \\
\text { G(-): P. vulgaris, } \\
\text { S. typhimurium, E. coli }\end{array}$ & $\begin{array}{l}\text { Broth macrodilution } \\
\text { method }\end{array}$ & Linezolid & $\begin{array}{c}\mathrm{MIC}(\mu \mathrm{g} / \mathrm{mL}) \\
0.117->15\end{array}$ & {$[183]$} \\
\hline Erylus lendenfeldi & Antifungal & Yeast: C. albicans & & & $\operatorname{MIC}(\mu \mathrm{g} / \mathrm{mL}) 15.6$ & {$[172]$} \\
\hline Erylus placenta & Antifungal & $\begin{array}{c}\mathrm{G}(+): \text { S. aureus } \\
\mathrm{G}(-): \text { E. coli } \\
\text { Fungus: Mortierella } \\
\text { ramanniana } \\
\text { Yeasts: S. cerevisiae (cdc28, } \\
\text { act1-1, erg6) }\end{array}$ & $\begin{array}{l}\text { Disk diffusion } \\
\text { method }\end{array}$ & & $\begin{array}{l}\mathrm{IZ}(\mathrm{mm}) \\
\text { M. ramanniana: } 11-12 \\
\text { S. cerevisiae: } 8-18\end{array}$ & {$[174]$} \\
\hline Euryspongia sp. & Antifungal & $\begin{array}{l}\text { Yeasts: C. albicans (ATCC } \\
\text { 32354, wild-type) (ATCC } \\
\text { 90873, amphotericin } \\
\text { B-resistant) }\end{array}$ & $\begin{array}{l}\text { Liquid antifungal } \\
\text { assay }\end{array}$ & Amphotericin B & $\begin{array}{c}\mathrm{MIC}(\mu \mathrm{g} / \mathrm{mL}): \\
15.6-62.5\end{array}$ & {$[167]$} \\
\hline
\end{tabular}


Table 6. Cont

\begin{tabular}{|c|c|c|c|c|c|c|}
\hline Scientific Name & Activity & Tested (Micro)Organisms & $\begin{array}{c}\text { Antimicrobial } \\
\text { Testing } \\
\text { Method/Evaluation }\end{array}$ & $\begin{array}{c}\text { Reference } \\
\text { Antimicrobial } \\
\text { (Positive Control) }\end{array}$ & $\begin{array}{l}\text { MIC, Diameter of } \\
\text { Inhibition Zone (IZ) } \\
\text { or Other }\end{array}$ & Ref. \\
\hline \multirow[t]{2}{*}{ Halichondria sp. } & $\begin{array}{l}\text { Antibacterial } \\
\text { Antifungal }\end{array}$ & $\begin{array}{c}\mathrm{G}(+): \text { M. luteus, B. subtilis } \\
\text { G(-): } \\
\text { E. coli } \\
\text { Yeasts: C. neoformans, } \\
\text { C. albicans, } \\
\text { Fungi: Paecilomyces variotii, A. } \\
\text { niger, A. fumigatus }\end{array}$ & $\begin{array}{l}\text { Broth microdilution } \\
\text { method }\end{array}$ & & $\begin{array}{c}\text { MIC }(\mu \mathrm{g} / \mathrm{mL}) \\
\text { M. luteus: } 0.52 \\
\text { C. neoformans: } 0.0625 \\
\text { C. albicans: } 2.09 \\
\text { P. variotii: } 1.04 \\
\text { A. niger: } 1.04 \\
\text { A. fumigatus: } 1.04\end{array}$ & {$[187]$} \\
\hline & $\begin{array}{l}\text { Antibacterial } \\
\text { Antifungal }\end{array}$ & $\begin{array}{c}\mathrm{G}(+): \text { M. luteus } \\
\text { Yeast: C. neoformans } \\
\text { Fungi: T. mentagrophytes }\end{array}$ & & & $\begin{array}{c}\text { MIC }(\mu \mathrm{g} / \mathrm{mL}) \\
\text { M. luteus: } 4 \\
\text { T. mentagrophytes: } \\
\quad 8-16 \\
\text { C. neoformans: } 16\end{array}$ & {$[188]$} \\
\hline Haliclona simulans & $\begin{array}{l}\text { Anti-mycobacterial } \\
\text { Antitrypanosomal }\end{array}$ & $\begin{array}{c}\text { Acid-fast bacterium: } \\
\text { Mycobacterium marinum } \\
\text { Parasitic trypanosomatida: } T \text {. } \\
\text { brucei }\end{array}$ & $\begin{array}{l}\text { Broth microdilution } \\
\text { method }\end{array}$ & Gentamycin & $\begin{array}{c}\operatorname{MIC}(\mu \mathrm{M}): M . \\
\text { marinum: } 156.9-288.8 \\
\text { T. b. brucei: } 4.58-21.56\end{array}$ & {$[170]$} \\
\hline Jaspis stellifera & $\begin{array}{c}\text { Antibacterial } \\
\text { Antifungal }\end{array}$ & $\begin{array}{c}\mathrm{G}(+) \text { : Sarcina lutea } \\
\text { Yeast: C. neoformans } \\
\text { Fungi: T. mentagrophytes }\end{array}$ & & & $\begin{array}{c}\text { MIC }(\mu \mathrm{g} / \mathrm{mL}) \\
\text { S. lutea: } 50 \\
\text { C. neoformans: } 50 \\
\text { T. mentagrophytes: } 12.5\end{array}$ & {$[181]$} \\
\hline Luffariella geometrica & Antibacterial & $\begin{array}{c}\mathrm{G}(+) \text { : S. aureus, Micrococcus } \\
\text { sp. } \\
\text { Yeast: } \text { S. cerevisiae }\end{array}$ & $\begin{array}{l}\text { Disk diffusion } \\
\text { method }\end{array}$ & & $\begin{array}{c}\text { EC }(\mu \mathrm{g} / \text { disk }) \\
\text { S. aureus: } 100 \\
\text { Micrococcus sp.: } 100\end{array}$ & {$[178]$} \\
\hline \multirow[b]{2}{*}{ Luffariella variabilis } & Antibacterial & $\begin{array}{c}\mathrm{G}(+) \text { : Streptomyces pyogenes, } \\
\text { S. aureus }\end{array}$ & & & $\begin{array}{l}\text { Active against } S . \\
\text { pyogenes, } S . \text { aureus }\end{array}$ & {$[180]$} \\
\hline & Antibacterial & $\begin{array}{l}\mathrm{G}(+) \text { : S. aureus, B. subtilis } \\
\mathrm{G}(-) \text { : E. coli, P. aeruginosa } \\
\text { Yeast: C. albicans }\end{array}$ & & & $\begin{array}{l}\text { Active against } S \text {. } \\
\text { aureus, } B \text {. subtilis }\end{array}$ & {$[179]$} \\
\hline
\end{tabular}


Table 6. Cont

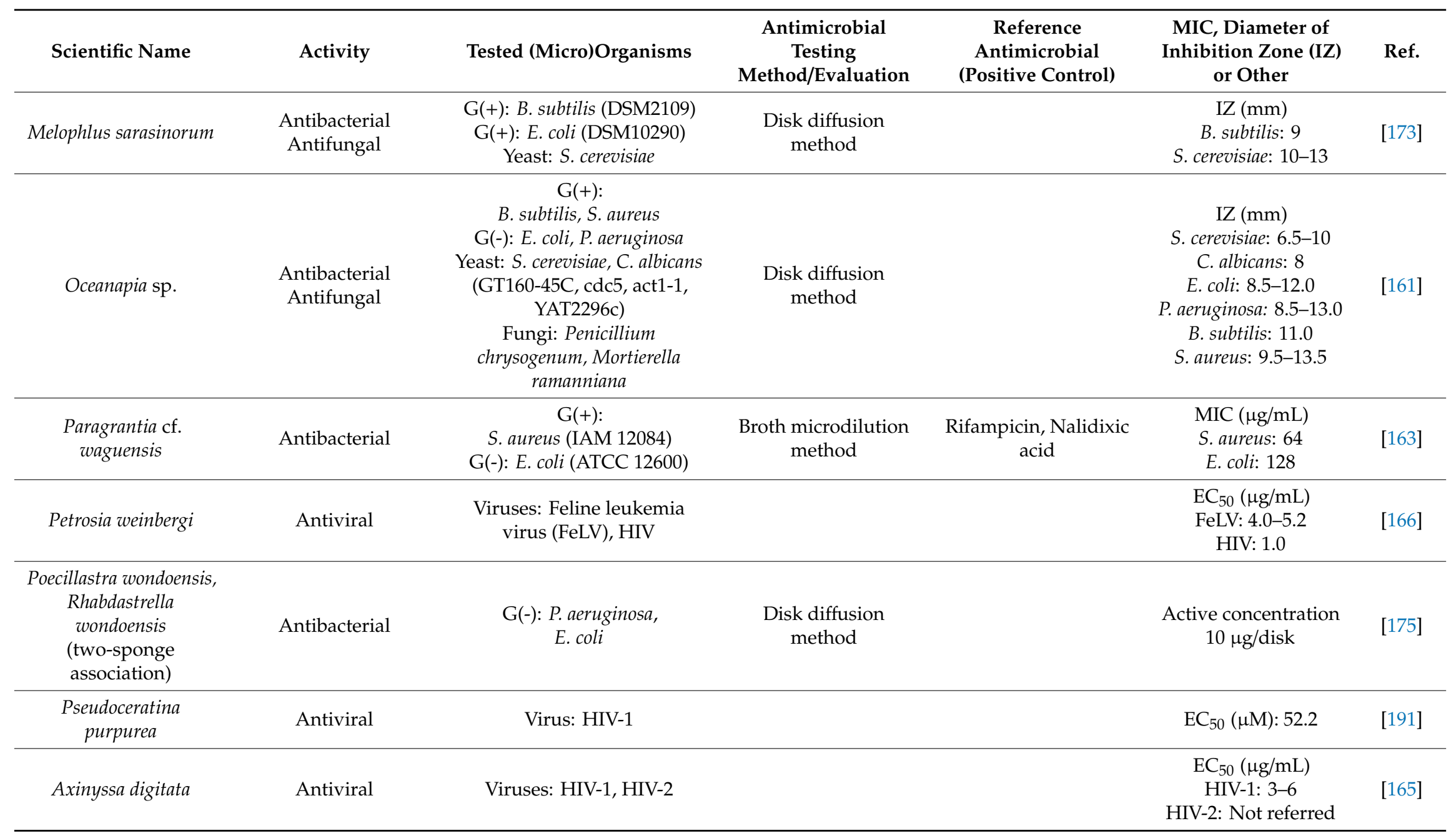


Table 6. Cont

\begin{tabular}{|c|c|c|c|c|c|c|}
\hline Scientific Name & Activity & Tested (Micro)Organisms & $\begin{array}{c}\text { Antimicrobial } \\
\text { Testing } \\
\text { Method/Evaluation }\end{array}$ & $\begin{array}{c}\text { Reference } \\
\text { Antimicrobial } \\
\text { (Positive Control) }\end{array}$ & $\begin{array}{l}\text { MIC, Diameter of } \\
\text { Inhibition Zone (IZ) } \\
\text { or Other }\end{array}$ & Ref. \\
\hline Siliquariaspongia sp. & Antibacterial & $\begin{array}{c}\mathrm{G}(+): \\
\text { S. aureus, MRSA }\end{array}$ & $\begin{array}{l}\text { Disk diffusion } \\
\text { method, Microbroth } \\
\text { dilution }\end{array}$ & & $\begin{array}{c}\mathrm{MIC}_{50}(\mu \mathrm{g} / \mathrm{mL}) \\
\text { S. aureus: } 1.2-10.9 \\
\text { S. aureus }(\mathrm{MRSA}) \text { : } \\
\quad 3.9-400\end{array}$ & [164] \\
\hline $\begin{array}{l}\text { Siphonodictyon } \\
\text { coralliphagum }\end{array}$ & Antibacterial & $\begin{array}{l}\mathrm{G}(+) \text { : S. aureus, } \\
\text { B. subtilis }\end{array}$ & & & $\begin{array}{l}\text { Active against } S \text {. } \\
\text { aureus, B. subtilis }\end{array}$ & [182] \\
\hline $\begin{array}{c}\text { Spheciospongia } \\
\text { purpurea }\end{array}$ & Antifungal & $\begin{array}{c}\text { Yeasts: C. neoformans (32609), } \\
\text { C. glabrata (537) } \\
\text { Fungi: T. rubrum (Cmccftla), } \\
\text { A. fumigatus (07544), }\end{array}$ & Broth dilution & $\begin{array}{l}\text { Amphotericin B, } \\
\text { Fluconazole, } \\
\text { Voriconazole, } \\
\text { Ketoconazole }\end{array}$ & $\begin{array}{l}\mathrm{MIC}_{80}(\mu \mathrm{g} / \mathrm{mL}) \\
\text { C. neoformans: } 4-32 \\
\text { C. glabrata: } 8-64 \\
\text { A. fumigatus: }>64 \\
\text { T. rubrum: }>64\end{array}$ & [146] \\
\hline Family Spongiidae & $\begin{array}{c}\text { Antibacterial } \\
\text { Antifungal }\end{array}$ & $\begin{array}{c}\mathrm{G}(+) \text { : B. subtilis, } \text { M. luteus, } S \text {. } \\
\text { aureus } \\
\text { G(-): E. coli } \\
\text { Yeasts: C. albicans, C. } \\
\text { neoformans } \\
\text { Fungi: } \text { A. niger }\end{array}$ & & & $\begin{array}{c}\text { MIC }(\mu \mathrm{m} / \mathrm{mL}) \\
\text { B. subtilis: } 33.3 \\
\text { E. coli: }>33.3 \\
\text { M. luteus: } 16.7-33.3 \\
\text { S. aureus: } 33.3 \\
\text { C. neoformans: } 8.35 \\
\text { C. albicans: } 8.35 \\
\text { A. niger: } 16.7\end{array}$ & [185] \\
\hline Suberites domuncula & Antibacterial & $\begin{array}{c}\text { Bacterium SB1 (strain } \\
\text { isolated from S. domuncula } \\
\text { with }>98.0 \% \text { similarity to the } \\
\text { alpha-Proteobacterium } \\
\text { (MBIC3368) }\end{array}$ & $\begin{array}{l}\text { Disk diffusion } \\
\text { method }\end{array}$ & & IZ (mm): 4.5-6.8 & [157] \\
\hline
\end{tabular}


Table 6. Cont

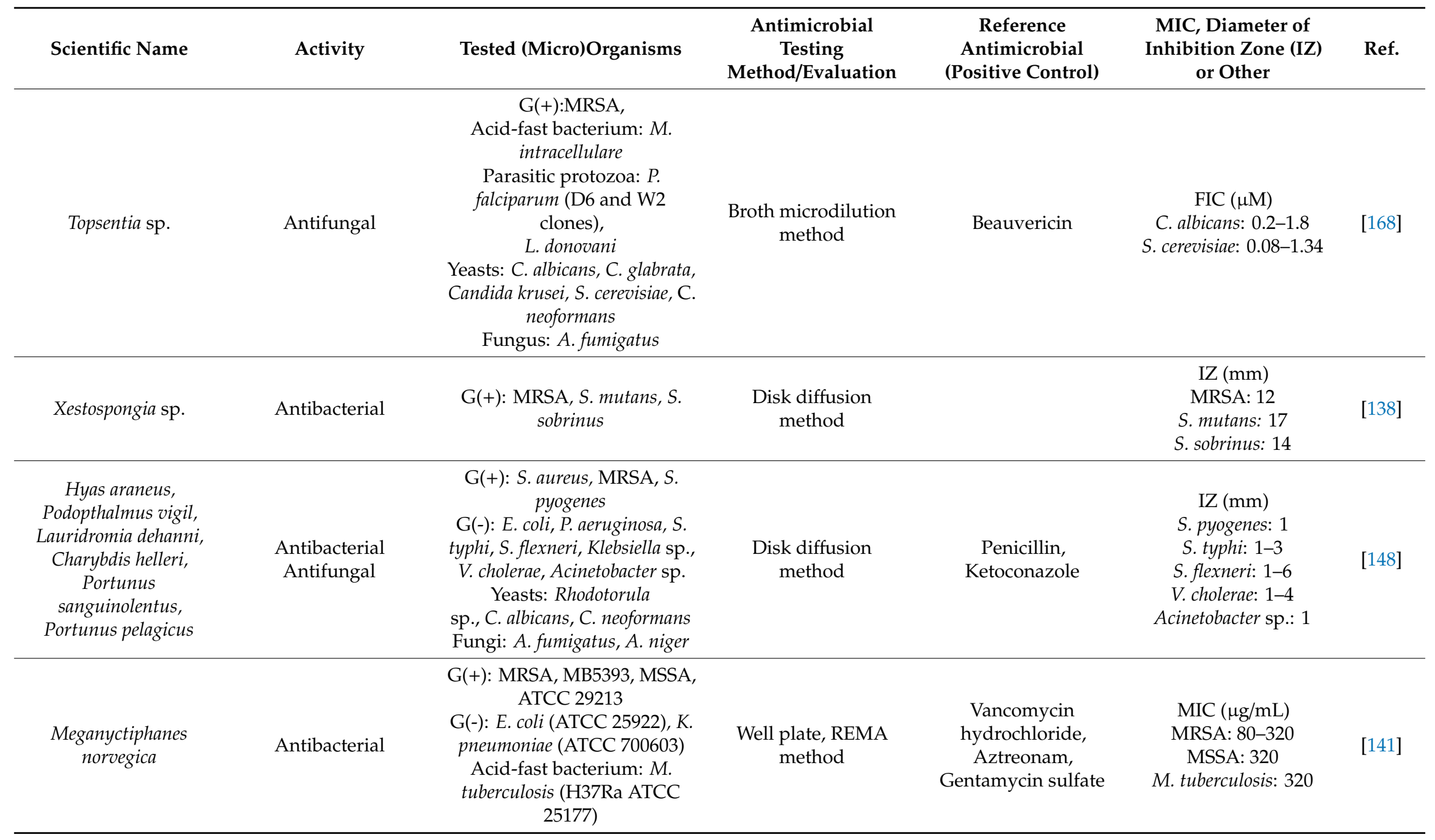


Table 6. Cont

\begin{tabular}{|c|c|c|c|c|c|c|}
\hline Scientific Name & Activity & Tested (Micro)Organisms & $\begin{array}{c}\text { Antimicrobial } \\
\text { Testing } \\
\text { Method/Evaluation }\end{array}$ & $\begin{array}{c}\text { Reference } \\
\text { Antimicrobial } \\
\text { (Positive Control) }\end{array}$ & $\begin{array}{l}\text { MIC, Diameter of } \\
\text { Inhibition Zone (IZ) } \\
\text { or Other }\end{array}$ & Ref. \\
\hline Aplidium sp. & $\begin{array}{l}\text { Antibacterial } \\
\text { Antiviral } \\
\text { Antifungal }\end{array}$ & $\begin{array}{c}\mathrm{G}(+): \text { B. subtilis } \\
\text { Fungi: T. mentagrophytes } \\
\text { Virus: HSV-1 }\end{array}$ & $\begin{array}{l}\text { Disk diffusion } \\
\text { method }\end{array}$ & & $\begin{array}{c}\mathrm{IZ}(\mathrm{mm}) \\
\text { B. subtilis/T. } \\
\text { mentagrophytes: } 3-6 \\
\text { Antiviral activity at } 2 \\
\mu \mathrm{g} / \text { disk }\end{array}$ & [189] \\
\hline Eunicea succinea & Antibacterial & $\begin{array}{c}\text { G(+): S. aureus (ATCC 25923), } \\
\text { E. faecalis (ATCC 29212) } \\
\text { G(-): P. aeruginosa (ATCC } \\
\text { 27853), E. coli (ATCC 25922) }\end{array}$ & $\begin{array}{l}\text { Broth microdilution } \\
\text { method }\end{array}$ & & $\begin{array}{c}\text { MIC }(\mu \mathrm{mol} / \mathrm{mL}) / \mathrm{IC}_{50} \\
(\mu \mathrm{g} / \mathrm{mL}) \\
\text { S. aureus: } 0.24 / 36 \\
\text { E. faecalis: } 0.16 /<10\end{array}$ & [137] \\
\hline Lobophytum crassum & Antibacterial & $\begin{array}{c}\mathrm{G}(+) \text { : S. epidermidis, B. subtilis, } \\
\text { S. aureus } \\
\text { G(-): P. aeruginosa }\end{array}$ & $\begin{array}{l}\text { Disk diffusion } \\
\text { method }\end{array}$ & Ampicillin & $\begin{array}{l}\text { IZ (mm) } \\
\text { S. epidermidis: } 9.5-16.5 \\
\text { B. subtilis: } 8.5-18.0 \\
\text { S. aureus: } 9.0-19.5 \\
\text { P. aeruginosa: } 9.0-14.0\end{array}$ & [177] \\
\hline $\begin{array}{c}\text { Antillogorgia } \\
\text { elisabethae }\end{array}$ & Antibacterial & $\begin{array}{c}\text { G(+): S. pyogenes (ATCC } \\
\text { 19615), S. aureus (ATCC } \\
\text { 25923), E. faecalis (ATCC } \\
\text { 19433) } \\
\text { G(-): E. coli (ATCC 25933), P. } \\
\text { aeruginosa (ATCC 27853) }\end{array}$ & $\begin{array}{l}\text { Disk diffusion } \\
\text { method }\end{array}$ & & $\begin{array}{c}\text { MIC }(\mu \mathrm{g} / \mathrm{mL}) / \mathrm{IZ}(\mathrm{mm}) \\
\text { S. pyogenes: } \\
0.8-1.0 / 12-17 \\
\text { S. aureus: } 2.0-2.3 / 8-11 \\
\text { E. faecalis: } 3.2-3.8 / 8-9\end{array}$ & [192] \\
\hline $\begin{array}{l}\text { Sinularia grandilobata, } \\
\text { Sinularia sp. }\end{array}$ & $\begin{array}{c}\text { Antibacterial } \\
\text { Antifungal }\end{array}$ & $\begin{array}{c}\text { G(+): B. subtilis (MTCC 441), } \\
\text { Bacillus pumilus (NCIM 2327) } \\
\text { G(-): E. coli } \\
\text { (MTCC 443), P. aeruginosa } \\
\text { (MTCC 1688) } \\
\text { Yeast: C. albicans (MTCC 183) } \\
\text { Fungi: A. niger (MTCC 1344), } \\
\text { Rhizopus oryzae (MTCC 1987) }\end{array}$ & $\begin{array}{l}\text { Disk diffusion } \\
\text { method }\end{array}$ & & $\begin{array}{l}\text { IZ }(\mathrm{mm}) \\
\text { B. subtilis: } 11-18 \\
\text { B. pumilus: } 11-16 \\
\text { E. coli: } 11-17 \\
\text { P. aeruginosa: } 11-17 \\
\text { C. albicans: } 8-17 \\
\text { A. niger: } 10-16 \\
\text { R. oryzae: } 10-15\end{array}$ & [139] \\
\hline
\end{tabular}


Table 6. Cont.

\begin{tabular}{|c|c|c|c|c|c|c|}
\hline Scientific Name & Activity & Tested (Micro)Organisms & $\begin{array}{c}\text { Antimicrobial } \\
\text { Testing } \\
\text { Method/Evaluation } \\
\end{array}$ & $\begin{array}{c}\text { Reference } \\
\text { Antimicrobial } \\
\text { (Positive Control) }\end{array}$ & $\begin{array}{l}\text { MIC, Diameter of } \\
\text { Inhibition Zone (IZ) } \\
\text { or Other }\end{array}$ & Ref. \\
\hline Holothuria scabra & Antibacterial & $\begin{array}{c}\text { G(+): S. aureus (ATCC 6538), } \\
\text { E. faecalis } \\
\text { G(-): P. aeruginosa (ATCC } \\
\text { 8739), V. damsela, E. coli }\end{array}$ & $\begin{array}{l}\text { Well-cut diffusion } \\
\text { technique }\end{array}$ & & $\begin{array}{c}\text { AU } \\
\text { S. aureus: } 1.2-2.8 \\
\text { E. faecalis: } 1.7-3.2 \\
\text { P. aeruginosa: } 1.4-1.8 \\
\text { V. damsela: } 1.6 \\
\text { E. coli: } 1.2\end{array}$ & [193] \\
\hline
\end{tabular}


Table 6. Cont.

\begin{tabular}{|c|c|c|c|c|c|c|}
\hline Scientific Name & Activity & Tested (Micro)Organisms & $\begin{array}{c}\text { Antimicrobial } \\
\text { Testing } \\
\text { Method/Evaluation }\end{array}$ & $\begin{array}{c}\text { Reference } \\
\text { Antimicrobial } \\
\text { (Positive Control) }\end{array}$ & $\begin{array}{l}\text { MIC, Diameter of } \\
\text { Inhibition Zone (IZ) } \\
\text { or Other }\end{array}$ & Ref. \\
\hline Saccostrea glomerata & $\begin{array}{c}\text { Antibacterial } \\
\text { Antifungal }\end{array}$ & $\begin{array}{c}\mathrm{G}(+) \text { : S. aureus } \\
\mathrm{G}(-) \text { : P. aeruginosa, V. harveyi, } \\
\text { A. hydrophila, P. aeruginosa, V. } \\
\text { harveyi, V. parahaemolyticus } \\
\text { Yeast: C. albicans } \\
\text { Fungi: A. niger, A. flavus, } \\
\text { Fusarium sp. } \\
\text { Virus: White spot syndrome } \\
\text { virus (WSSV) }\end{array}$ & $\begin{array}{l}\text { Disk diffusion } \\
\text { method }\end{array}$ & & $\begin{array}{c}\text { IZ (mm) } \\
\text { P. aeruginosa: } 4.1-16.0 \\
\text { V. harveyi: } 3.8-14.9 \\
\text { A. hydrophila: } 5.1-14.5 \\
\text { A. niger: No } \\
\text { activity-High activity } \\
\text { C. albicans: No } \\
\text { activity-High activity } \\
\text { Fusarium sp: No } \\
\text { activity-High activity } \\
\text { Antiviral activity: PI } \\
<91.85 \%\end{array}$ & [171] \\
\hline
\end{tabular}

Abbreviations: AU: activity unit for the clear zone; EC: effective concentration; FIC: fractional inhibitory concentration; IZ: inhibition zone; MIC: minimum inhibitory concentration;

PI: percentage inhibition. 


\subsubsection{Sterols}

Sterols with singular structures were isolated from marine invertebrates, exhibiting novel carbon skeletons. Marine sponges were found to be sources of steroid sulfates with antiviral activity against HIV [165,166] and against feline leukemia virus (FeLV) [166] and antifungal activity against the yeasts C. albicans $[167,168]$ and S. cerevisiae $[168,169]$. Three sterols were isolated and identified in the marine sponge Haliclona simulans with anti-mycobacterial and anti-trypanosomal activity [170]. The EtOAc extract of the flesh of the rock oyster Saccostrea glomerate was fractionated, and the best active fraction showed several sterols (e.g., cholesterol, stigmasterol, sitosterol) and FA as putative active compounds with antibacterial and antifungal activities against a broad spectrum of microorganisms [171]. Steroidal glycosides (e.g., eryloside, wondosterols, sarasinoside, sokodosides) isolated from marine sponges also showed antimicrobial properties [172-175].

\subsubsection{Polar Lipids}

Polar lipids are the main constituents of biological membranes and are also present in biofluids. The methanolic extracts of both the hemolymph (plasma) and hemocytes (plasma cells) of six brachyuran crabs revealed antimicrobial activity against sixteen bacterial and fungal pathogenic strains [148]. The antimicrobial activity of the hemolymph extracts was assigned to the presence of polar lipids [148].

A new family of antimicrobial glycolipids, caminosides, isolated from the marine sponge Caminus sphaeroconia showed a potent in vitro inhibition against a panel of human and plant pathogens (e.g., MRSA, vancomycin-resistant Enterococcus) and enteropathogenic E. coli (EPEC) $[147,176]$. Several ceramide and glycolipid molecular species have been isolated from soft corals of the genus Sinularia, and exhibited antibacterial and antifungal activity against seven microbial strains [139]. A ceramide from the cnidaria Lobophytum crassum showed moderate antibacterial activity against P. aeruginosa, S. epidermis, B. subtilis, and S. aureus [177].

Six lysophospholipids (lyso-platelet-activating factor, PAF) isolated from the sponge Spheciospongia purpurea displayed moderate antifungal activity against C. neoformans, C. glabrata, T. rubrum, and A. fumigatus [146]. The lyso-PAF molecular species were identified as PAF(16:0), PAF (16:1 n-5), PAF (18:0), PAF (18:1 $n$-7), PAF (18:1 $n$-11), and PAF (18:1 n-13) [146]. Two lyso-PAF, 1-O-hexadecylsn-glycero-3-phosphocholine and 1-O-octa-decyl-sn-glycero-3-phosphocholine, from the demosponge Suberites domuncula were separated and purified by reverse-phase (RP) HPLC, with further characterization by FIA-MS, LC-MS, and ESI-MS [157]. These compounds demonstrated a potent antibacterial activity against the bacterium SB1, isolated from $S$. domuncula, which presented a high species-level similarity ( $>98 \%$ ) to the $\alpha$-Proteobacterium MBIC3368 [157].

\subsubsection{Other Lipids}

Diverse structural modifications of isoprene units provide terpenes with a large range of biological activities [34]. These compounds were isolated mainly from Demospongiae species [178-182] and displayed antimicrobial activity against several infectious agents [183-186]. Six sesquiterpenoids, termed halichonadins, isolated from the marine sponge Halichondria sp. showed antimicrobial activity against the bacterium $M$. luteus, the yeast $C$. neoformans, and the mold Trichophyton mentagrophytes $[187,188]$. A cembranoid diterpene isolated from the cnidaria L. crassum showed strong antibacterial activity against P. aeruginosa, S. epidermis, B. subtilis, and S. aureus [177]. Two meroterpenoids, rossinones, from the Antarctic ascidian Aplidium sp. exhibited antiviral, antibacterial, and antifungal activities [189].

Terpenes with functional activities were identified in the cnidaria phylum, as from the soft coral Antillogorgia elisabethae [192]. Seven diterpenes showed potent antibacterial activity against the Gram-positive bacteria S. pyogenes, S. aureus, and E. faecalis [192]. A new series of lipids, termed mololipids, were found in the lipidome of a sponge from the order Verongida (recognized as "the Moloka'i sponge") and were reported to be active against HIV-1 [191]. These lipids present a core 
moloka'iamine nucleus with two FA-derived side chains, saturated linear and iso-methyl branched ranging from 14 to 20 carbons [191].

\subsubsection{Pigments}

Xanthophyll, $\beta$-cryptoxanthin, and $\beta$-carotene obtained from the flesh and coelomic fluid of Holothuria scabra (sea cucumbers) showed antibacterial activity against S. aureus [193]. Skin pigments of the jumbo squid Dosidicus gigas exhibited growth inhibition against several bacteria, fungi, and yeast species [144]. The highest inhibition zone diameter was verified against S. enterica, and ommatins, specifically of the xanthommatin type, were suggested as the main active compounds [144].

\section{Cytotoxicity of Natural Antimicrobial Lipids against Mammalian Cells}

Some lipid and lipid-rich extracts from natural sources showed high MIC and MBC values, in the range of $\mathrm{mg} / \mathrm{mL}$, as can be seen in Table 2, Table 4, and Table 6. This is more than one thousand times larger than is of pharmaceutical significance and raises an important question regarding cytotoxicity to mammalian cells and safety to human beings. Some studies emphasized the low toxicity to eukaryotic cells of antimicrobial lipids from natural sources, namely of FA [158]. But most studies that searched for natural lipids with antimicrobial activity did not perform in vitro or in vivo cytotoxicity experiments. Data regarding mammalian cytotoxicity are not yet available for most of these compounds, which is a limitation of the studies presented in this review about antimicrobial plant lipids. Most studies that tested antimicrobial and cytotoxicity activities from marine lipids are limited to lipid-rich extracts $[145,194]$ or lipid-rich fractions $[97,195]$. For instance, petroleum ether fractions of Grateloupia livida extracts demonstrated a higher antibacterial activity and this fraction did not display acute oral toxicity in mice (100\% survival rate at doses up to $2.0 \mathrm{~g} / \mathrm{Kg}$ ) [195]. Even so, careful conclusions should be taken from these evidences, since petroleum ether is a carcinogenic solvent. The $\mathrm{MeOH}$ and acetone fractions from O. obtusiloba demonstrated activity against HSV-1 and low toxicity to Vero cell (African Green monkey kidney cells) cultures, showing 50\% cytotoxic concentration $\left(\mathrm{CC}_{50}\right)$ of 172 and $>200 \mu \mathrm{g} / \mathrm{mL}$ in $\mathrm{MeOH}$ and acetone fractions, respectively [97]. A sulfolipid-rich fraction from the same red macroalga showed a higher cytotoxicity with $\mathrm{CC}_{50}$ of $72 \mu \mathrm{g} / \mathrm{mL}$ in Vero cell lines [111]. SQDG fractions from S. vulgare with antiviral activity (HSV-1 and HSV-2), displayed $\mathrm{CC}_{50}>200 \mu \mathrm{g} / \mathrm{mL}$ in Vero cells [119]. The ethanolic extract as well as the glycolipid, FA and pigments' fractions from L. cichorioides demonstrated hemolytic activity at $200 \mu \mathrm{g} / \mathrm{mL}$ in erythrocytes of mongrel white mice [91]. SQDG(16:0/16:0) isolated from C. racemosa with antiviral activity (HSV-2) had very low toxicity to Vero cells ATCC CCL-81 with a CC $_{50}$ of $1.0 \mathrm{~g} / \mathrm{mL}$ [95]. An acetylenic FA isolated from the calcareous sponge $P$. cf. waguensis demonstrated weak cytotoxic effect against NBT-T2 rat bladder epithelial cells $\left(\mathrm{IC}_{50}>20 \mathrm{mg} / \mathrm{mL}\right.$ ) [163]. FA mixtures isolated from the sponge A. oroides exhibited in vitro antiplasmodial, trypanocidal, and leishmanicidal activities with weak cytotoxicity toward mammalian (rat skeletal myoblast L6) cells ( $\mathrm{IC}_{50}$ from 43 to $>90 \mu \mathrm{g} / \mathrm{mL}$ ) [162]. Sterols isolated from the sponge $H$. simulans demonstrated anti-mycobacterial and anti-trypanosomal activities, but low cytotoxicity on normal fibroblasts derived from human foreskin (Hs27) cells with $\mathrm{IC}_{50}$ ranges from 58 to $>100 \mu \mathrm{M}$ [170]. Meroterpene sulfate molecules isolated from the sponge Fasciospongia sp. was inactive $\left(\mathrm{IC}_{50}>30 \mu \mathrm{M}\right)$ toward human foreskin fibroblast (HFF-1) cell lines [186]. Finally, lipid extracts from different body compartments (hemolymph, hemocyte, eggs, muscle, and exoskeleton) of four marine crustaceans demonstrated hemolytic activity against human red blood cells, hemolymph and exoskeleton extracts being those that presented the highest activity [149].

Molecules, in this case lipids, with such high MIC values have little chance of undergoing clinical development. Nevertheless, the results of the reviewed reports should allow to focus on the most interesting molecules, having a low MIC value, and reserve the molecules with a high MIC value for other applications, such as veterinary clinic or agriculture. 


\section{Lipidomics for the Analysis of Bioactive Lipids in Plants and in Marine Organisms}

The identification and characterization of lipids as natural antimicrobial agents is of utmost importance, either for their exploitation from natural sources or to understand their mechanisms of action. Lipid identification from natural sources is achieved by using lipidomic strategies. Lipidomics consists in the analysis, identification, and structural characterization of the lipid molecular species from a biological matrix, based on chromatography and MS techniques. It also involves optimizing extraction and fractionation processes, considering the polarity of the different lipids that make up the biological systems. As such, lipidomics is a valuable tool to discover bioactive lipids with antimicrobial activity.

The main phases of the lipidomics workflow include lipid extraction, fractionation, and/or enrichment steps, and analysis of total extracts or lipid fractions by MS combined with LC and/or GC (Figure 3).

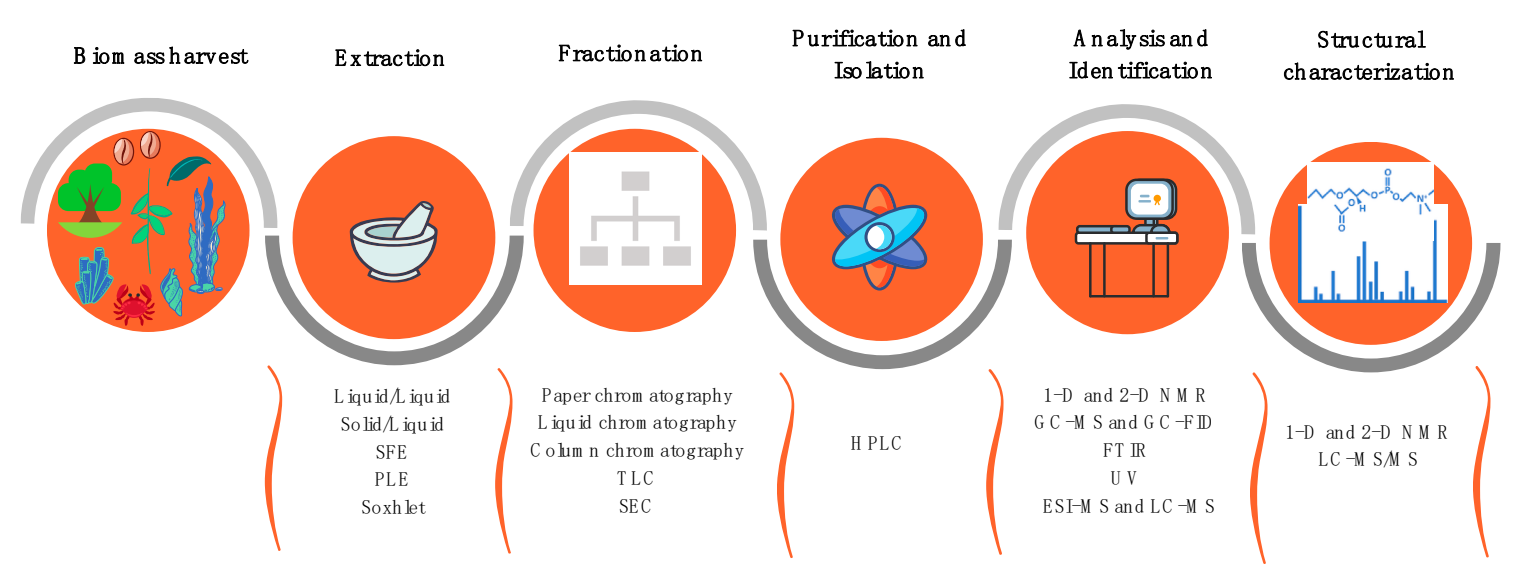

Figure 3. Workflow summarizing the main techniques used for lipidomics analyses of lipids from plants and marine organisms.

Lipid extraction is usually performed with organic solvents. Mixtures of $\mathrm{CHCl}_{3}, \mathrm{MeOH}$, and $\mathrm{H}_{2} \mathrm{O}$ are the most used, such as the Bligh and Dyer [196] or Folch [197] methods and their modifications. These methods are considered the most efficient to extract the total lipid content. However, there are other solvents used for lipid extraction, such as $\mathrm{EtOH}, \mathrm{MeOH}, n$-hexane, $\mathrm{BuOH}$, EtOAc, giving rise to different lipid yields [198,199]. $\mathrm{CHCl}_{3}$ is being replaced by $\mathrm{CH}_{2} \mathrm{Cl}_{2}$ in these methods because the latter is less toxic and allows a similar extraction efficiency. The solvent or the mixture of solvents used in the extraction step(s) exert a great influence in the lipid composition of the extracts obtained from natural sources. In most cases, extractions with different solvents lead to crude extracts with the same components but in different amounts. It is also possible to selectively extract some lipid classes, such as the extraction performed with apolar solvents, as $n$-hexane, which recover mostly apolar lipids (e.g., triacylglycerols). Nevertheless, an effective extraction is very important for the identification of bioactive lipids. Non-conventional methods of extraction as ultrasound- and microwave-assisted extraction or SFE [63] are used to help the extraction, particularly to improve the lipids yield, or to obtain extracts with specific functions and applications. Assisted extraction methods are frequently combined with green solvents, such as EtOH. Soxhlet-assisted extraction with less polar solvents, such as $n$-hexane, is normally used to isolate lipophilic and more apolar lipids, as terpenoids and sterols. Testing potential antimicrobial lipid extracts obtained with different solvents, even from the same source, would provide dissimilar bioactive properties due to different lipid compositions.

Total lipid extracts include a great diversity of lipid classes and molecular species. Fractionation of the total lipid extracts to obtain fractions enriched with specific lipid classes can be achieved by solid-phase extraction (SPE), using columns of simple silica $\left(\mathrm{SPE}-\mathrm{SiO}_{2}\right)$ or functionalized silica, by preparative HPLC, or by TLC, although the latter is less common nowadays. TLC can also be used 
as an identification tool in lipid extracts or fractions, by applying spots of well-known lipid standards in the TLC plate and compare their retention factor with the samples' bands after elution. However, it has the disadvantages of lacking information at lipid molecular level and being time-consuming [200]. A careful choice of the eluents and gradients allows obtaining a selective separation of lipid fractions from the initial extract. The fractions obtained can be used for diverse purposes: to quantify the different lipid classes (e.g., by gravimetry), to separate neutral lipids (e.g., triacylglycerols and sterols) from polar lipids (e.g., phospholipids, glycolipids), or to identify different phospholipid classes, that can be further separated by TLC and estimated by phosphorus quantification of each TLC spot. The lipid fractions can be then used to evaluate the bioactive properties of a specific lipid class and analyzed by GC-MS and/or LC-MS to provide an insight on the structure-activity relationship.

The characterization of total lipids or lipid fractions is done, nowadays, by MS-based approaches using several kinds of mass spectrometers coupled with chromatography. GC-MS is used to identify and quantify FA after derivatization (usually methylation) of apolar lipids as terpenoids and sterols (after derivatization by silylation). GC-MS allows the identification of these molecules by specific retention times, mass spectra analysis, and data base comparison. Nevertheless, GC-MS neither covers large molecules nor non-volatile molecules. Thus, when this approach is used to characterize bioactive lipids, a lot of information is missing. LC-MS allows a broader coverage than GC-MS of lipid species and larger molecules, usually the most abundant ones in the lipid extracts, such as triacylglycerols, polar lipids, or esterified sterols. Besides, small molecules like free FA and free sterols are also detected.

LC-MS identifies the lipid molecular species by their retention time, accurate molecular weight observed in the mass spectra (i.e., LC-MS level), and detailed structural features by interpretation of their LC-MS/MS spectra. The chromatographic peaks are integrated to plot the quantification of each molecular species, which is normalized by an appropriate internal standard to reach a relative quantification. Routine lipidomics analyses use reversed-phase (e.g., C18 or C30), normal-phase, or hydrophilic interaction liquid chromatography (HILIC) columns [200]. In the former, the elution of the lipid molecules is based on their FA composition. So, an overlap of molecular species from different lipid classes but presenting the same FA composition can occur. In the latter two types of columns, the lipid molecules are separated by their hydrophilic properties, allowing to separate the different lipid classes present in the sample, which will depend on the polar head features.

Recent developments in MS technologies permit to acquire a huge amount of data in a short time frame, covering more than three hundred lipid species in one single LC-MS run. This can be done by means of the high-resolution mass spectrometers Orbitrap or quadrupole-time-of-flight (Q-TOF), available for untargeted or targeted analysis, or the triple quadrupoles (QQQ) and Q-traps, that are more suitable for targeted analysis, i.e., quantification of previously selected molecular species. However, data analysis is still time-consuming because of the lack of universal and exhaustive lipidomics databases and software. Some databases and software currently used are the LIPID MAPS database, the MZmine, LipidBlast, LipoStar, LipidSearch, and LPPtiger software.

The identification of bioactive molecules from natural sources is a laborious work that requires performing extraction, bioassays, fractionation, and in some cases, identification, in a sequential way. This is to achieve a specific class of bioactive metabolites or, preferentially, a unique and well-defined bioactive molecule. This process is called bioassay-guided fractionation and is emerging in the field of drug discovery from natural sources [201]. This approach usually starts with different extracts obtained by using solvents with different polarities, in order to have a set of extracts enriched in different types of metabolites. These extracts are evaluated for their putative bioactivities and the one(s) with the highest activity is(are) further fractionated and the new fractions are assayed. The bioassayfractionation-bioassay sequence can go around until a promising candidate molecule or family of molecules are considered and then it is characterized. The first step of fractionation is typically a liquid-liquid extraction (solvent-solvent partition), and normally uses chromatography techniques, as TLC and column chromatography [201-203]. Isolated fractions are assayed afterwards. A final deep characterization using MS and NMR spectroscopy will reveal the exact structure of the bioactive 
molecule(s). This workflow will be a valuable tool to guide new drug discoveries and for understanding the structure-activity relationships. In this regard, lipidomics represents a valuable platform to advance in the characterization of lipid structures, survey lipid pathways, and can help in the elucidation of the interaction of lipids with microorganisms' membranes, because of the high sensitivity and selectivity of MS.

\section{Prospection and Applications of Antimicrobial Lipids}

Several antimicrobial lipids are commercially available or can be used in different formulations in the cosmetic, pharmaceutical, and food industries, as well as in agriculture and aquaculture.

\subsection{Cosmetic and Drug Formulations}

In cosmetics, the free FA 10:0 and 12:0 and their corresponding MAG, monocaprin MAG(10:0) and monolaurin MAG(12:0), respectively, are commonly used in topical applications [21]. As a general rule, the esterification of free FA to glycerol increases the antimicrobial activity [127]. MAG(10:0) has been suggested as an ingredient for drug formulations to avoid oral infections by C. albicans [204].

\subsection{Food Additives}

The free FA 8:0 (commercial lipid standard) was shown to be effective against E. coli, Salmonella and other foodborne pathogens [21]. MAG(10:0) is known as a safe food additive, widely used as an emulsifier in the food industry [205].

Lipid extracts from marine organisms demonstrated to be a source of antibacterial compounds. The FA 16:1 inhibited the growth of the foodborne pathogens Bacillus cereus and B. weihenstephanensis [125]. Extracts from the microalga D. salina inhibited the growth of important food industry pathogens (i.e., E. coli, S. aureus, C. albicans, and A. niger) [123]. EPA, a high abundant PUFA in marine species, presented a potent action against the foodborne pathogen $B$. cereus, likely by disrupting the pathogen's cell membrane, ultimately leading to cell lysis [206].

\subsection{Herbicides and Pesticides}

Some studies evaluated the antimicrobial activity of plants' lipid extracts against both phytopathogenic fungi and bacteria. The sphingolipid $\left[(2 S, 3 S, 4 R, 10 E)-2-\left[\left(2^{\prime} R\right)-2\right.\right.$-hydroxytetracosanoylamino $]-1,3,4-$ octadecanetriol-10-ene], a low polarity aglycone isolated from cucumber (C. sativus) stems, had strong antibacterial and antifungal activity against plant pathogens [74]. A mixture of lipids (FA, FAME, squalene, and $\beta$-sitosterol) extracted from andiroba (Carapa sp.) seeds demonstrated a MIC range of 156-250 $\mu \mathrm{g} / \mathrm{mL}$ against several phytopathogenic fungi: A. flavus, A. niger and F. oxysporum [58]. Antimicrobial compounds from plants are envisioned as eco-friendly alternatives to chemical pesticides that harm both the environment and public health [58], because of their structural diversity, unique bioactivity, and environmental compatibility [74]. It is, thus, necessary to invest in a new approach to understand the mode of action of antimicrobial lipids isolated from plants in microbial cells.

Marine macroalgae have been traditionally used by several populations as soil fertilizers in agriculture, enriching them with minerals and plant growth promoters. The presence of antimicrobial molecules in macroalgae may contribute to develop biologically active compounds that protect agricultural crops toward pathogenic bacteria and fungi. This is the case of the sulfolipids isolated from the brown macroalga $S$. wightii that showed activity against the Gram-negative bacterium Xanthomonas oryzae pv. oryzae that causes the bacterial blight of rice [120]. Specific glycolipids, termed caminosides, isolated from the marine sponge $C$. sphaeroconia were active against the plant pathogen Pythium ultimum, the cause of damping off and root rot diseases in food crops and ornamental species [176]. Three sesterterpenes identified in the sponge Thorectandra sp. showed high inhibitory effect against the plant pathogenic fungus Cladosporium herbarum [190].

A recent study has mapped soil-borne fungal plant pathogens and projected their distribution under different climate change and soil uses scenarios [207]. The most dominant pathogens that 
harm global crop production belong to the genera Alternaria and Fusarium [207]. Enriched fractions of glycolipids from the macroalgae L. cichorioides and S. pallidum, as well as free FA and PUFA fractions from L. cichorioides, and FA esters, triacylgycerols/free sterols, free sterols and diacylglycerol fractions from S. pallidum demonstrated activity against the fungus F. oxysporum [91,118]. Lipid fractions with several steroid compounds from the oyster S. glomerata were very active against Fusarium sp. [171]. A bioprospection study in macroalgae of the order Caulerpales isolated ten sesquiterpenoids and diterpenoids and tested their activity in several bacterium and fungi strains. Eight of these compounds inhibited the growth of Alternaria sp. [98].

The free FA 10:0, 12:0, and their corresponding MAG [MAG(10:0) and MAG(12:0)], likewise as for cosmetic applications as mentioned above, are also used in agriculture crops as herbicides [21].

\subsection{Aquaculture}

Nowadays, aquaculture production accounts for almost half of the animal and aquatic plants catches, with 82 million tons [208]. Aquaculture represents an important food production sector, so finding environmental-friendly compounds with antibiotic activity instead of synthetic drugs is of utmost importance. This is even more urgent if we consider that, although vaccination is the best alternative to prevent infectious diseases in general, in aquaculture it is not likely to protect juvenile fish (without a mature immune system), shrimp, and bivalves (without an adaptive immune system, only with innate system), which are the most affected aquaculture animals by infectious diseases.

Several antimicrobial compounds identified in marine organisms are salt-tolerant [14] and have demonstrated to be efficient against aquaculture-relevant pathogens such as Listonella anguillarum, Lactococcus garvieae, and Vibrio species, showing advantage in pathogen control of fish and shellfish farming [99,108,112,125,126,209]. Extracts of Falkenbergia, a heteromorphic sporophyte of Asparagopsis taxiformis, inhibited the growth of several fish and shrimp Vibrio pathogens [106]. The FA 16:3 n-4 (HTA) isolated from the diatom P. tricornutum inhibited the growth of the Gram-negative marine pathogenic bacterium L. anguillarum [125]. A lipid fraction of the oyster S. glomerata extract inhibited the shrimp white spot syndrome virus (WSSV) in Fenneropenaeus indicus [171].

\section{Conclusions}

Lipids isolated from plants and marine organisms have demonstrated a broad spectrum of antimicrobial activities. These biomolecules can be envisaged as a promising alternative to help control pathogenic microbial infections. They have shown positive results in in vitro studies and microorganisms do not develop resistance to them, as far as it is known. However, the study of natural sources-derived antimicrobial lipids presents yet some shortcomings. There is a low number of systematic studies performing the isolation of pure lipid molecular species and their structural characterization, since they are mainly studied as complex extracts. There is also a lack of in vivo tests, indispensable to understand their mechanism of action, their cytotoxicity to eukaryotic cells, and consequently allowing their use at a large scale. Lipidomics is a fundamental tool to advance in the characterization of lipid structures and elucidate the lipids-microorganisms' interaction. This can be achieved along with complementary biophysical, spectroscopic, and spectrometric studies that will be useful to understand their mechanism of action toward microbes and to define the structure-activity relationship. In addition, it is necessary to study the synergistic effects of these compounds against a wide range of microorganisms' species to evidence broad-spectrum effects. The bioprospection of new natural lipids will benefit from the association among complementary research areas and the industry. Furthermore, the potential applications of antimicrobial lipids in different economic sectors, such as pharmaceutical, cosmetics, agriculture, or aquaculture, are still underexplored. So, the combination of these natural resources with sophisticated analytical tools applied to lipidomics research will open new perspectives on antimicrobial lipids for clinical and non-clinical applications. It is hoped that the future could bring about a greater interaction between lipidomics and natural chemotherapy to reveal the true microbicidal action of lipids toward pathogens. More studies must be done to 
understand which lipids can effectively be responsible by the inhibitory or microbicidal effect and their structure-activity relationship.

Author Contributions: Conceptualization and study design, E.A., F.R., and M.d.R.D.; literature search and review, E.A., F.R., M.D., and D.L.; writing-original draft preparation, E.A., F.R., and M.d.R.D.; writing-review and editing, E.A., F.R., M.d.R.D., A.A.; formatting and design-D.L.; supervision, A.A. and M.d.R.D. All authors read and approved the final version of the manuscript.

Funding: The authors acknowledge the University of Aveiro, Fundação para a Ciência e a Tecnologia (FCT, Portugal) and Ministério da Ciência e Tecnologia (MCT) for the financial support for the Química Orgânica, Produtos Naturais e Agroalimentares (QOPNA) research Unit (FCT UID/QUI/00062/2019), LAQV-REQUIMTE (FCT UIDB/50006/2020) and CESAM [UIDB/50017/2020.UIDP/50017/2020] through national founds and, where applicable, co-financed by the European Regional Development Fund (FEDER), within the Portugal 2020 Partnership Agreement, and to the Portuguese Mass Spectrometry Network (RNEM, LISBOA-01-0145-FEDER-402-022125). Thanks are also due to FCT/MCT through national funds (PIDDAC), and the co-funding by FEDER, within the Portugal 2020 Partnership Agreement and Programa Operacional Temático Factores de Competitividade (COMPETE) 2020. Diana Lopes (reference SFRH/BD/119027/2016) is grateful to FCT, Programa Operacional do Capital Humano (POCH) and European Union through European Social Fund (FSE) for her PhD grant. This work was also funded by national funds, through FCT, in the scope of the Individual Call to Scientific Employment Stimulus 2017 with a Junior Researcher contract to Eliana Alves (reference CEECIND/00971/2017) and to Felisa Rey (reference CEECIND/00580/2017).

Conflicts of Interest: The authors declare no conflict of interest.

\section{Abbreviations}

\begin{tabular}{|c|c|}
\hline AMP & Antimicrobial peptide \\
\hline AMR & Antimicrobial resistance \\
\hline $\mathrm{BuOH}$ & Butanol \\
\hline $\mathrm{CC}$ & Cytotoxic concentration \\
\hline $\mathrm{CH}_{2} \mathrm{Cl}_{2}$ & Dichloromethane \\
\hline $\mathrm{CHCl}_{3}$ & Chloroform \\
\hline CLSI & Clinical and Laboratory Standards Institute (formerly NCCLS) \\
\hline COSY & Correlation spectroscopy \\
\hline CRE & Carbapenemase-resistant Enterobacteriaceae \\
\hline DAG & Diacylglycerol \\
\hline DGDG & Digalactosyldiacylglycerol \\
\hline DOX & Dioxygenase \\
\hline DPA & Docosapentaenoic \\
\hline EC & Effective concentration \\
\hline EPA & Eicosapentaenoic acid \\
\hline ESBL & Extended-spectrum beta-lactamase \\
\hline ESI-MS & Electrospray ionization-mass spectrometry \\
\hline ESI-MS/MS & Electrospray ionization-tandem mass spectrometry \\
\hline ETA & Eicosatetraenoic acid \\
\hline $\mathrm{Et}_{2} \mathrm{O}$ & Diethyl ether \\
\hline EtOAc & Ethyl acetate \\
\hline $\mathrm{EtOH}$ & Ethanol \\
\hline FA & Fatty acid \\
\hline FAB-MS & Fast atom bombardment-mass spectrometry \\
\hline FAME & Fatty acid methyl ester \\
\hline FIA-MS & Flow-injection analysis-mass spectrometry \\
\hline FT-NMR & Fourier transformed-nuclear magnetic resonance \\
\hline $\mathrm{G}(-)$ & Gram-negative \\
\hline $\mathrm{G}(+)$ & Gram-positive \\
\hline GC & Gas-phase chromatography \\
\hline GC-FID & Gas-phase chromatography-flame ionization detector \\
\hline GC-MS & Gas-phase chromatography-mass spectrometry \\
\hline GlCer & Glucosylceramide \\
\hline GRAS & Generally recognized as safe \\
\hline
\end{tabular}




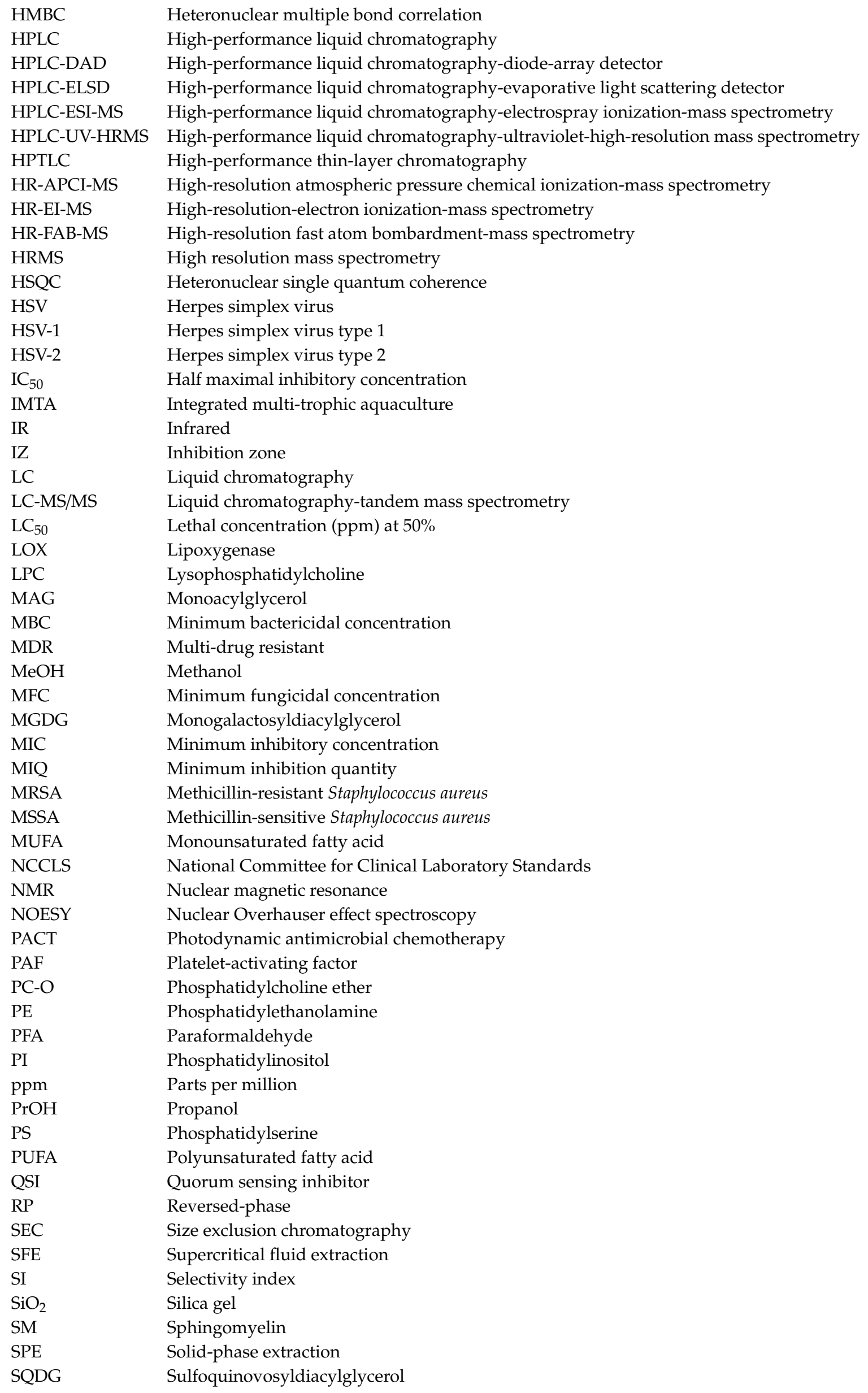


TI

TLC

UFA

VII

WHO
Therapeutic index

Thin-layer chromatography

Unsaturated fatty acid

Viral inhibition index

World Health Organization

\section{References}

1. Mikulic, M. Total Consumption of Antibiotics in WHO Countries in 2016 (In Metric Tons). Available online: https://www.statista.com/statistics/949926/consumed-amount-of-antibiotics-in-who-countries/ (accessed on 20 February 2020).

2. World Health Organization. Antimicrobial Resistance. Available online: https://www.who.int/news-room/ fact-sheets/detail/antimicrobial-resistance (accessed on 3 March 2020).

3. World Health Organization. New Report Calls for Urgent Action to Avert Antimicrobial Resistance Crisis. Available online: https://www.who.int/news-room/detail/29-04-2019-new-report-calls-for-urgent-action-toavert-antimicrobial-resistance-crisis (accessed on 4 March 2020).

4. World Health Organization. Global Priority List of Antibiotic-Resistant Bacteria to Guide Research, Discovery, and Development of New Antibiotics. Available online: https://www.who.int/medicines/publications/WHOPPL-Short_Summary_25Feb-ET_NM_WHO.pdf (accessed on 3 March 2020).

5. Mulani, M.S.; Kamble, E.E.; Kumkar, S.N.; Tawre, M.S.; Pardesi, K.R. Emerging strategies to combat ESKAPE pathogens in the era of antimicrobial resistance: A Review. Front. Microbiol. 2019, 10, 539. [CrossRef] [PubMed]

6. Cassini, A.; Hogberg, L.; Plachouras, D.; Quattrocchi, A.; Hoxha, A.; Simonsen, G.; Colomb-Cotinat, M.; Kretzschmar, M.; Devleesschauwer, B.; Cecchini, M.; et al. Attributable deaths and disability-adjusted life-years caused by infections with antibiotic-resistant bacteria in the EU and the European Economic Area in 2015: A population-level modelling analysis. Lancet Infect. Dis. 2019, 19, 56-66. [CrossRef]

7. McCarthy, N. Antibiotic Resistance-Superbugs Kill 33,000 Europeans Every Year. Available online: https: //www.statista.com/chart/16012/median-number-of-deaths-due-to-antibiotic-resistance-bacteria/ (accessed on 3 March 2020).

8. World Health Organization. No Time to Wait: Securing the Future from Drug-Resistant Infections. Report to the Secretary-General of the United Nations. Available online: https://www.who.int/antimicrobial-resistance/ interagency-coordination-group/final-report/en/ (accessed on 4 March 2020).

9. World Health Organization. Lack of New Antibiotics Threatens Global Efforts to Contain Drug-Resistant Infections. Available online: https://www.who.int/news-room/detail/17-01-2020-lack-of-new-antibioticsthreatens-global-efforts-to-contain-drug-resistant-infections (accessed on 3 March 2020).

10. Alves, E.; Faustino, M.A.F.; Neves, M.G.P.M.S.; Cunha, A.; Tome, J.; Almeida, A. An insight on bacterial cellular targets of photodynamic inactivation. Future Med. Chem. 2014, 6, 141-164. [CrossRef] [PubMed]

11. Alves, E.; Faustino, M.A.F.; Neves, M.G.P.M.S.; Cunha, A.; Nadais, H.; Almeida, A. Potential applications of porphyrins in photodynamic inactivation beyond the medical scope. J. Photochem. Photobiol. C 2015, 22, 34-57. [CrossRef]

12. Almeida, A.; Cunha, A.; Gomes, N.C.M.; Alves, E.; Costa, L.; Faustino, M.A.F. Phage therapy and photodynamic therapy: Low environmental impact approaches to inactivate microorganisms in fish farming plants. Mar. Drugs 2009, 7, 268-313. [CrossRef]

13. Ghosh, C.; Sarkar, P.; Issa, R.; Haldar, J. Alternatives to conventional antibiotics in the era of antimicrobial resistance. Trends Microbiol. 2019, 27, 323-338. [CrossRef]

14. Hughes, C.C.; Fenical, W. Antibacterials from the sea. Chemistry 2010, 16, 12512-12525. [CrossRef]

15. Gray, D.A.; Wenzel, M. Multitarget approaches against multiresistant superbugs. ACS Infect. Dis. 2020, 6, 1346-1365. [CrossRef]

16. Smith, V.J.; Desbois, A.P.; Dyrynda, E.A. Conventional and unconventional antimicrobials from fish, marine invertebrates and micro-algae. Mar. Drugs 2010, 8, 1213-1262. [CrossRef]

17. Shannon, E.; Abu-Ghannam, N. Antibacterial derivatives of marine algae: An overview of pharmacological mechanisms and applications. Mar. Drugs 2016, 14, 81. [CrossRef] 
18. Hayashi, M.A.; Bizerra, F.C.; Da Silva, P.I. Antimicrobial compounds from natural sources. Front. Microbiol. 2013, 4, 195. [CrossRef] [PubMed]

19. Khameneh, B.; Iranshahy, M.; Soheili, V.; Fazly Bazzaz, B.S. Review on plant antimicrobials: A mechanistic viewpoint. Antimicrob. Resist. Infect. Control. 2019, 8, 118. [CrossRef] [PubMed]

20. Yoon, B.K.; Jackman, J.A.; Valle-González, E.R.; Cho, N.J. Antibacterial free fatty acids and monoglycerides: Biological activities, experimental testing, and therapeutic applications. Int. J. Mol. Sci. 2018, $19,1114$. [CrossRef] [PubMed]

21. McGaw, L.J.; Jäger, A.K.; Van Staden, J. Antibacterial effects of fatty acids and related compounds from plants. S. Afr. J. Bot. 2002, 68, 417-423. [CrossRef]

22. Bergsson, G.; Hilmarsson, H.; Thormar, H. Chapter 3-Antibacterial, antiviral and antifungal activities of lipids. In Lipids and Essential Oils as Antimicrobial Agents; Thormar, H., Ed.; Wiley: Chichester, UK, 2010; pp. 47-80.

23. Pasdaran, A.; Hamedi, A. Chapter 14-Natural products as source of new antimicrobial compounds for skin infections. In The Microbiology of Skin, Soft Tissue, Bone and Joint Infections; Kon, K., Rai, M., Eds.; Academic Press: Cambridge, MA, USA, 2017; pp. 223-253.

24. Hemaiswarya, S.; Kruthiventi, A.K.; Doble, M. Synergism between natural products and antibiotics against infectious diseases. Phytomedicine 2008, 15, 639-652. [CrossRef]

25. Stefanović, O.D. Synergistic activity of antibiotics and bioactive plant extracts: A study against Gram-positive and Gram-negative bacteria. In Bacterial Pathogenesis and Antibacterial Control; Kırmusaoğlu, S., Ed.; IntechOpen: London, UK, 2018; pp. 23-48.

26. De Menezes, C.B.A.; Afonso, R.S.; de Souza, W.R.; Parma, M.M.; de Melo, I.S.; Fugita, F.L.S.; Moraes, L.A.B.; Zucchi, T.D.; Fantinatti-Garboggini, F. Williamsia aurantiacus sp. nov. a novel actinobacterium producer of antimicrobial compounds isolated from the marine sponge. Arch. Microbiol. 2019, 201, 691-698. [CrossRef]

27. Ismail, A.; Ktari, L.; Ahmed, M.; Bolhuis, H.; Boudabbous, A.; Stal, L.J.; Cretoiu, M.S.; El Bour, M. Antimicrobial activities of bacteria associated with the brown alga Padina pavonica. Front. Microbiol. 2016, 7, 1072. [CrossRef]

28. Haq, A.; Siddiqi, M.; Batool, S.; Islam, A.; Khan, A.; Khan, D.; Khan, S.; Khan, H.; Shah, A.; Hasan, F.; et al. Comprehensive investigation on the synergistic antibacterial activities of Jatropha curcas pressed cake and seed oil in combination with antibiotics. AMB Express 2019, 9, 67. [CrossRef]

29. Desbois, A.P.; Lawlor, K.C. Antibacterial activity of long-chain polyunsaturated fatty acids against Propionibacterium acnes and Staphylococcus aureus. Mar. Drugs 2013, 11, 4544-4557. [CrossRef]

30. Lee, K.Y.; Jeong, M.R.; Choi, S.M.; Na, S.S.; Cha, J.D. Synergistic effect of fucoidan with antibiotics against oral pathogenic bacteria. Arch. Oral Biol. 2013, 58, 482-492. [CrossRef]

31. Kawabata, S.; Nagayama, R.; Hirata, M.; Shigenaga, T.; Agarwala, K.L.; Saito, T.; Cho, J.; Nakajima, H.; Takagi, T.; Iwanaga, S. Tachycitin, a small granular component in horseshoe crab hemocytes, is an antimicrobial protein with chitin-binding activity. J. Biochem. 1996, 120, 1253-1260. [CrossRef] [PubMed]

32. Lee, J.; Eom, S.; Lee, E.; Jung, Y.; Kim, H.; Jo, M.; Son, K.; Lee, H.; Kim, J.; Lee, M.; et al. In vitro antibacterial and synergistic effect of phlorotannins isolated from edible brown seaweed Eisenia bicyclis against acne-related bacteria. Algae 2014, 29, 47-55. [CrossRef]

33. He, X.; Hwang, H.M.; Aker, W.G.; Wang, P.; Lin, Y.; Jiang, X. Synergistic combination of marine oligosaccharides and azithromycin against Pseudomonas aeruginosa. Microbiol. Res. 2014, 169, 759-767. [CrossRef]

34. Ebada, S.S.; Lin, W.; Proksch, P. Bioactive sesterterpenes and triterpenes from marine sponges: Occurrence and pharmacological significance. Mar. Drugs 2010, 8, 313-346. [CrossRef]

35. Pohl, C.H.; Kock, J.L.; Thibane, V.S. Antifungal free fatty acids: A review. In Science Against Microbial Pathogens: Communicating Current Research and Technological Advances; Mendéz-Vilas, A., Ed.; Formatex Research Center: Badajoz, Spain, 2011; pp. 61-71.

36. Silhavy, T.J.; Kahne, D.; Walker, S. The bacterial cell envelope. Cold Spring Harb. Perspect. Biol. $2010,2$. [CrossRef] [PubMed]

37. Epand, R.; Epand, R. Lipid domains in bacterial membranes and the action of antimicrobial agents. Biochim. Biophys. Acta 2009, 1788, 289-294. [CrossRef] [PubMed]

38. Li, X.C.; Jacob, M.R.; ElSohly, H.N.; Nagle, D.G.; Smillie, T.J.; Walker, L.A.; Clark, A.M. Acetylenic acids inhibiting azole-resistant Candida albicans from Pentagonia gigantifolia. J. Nat. Prod. 2003, 66, 1132-1135. [CrossRef] [PubMed] 
39. Ells, R.; Kock, J.L.; Van Wyk, P.W.; Botes, P.J.; Pohl, C.H. Arachidonic acid increases antifungal susceptibility of Candida albicans and Candida dubliniensis. J. Antimicrob. Chemother. 2009, 63, 124-128. [CrossRef]

40. Sjögren, J.; Magnusson, J.; Broberg, A.; Schnürer, J.; Kenne, L. Antifungal 3-hydroxy fatty acids from Lactobacillus plantarum MiLAB 14. Appl. Environ. Microbiol. 2003, 69, 7554-7557. [CrossRef]

41. Dilika, F.; Bremner, P.; Meyer, J. Antibacterial activity of linoleic and oleic acids isolated from Helichrysum pedunculatum: A plant used during circumcision rites. Fitoterapia 2000, 71, 450-452. [CrossRef]

42. Sun, C.; O'Connor, C.; Roberton, A. Antibacterial actions of fatty acids and monoglycerides against Helicobacter pylori. FEMS Immunol. Med. Microbiol. 2003, 36, 9-17. [CrossRef]

43. Davies, J.; Davies, D. Origins and evolution of antibiotic resistance. Microbiol. Mol. Biol. Rev. 2010, 74, 417-433. [CrossRef] [PubMed]

44. Tiku, A.R. Antimicrobial compounds (phytoanticipins and phytoalexins) and their role in plant defense. In Co-Evolution of Secondary Metabolites. Reference Series in Phytochemistry; Mérillon, J.M., Ramawat, K., Eds.; Springer: Cham, Switzerland, 2020; pp. 845-868.

45. Prost, I.; Dhondt, S.; Rothe, G.; Vicente, J.; Rodriguez, M.J.; Kift, N.; Carbonne, F.; Griffiths, G.; Esquerré-Tugayé, M.T.; Rosahl, S.; et al. Evaluation of the antimicrobial activities of plant oxylipins supports their involvement in defense against pathogens. Plant Physiol. 2005, 139, 1902-1913. [CrossRef] [PubMed]

46. Blee, E. Impact of phyto-oxylipins in plant defense. Trends Plant. Sci. 2002, 7, 315-321. [CrossRef]

47. Feussner, I.; Wasternack, C. The lipoxygenase pathway. Annu. Rev. Plant. Biol. 2002, 53, 275-297. [CrossRef]

48. Deboever, E.; Deleu, M.; Mongrand, S.; Lins, L.; Fauconnier, M.L. Plant-pathogen interactions: Underestimated roles of phyto-oxylipins. Trends Plant. Sci. 2020, 25, 22-34. [CrossRef]

49. D’Oca, C.; Coelho, T.; Marinho, T.; Hack, C.; Duarte, R.; da Silva, P.; D’Oca, M. Synthesis and antituberculosis activity of new fatty acid amides. Bioorg. Med. Chem. Lett. 2010, 20, 5255-5257. [CrossRef]

50. Dembitsky, V.; Shkrob, I.; Rozentsvet, O. Fatty acid amides from freshwater green alga Rhizoclonium hieroglyphicum. Phytochemistry 2000, 54, 965-967. [CrossRef]

51. Gopalakrishnan, S.; Srinivas, V.; Alekhya, G.; Prakash, B.; Kudapa, H.; Varshney, R. Evaluation of broad-spectrum Streptomyces sp. for plant growth promotion traits in chickpea (Cicer arietinum L.). Philipp. Agric. Sci. 2015, 98, 270-278.

52. Tanvir, R.; Javeed, A.; Rehman, Y. Fatty acids and their amide derivatives from endophytes: New therapeutic possibilities from a hidden source. FEMS Microbiol. Lett. 2018, 365. [CrossRef]

53. Gunstone, F.D.; Harwood, J.L. Occurrence and characterisation of oils and fats. In The Lipid Handbook with CD-ROM, 3rd ed.; Gunstone, F.D., Harwood, J.L., Dijkstra, A.J., Eds.; CRC Press: Boca Raton, FL, USA, 2007; pp. 51-156.

54. Fafal, T.; Yilmaz, F.F.; Birincioğlu, S.S.; Hoşgör-Limoncu, M.; Kivçak, B. Fatty acid composition and antimicrobial activity of Asphodelus aestivus seeds. Hum. Vet. Med. 2016, 8, 103-107.

55. Shukla, S.; Hegde, S.; Kumar, A.; Chaudhary, G.; Tewari, K.; Upreti, D.; Pal, M. Fatty acid composition and antibacterial potential of Cassia tora (leaves and stem) collected from different geographic areas of India. J. Food Drug Anal. 2018, 26, 107-111. [CrossRef] [PubMed]

56. Sati, A.; Sati, S.; Sati, N.; Sati, O. Chemical composition and antimicrobial activity of fatty acid methyl ester of Quercus leucotrichophora fruits. Nat. Prod. Res. 2017, 31, 713-717. [CrossRef] [PubMed]

57. Abdelillah, A.; Houcine, B.; Halima, D.; Meriel, C.S.; Imane, Z.; Eddine, S.D.; Abdallah, M.; Daoudi, C.S. Evaluation of antifungal activity of free fatty acids methyl esters fraction isolated from Algerian Linum usitatissimum L. seeds against toxigenic Aspergillus. Asian Pac. J. Trop. Biomed. 2013, 3, 443-448. [CrossRef]

58. Nascimento, G.; Souza, D.; Santos, A.; Batista, J.; Rathinasabapathi, B.; Gagliardi, P.; Goncalves, J. Lipidomic profiles from seed oil of Carapa guianensis Aubl. and Carapa vasquezii Kenfack and implications for the control of phytopathogenic fungi. Ind. Crops Prod. 2019, 129, 67-73. [CrossRef]

59. Sasmakov, S.; Gazizov, F.; Putieva, Z.; Wende, K.; Alresly, Z.; Lindequist, U. Neutral lipids, phospholipids, and biological activity of extracts from Zygophyllum oxianum. Chem. Nat. Compd. 2012, 48, 11-15. [CrossRef]

60. Chandrasekaran, M.; Senthilkumar, A.; Venkatesalu, V. Antibacterial and antifungal efficacy of fatty acid methyl esters from the leaves of Sesuvium portulacastrum L. Eur. Rev. Med. Pharmacol. Sci. 2011, 15, 775-780.

61. Chandrasekaran, M.; Kannathasan, K.; Venkatesalu, V. Antimicrobial activity of fatty acid methyl esters of some members of Chenopodiaceae. Z. Für Naturforsch. C J. Biosci. 2008, 63, 331-336. [CrossRef] 
62. Agoramoorthy, G.; Chandrasekaran, M.; Venkatesalu, V.; Hsu, M.J. Antibacterial and antifungal activities of fatty acid methyl esters of the blind-your-eye mangrove from India. Braz. J. Microbiol. 2007, 38, 739-742. [CrossRef]

63. Basa'ar, O.; Fatema, S.; Alrabie, A.; Mohsin, M.; Farooqui, M. Supercritical carbon dioxide extraction of Triognella foenum graecum Linn seeds: Determination of bioactive compounds and pharmacological analysis. Asian Pac. J. Trop. Biomed. 2017, 7, 1085-1091. [CrossRef]

64. Kannathasan, K.; Senthilkumar, A.; Venkatesalu, V.; Chandrasekaran, M. Larvicidal activity of fatty acid methyl esters of Vitex species against Culex quinquefasciatus. Parasitol. Res. 2008, 103, 999-1001. [CrossRef] [PubMed]

65. Trapp, M.; Kai, M.; Mithofer, A.; Rodrigues, E. Antibiotic oxylipins from Alternanthera brasiliana and its endophytic bacteria. Phytochemistry 2015, 110, 72-82. [CrossRef] [PubMed]

66. Sundar, R.D.V.; Segaran, G.; Shankar, S.; Settu, S.; Ravi, L. Bioactivity of Phoenix dactylifera seed and its phytochemical analysis. Int. J. Green Pharm. 2017, 11, S292-S297. [CrossRef]

67. Singh, G.; Kumar, P.; Jindal, A. Antibacterial potential of sterols of some medicinal plants. Int. J. Pharm. Pharm. Sci. 2012, 43, 159-3162.

68. Wikaningtyas, P.; Sukandar, E.Y. The antibacterial activity of selected plants towards resistant bacteria isolated from clinical specimens. Asian Pac. J. Trop. Biomed. 2016, 6, 16-19. [CrossRef]

69. Wong, K.; Ali, D.; Boey, P. Chemical constituents and antibacterial activity of Melastoma malabathricum L. Nat. Prod. Res. 2012, 26, 609-618. [CrossRef]

70. Salvador, M.; Ferreira, E.; Pral, E.; Alfieri, S.; Albuquerque, S.; Ito, I.; Dias, D. Bioactivity of crude extracts and some constituents of Blutaparon portulacoides (Amaranthaceae). Phytomedicine 2002, 9, 566-571. [CrossRef]

71. Bharitkar, Y.P.; Bathini, S.; Ojha, D.; Ghosh, S.; Mukherjee, H.; Kuotsu, K.; Chattopadhyay, D.; Mondal, N.B. Antibacterial and antiviral evaluation of sulfonoquinovosyldiacylglyceride: A glycolipid isolated from Azadirachta indica leaves. Lett. Appl. Microbiol. 2014, 58, 184-189. [CrossRef]

72. Ash, A.; Bharitkar, Y.; Murmu, S.; Hazra, A.; Ravichandiran, V.; Kar, P.; Mondal, N. Ultrastructural changes in Raillietina (Platyhelminthes: Cestoda), exposed to sulfonoquinovosyldiacylglyceride (SQDG), isolated from Neem (Azadirachta indica). Nat. Prod. Res. 2017, 31, 2445-2449. [CrossRef]

73. Rashid, M.U.; Alamzeb, M.; Ali, S.; Khan, A.; Igoli, J.; Ferro, V.; Gray, A.; Khan, M. A new ceramide along with eight known compounds from the roots of Artemisia incisa Pamp. Rec. Nat. Prod. 2015, 9, 297-304.

74. Tang, J.; Meng, X.; Liu, H.; Zhao, J.; Zhou, L.; Qiu, M.; Zhang, X.; Yu, Z.; Yang, F. Antimicrobial activity of sphingolipids isolated from the stems of cucumber (Cucumis sativus L.). Molecules 2010, 15, 9288-9297. [CrossRef] [PubMed]

75. Khedr, A.; Ibrahim, S.; Mohamed, G.; Ross, S.; Yamada, K. Panduramides A-D, new ceramides from Ficus pandurata fruits. Phytochem. Lett. 2018, 23, 100-105. [CrossRef]

76. Poumale, H.; Djoumessi, A.; Ngameni, B.; Sandjo, L.; Ngadjui, B.; Shiono, Y. A new ceramide isolated from Ficus lutea Vahl (Moraceae). Acta Chim. Slov. 2011, 58, 81-86. [PubMed]

77. Wyatt, R.; Hodges, L.; Kalafatis, N.; Wright, P.; Wynne, P.; Macrides, T. Phytochemical analysis and biological screening of leaf and twig extracts from Kunzea ericoides. Phytother. Res. 2005, 19, 963-970. [CrossRef]

78. Allaoua, Z.; Benkhaled, M.; Dibi, A.; Long, C.; Aberkane, M.C.; Bouzidi, S.; Kassah-Laouar, A.; Haba, H. Chemical composition, antioxidant and antibacterial properties of Pteranthus dichotomus from Algerian Sahara. Nat. Prod. Res. 2016, 30, 700-704. [CrossRef]

79. Abubakar, M.N.; Majinda, R.R.T. GC-MS Analysis and preliminary antimicrobial activity of Albizia adianthifolia (Schumach) and Pterocarpus angolensis. Medicines 2016, 3, 3. [CrossRef]

80. Keroletswe, N.; Majinda, R.R.T.; Masesane, I.B. A new 3-prenyl-2-flavene and other extractives from Baphia massaiensis and their antimicrobial activities. Nat. Prod. Commun. 2018, 13, 435-438. [CrossRef]

81. Semwal, P.; Painuli, S.; Badoni, H.; Bacheti, R.K. Screening of phytoconstituents and antibacterial activity of leaves and bark of Quercus leucotrichophora A. Camus from Uttarakhand Himalaya. Clin. Phytosci. 2018, 4, 30. [CrossRef]

82. Sanusi, S.B.; Bakar, M.A.; Mohamed, M.; Sabran, S.F.; Azizul, I. Antibacterial Activity and Phytochemical Analysis of Kembang semangkok (Scaphium macropodum) Stem Bark. In IOP Conference Series: Earth and Environmental Science, Proceedings of International Conference on Biodiversity; Takzim, J.D., Ed.; IOP Publishing: Bristol, UK, 2018; p. 12043. [CrossRef] 
83. Nguyen, H.; Ho, D.; Vo, H.; Le, A.; Nguyen, H.; Kodama, T.; Ito, T.; Morita, H.; Raal, A. Antibacterial activities of chemical constituents from the aerial parts of Hedyotis pilulifera. Pharm. Biol. 2017, 55, 787-791. [CrossRef]

84. Chatterjee, R.; Singh, O.; Pachuau, L.; Malik, S.P.; Paul, M.; Bhadra, K.; Paul, S.; Kumar, G.S.; Mondal, N.B.; Banerjee, S. Identification of a sulfonoquinovosyldiacylglyceride from Azadirachta indica and studies on its cytotoxic activity and DNA binding properties. Bioorg. Med. Chem. Lett. 2010, 20, 6699-6702. [CrossRef]

85. Yogesh, P.; Bhattacharya, S.; Das, T.; Roy, M.; Besra, S.; Gomes, A.; Mondal, N.; Banerjee, S. Anti-leukemic activity of sulfonoquinovosyldiacylglyceride (SQDG): A constituent of Azadirachta indica leaves. Med. Chem. Res. 2013, 22, 22-27. [CrossRef]

86. Bachere, E.; Gueguen, Y.; Gonzalez, M.; de Lorgeril, J.; Garnier, J.; Romestand, B. Insights into the anti-microbial defense of marine invertebrates: The penaeid shrimps and the oyster Crassostrea gigas. Immunol. Rev. 2004, 198, 149-168. [CrossRef]

87. Bhadury, P.; Wright, P. Exploitation of marine algae: Biogenic compounds for potential antifouling applications. Planta 2004, 219, 561-578. [CrossRef] [PubMed]

88. Mayer, A.; Rodriguez, A.; Taglialatela-Scafati, O.; Fusetani, N. Marine Pharmacology in 2012-2013: Marine compounds with antibacterial, antidiabetic, antifungal, anti-inflammatory, antiprotozoal, antituberculosis, and antiviral activities; affecting the immune and nervous systems, and other miscellaneous mechanisms of action. Mar. Drugs 2017, 15, 273. [CrossRef]

89. El Baz, F.; El Baroty, G.; Abd El Baky, H.; Abd El-Salam, O.; Ibrahim, E. Structural characterization and biological activity of sulfolipids from selected marine algae. Grasas Aceites 2013, 64, 561-571. [CrossRef]

90. Freile-Pelegrin, Y.; Morales, J. Antibacterial activity in marine algae from the coast of Yucatan, Mexico. Bot. Mar. 2004, 47, 140-146. [CrossRef]

91. Gerasimenko, N.; Chaykina, E.; Busarova, N.; Anisimov, M. Antimicrobic and hemolytic activity of low-molecular metabolits of brown seaweed Laminaria cichorioides (Miyabe). Appl. Biochem. Microbiol. 2010, 46, 426-430. [CrossRef]

92. Val, A.; Platas, G.; Basilio, A.; Cabello, A.; Gorrochategui, J.; Suay, I.; Vicente, F.; Portillo, E.; Río, M.; Reina, G.; et al. Screening of antimicrobial activities in red, green and brown macroalgae from Gran Canaria (Canary Islands, Spain). Int. Microbiol. 2001, 4, 35-40. [CrossRef]

93. Shanab, S.M. Antioxidant and antibiotic activities of some seaweeds (Egyptian isolates). Int. J. Agric. Biol. 2007, 9, 220-225.

94. Capillo, G.; Savoca, S.; Costa, R.; Sanfilippo, M.; Rizzo, C.; Lo Giudice, A.; Albergamo, A.; Rando, R.; Bartolomeo, G.; Spanò, N.; et al. New insights into the culture method and antibacterial potential of Gracilaria gracilis. Mar. Drugs 2018, 16, 492. [CrossRef]

95. Wang, H.; Li, Y.L.; Shen, W.Z.; Rui, W.; Ma, X.J.; Cen, Y.Z. Antiviral activity of a sulfoquinovosyldiacylglycerol (SQDG) compound isolated from the green alga Caulerpa racemosa. Bot. Mar. 2007, 50, 185-190. [CrossRef]

96. Yap, W.F.; Tay, V.; Tan, S.H.; Yow, Y.Y.; Chew, J. Decoding antioxidant and antibacterial potentials of Malaysian green seaweeds: Caulerpa racemosa and Caulerpa lentillifera. Antibiotics 2019, 8, 152. [CrossRef] [PubMed]

97. Mattos, B.; Romanos, M.; de Souza, L.; Sassaki, G.; Barreto-Bergter, E. Glycolipids from macroalgae: Potential biomolecules for marine biotechnology? Rev. Bras. Farmacogn. 2011, 21, 244-247. [CrossRef]

98. Paul, V.; Fenical, W. Chemical defense in tropical green algae, order Caulerpales. Mar. Ecol. Prog. Ser. 1986, 34, 157-169. [CrossRef]

99. Stabili, L.; Acquaviva, M.; Angile, F.; Cavallo, R.; Cecere, E.; Del Coco, L.; Fanizzi, F.; Gerardi, C.; Narracci, M.; Petrocelli, A. Screening of Chaetomorpha linum lipidic extract as a new potential source of bioactive compounds. Mar. Drugs 2019, 17, 313. [CrossRef]

100. Marín-Álvarez, A.; Murillo-Álvarez, J.I.; Muñoz-Ochoa, M.; Molina-Salinas, G.M. Chemical constituents and bioactivity of Codium amplivesiculatum Setchell \& N. L. Gardener (Chlorophyta; Bryopsidales). CICIMAR Oceán. 2013, 28, 1-6.

101. Garg, H.; Sharma, M.; Bhakuni, D.; Pramanik, B.; Bose, A. An antiviral sphingosine derivative from the green alga Ulva fasciata. Tetrahedron Lett. 1992, 33, 1641-1644. [CrossRef]

102. Sharma, M.; Garg, H.; Chandra, K. Erythro-sphinga-4,8-dienine-N-palmitate-An antiviral agent from the green alga Ulva fasciata. Bot. Mar. 1996, 39, 213-215. [CrossRef]

103. El Baroty, G.S.; El-Baz, F.K.; Abd-Elmoein, I.; Abd El Baky Hanaa, H.; Ali, M.M.; Ibrahim, E.A. Evaluation of glycolipids of some egyptian marine algae as a source of bioactive substances. Int. Res. J. Pharm. 2011, 2, 165-174. 
104. Al-Fadhli, A.; Wahidulla, S.; D’Souza, L. Glycolipids from the red alga Chondria armata (Kutz.) Okamura. Glycobiology 2006, 16, 902-915. [CrossRef]

105. Mendes, M.; Pereira, R.; Pinto, I.S.; Carvalho, A.P.; Gomes, A.M. Antimicrobial activity and lipid profile of seaweed extracts from the North Portuguese Coast. Int. Food Res. J. 2013, 20, 3337-3345.

106. Manilal, A.; Sujith, S.; Selvin, J.; Kiran, G.S.; Shakir, C.; Lipton, A.P. Antimicrobial potential of marine organisms collected from the southwest coast of India against multiresistant human and shrimp pathogens. Sci. Mar. 2010, 74, 287-296. [CrossRef]

107. Ohta, K.; Mizushina, Y.; Hirata, N.; Takemura, M.; Sugawara, F.; Matsukage, A.; Yoshida, S.; Sakaguchi, K. Sulfoquinovosyldiacylglycerol, KM043, a new potent inhibitor of eukaryotic DNA polymerases and HIV-reverse transcriptase type 1 from a marine red alga, Gigartina tenella. Chem. Pharm. Bull. 1998, 46, 684-686. [CrossRef] [PubMed]

108. Stabili, L.; Acquaviva, M.I.; Biandolino, F.; Cavallo, R.A.; De Pascali, S.A.; Fanizzi, F.P.; Narracci, M.; Petrocelli, A.; Cecere, E. The lipidic extract of the seaweed Gracilariopsis longissima (Rhodophyta, Gracilariales): A potential resource for biotechnological purposes? New Biotechnol. 2012, 29, 443-450. [CrossRef]

109. Feng, M.; Yu, X.; Yang, P.; Yang, H.; Lin, K.; Mao, S. Two new antifungal polyunsaturated fatty acid ethyl esters from the red alga Laurencia okamurai. Chem. Nat. Compd. 2015, 51, 418-422. [CrossRef]

110. Vairappan, C.S.; Suzuki, M.; Ishii, T.; Okino, T.; Abe, T.; Masuda, M. Antibacterial activity of halogenated sesquiterpenes from Malaysian Laurencia spp. Phytochemistry 2008, 69, 2490-2494. [CrossRef]

111. De Souza, L.; Sassaki, G.; Romanos, M.; Barreto-Bergter, E. Structural characterization and anti-HSV-1 and HSV-2 activity of glycolipids from the marine algae Osmundaria obtusiloba isolated from Southeastern Brazilian coast. Mar. Drugs 2012, 10, 918-931. [CrossRef]

112. García-Bueno, N.; Dumay, J.; Guerin, T.; Turpin, V.; Paillard, C.; Stiger-Pouvreau, V.; Pouchus, Y.-F.; Marín-Atucha, A.A.; Decottignes, P.; Fleurence, J. Seasonal variation in the antivibrio activity of two organic extracts from two red seaweed: Palmaria palmata and the introduced Grateloupia turuturu against the abalone pathogen Vibrio harveyi. Aquat. Living Resour. 2015, 28, 81-87. [CrossRef]

113. Latorre, N.; Castaneda, F.; Meynard, A.; Rivas, J.; Contreras-Porcia, L. First approach of characterization of bioactive compound in Pyropia orbicularis during the daily tidal cycle. Lat. Am. J. Aquat. Res. 2019, 47, 826-840. [CrossRef]

114. Etahiri, S.; Bultel-Ponce, V.; Caux, C.; Guyot, M. New bromoditerpenes from the red alga Sphaerococcus coronopifolius. J. Nat. Prod. 2001, 64, 1024-1027. [CrossRef]

115. Amiguet, V.; Jewell, L.; Mao, H.; Sharma, M.; Hudson, J.; Durst, T.; Allard, M.; Rochefort, G.; Arnason, J. Antibacterial properties of a glycolipid-rich extract and active principle from Nunavik collections of the macroalgae Fucus evanescens C. Agardh (Fucaceae). Can. J. Microbiol. 2011, 57, 745-749. [CrossRef] [PubMed]

116. Plaza, M.; Santoyo, S.; Jaime, L.; Reina, G.; Herrero, M.; Senoráns, F.; Ibáñez, E. Screening for bioactive compounds from algae. J. Pharm. Biomed. Anal. 2010, 51, 450-455. [CrossRef] [PubMed]

117. El Shafay, S.M.; Ali, S.S.; El-Sheekh, M.M. Antimicrobial activity of some seaweeds species from Red sea, against multidrug resistant bacteria. Egypt. J. Aquat. Res. 2016, 42, 65-74. [CrossRef]

118. Gerasimenko, N.I.; Martyias, E.A.; Logvinov, S.V.; Busarova, N.G. Biological activity of lipids and photosynthetic pigments of Sargassum pallidum C. Agardh. Prikl. Biokhim. Mikrobiol. 2014, 50, 85-94. [CrossRef]

119. Plouguerné, E.; de Souza, L.M.; Sassaki, G.L.; Cavalcanti, J.F.; Villela Romanos, M.T.; da Gama, B.A.; Pereira, R.C.; Barreto-Bergter, E. Antiviral sulfoquinovosyldiacylglycerols (SQDGs) from the Brazilian brown seaweed Sargassum vulgare. Mar. Drugs 2013, 11, 4628-4640. [CrossRef]

120. Arunkumar, K.; Selvapalam, N.; Rengasamy, R. The antibacterial compound sulphoglycerolipid 1-0 palmitoyl-3-0(6'-sulpho-alpha-quinovopyranosyl)-glycerol from Sargassum wightii Greville (Phaeophyceae). Bot. Mar. 2005, 48, 441-445. [CrossRef]

121. Mendiola, J.; Torres, C.; Tore, A.; Martín-Álvarez, P.; Santoyo, S.; Arredondo, B.; Senoráns, F.; Cifuentes, A.; Ibáñez, E. Use of supercritical $\mathrm{CO}_{2}$ to obtain extracts with antimicrobial activity from Chaetoceros muelleri microalga. A correlation with their lipidic content. Eur. Food Res. Technol. 2007, 224, 505-510. [CrossRef]

122. Ohta, S.; Chang, T.; Kawashima, A.; Nagate, T.; Murase, M.; Nakanishi, H.; Miyata, H.; Kondo, M. Anti methicillin-resistant Staphylococcus aureus (MRSA) activity by linolenic acid isolated from the marine microalga Chlorococcum HS-101. Bull. Environ. Contam. Toxicol. 1994, 52, 673-680. [CrossRef] 
123. Herrero, M.; Ibáñez, E.; Cifuentes, A.; Reglero, G.; Santoyo, S. Dunaliella salina microalga pressurized liquid extracts as potential antimicrobials. J. Food Prot. 2006, 69, 2471-2477. [CrossRef]

124. Findlay, J.A.; Patil, A.D. Antibacterial constituents of the diatom Navicula delognei. J. Nat. Prod. 1984, 47, 815-818. [CrossRef]

125. Desbois, A.P.; Lebl, T.; Yan, L.; Smith, V.J. Isolation and structural characterisation of two antibacterial free fatty acids from the marine diatom, Phaeodactylum tricornutum. Appl. Microbiol. Biotechnol. 2008, 81, 755-764. [CrossRef] [PubMed]

126. Desbois, A.; Mearns-Spragg, A.; Smith, V. A fatty acid from the diatom Phaeodactylum tricornutum is antibacterial against diverse bacteria including multi-resistant Staphylococcus aureus (MRSA). Mar. Biotechnol. 2009, 11, 45-52. [CrossRef] [PubMed]

127. Ohta, S.; Shiomi, Y.; Kawashima, A.; Aozasa, O.; Nakao, T.; Nagate, T.; Kitamura, K.; Miyata, H. Antibiotic effect of linoleic acid from Chlorococcum strain HS-101 and Dunaliella primolecta on methicillin-resistant Staphylococcus aureus. J. Appl. Phycol. 1995, 7, 121-127. [CrossRef]

128. Li-Beisson, Y.; Thelen, J.; Fedosejevs, E.; Harwood, J. The lipid biochemistry of eukaryotic algae. Prog. Lipid Res. 2019, 74, 31-68. [CrossRef] [PubMed]

129. Hölzl, G.; Dörmann, P. Structure and function, of glycoglycerolipids in plants and bacteria. Prog. Lipid Res. 2007, 46, 225-243. [CrossRef] [PubMed]

130. Murakami, N.; Morimoto, T.; Imamura, H.; Ueda, T.; Nagai, S.; Sakakibara, J.; Yamada, N. Studies on glycolipids. III. Glyceroglycolipids from an axenically cultured cyanobacterium, Phormidium tenue. Chem. Pharm. Bull. 1991, 39, 2277-2281. [CrossRef] [PubMed]

131. Zhang, J.; Li, C.; Yu, G.; Guan, H. Total synthesis and structure-activity relationship of glycoglycerolipids from marine organisms. Mar. Drugs 2014, 12, 3634-3659. [CrossRef]

132. Banskota, A.; Stefanova, R.; Sperker, S.; Lall, S.; Craigie, J.; Hafting, J. Lipids isolated from the cultivated red alga Chondrus crispus inhibit nitric oxide production. J. Appl. Phycol. 2014, 26, 1565-1571. [CrossRef]

133. Wang, W.; Wang, S.X.; Guan, H.S. The antiviral activities and mechanisms of marine polysaccharides: An overview. Mar. Drugs 2012, 10, 2795-2816. [CrossRef]

134. Cerón, M.; García-Malea, M.; Rivas, J.; Acien, F.; Fernández, J.; Del Río, E.; Guerrero, M.; Molina, E. Antioxidant activity of Haematococcus pluvialis cells grown in continuous culture as a function of their carotenoid and fatty acid content. Appl. Microbiol. Biotechnol. 2007, 74, 1112-1119. [CrossRef]

135. Hsu, C.; Chao, P.; Hu, S.; Yang, C. The antioxidant and free radical scavenging activities of chlorophylls and pheophytins. Food Nutr. Sci. 2013, 4, 1-8. [CrossRef]

136. Bruce, D.L.; Duff, D.C.B.; Antia, N.J. The identification of two antibacterial products of the marine planktonic alga Isochrysis galbana. J. Gen. Microbiol. 1967, 48, 293-298. [CrossRef] [PubMed]

137. Carballeira, N.; Reyes, E.; Sostre, A.; Rodríguez, A.; Rodríguez, J.; González, F. Identification of the novel antimicrobial fatty acid (5Z,9Z)-14-methyl-5,9-pentadecadienoic acid in Eunicea succinea. J. Nat. Prod. 1997, 60, 502-504. [CrossRef] [PubMed]

138. Taniguchi, M.; Uchio, Y.; Yasumoto, K.; Kusumi, T.; Ooi, T. Brominated unsaturated fatty acids from marine sponge collected in Papua New Guinea. Chem. Pharm. Bull. 2008, 56, 378-382. [CrossRef]

139. Dmitrenok, A.; Radhika, P.; Anjaneyulu, V.; Subrahmanyam, S.; Rao, P.; Dmitrenok, P.; Boguslavsky, V. New lipids from the soft corals of the Andaman Islands. Russ. Chem. Bull. 2003, 52, 1868-1872. [CrossRef]

140. Angulo-Preckler, C.; Spurkland, T.; Avila, C.; Iken, K. Antimicrobial activity of selected benthic Arctic invertebrates. Polar Biol. 2015, 38, 1941-1948. [CrossRef]

141. Lauritano, C.; Martínez, K.A.; Battaglia, P.; Granata, A.; de la Cruz, M.; Cautain, B.; Martín, J.; Reyes, F.; Ianora, A.; Guglielmo, L. First evidence of anticancer and antimicrobial activity in Mediterranean mesopelagic species. Sci. Rep. 2020, 10,1-8. [CrossRef]

142. Barnathan, G. Non-methylene-interrupted fatty acids from marine invertebrates: Occurrence, characterization and biological properties. Biochimie 2009, 91, 671-678. [CrossRef]

143. Ely, R.; Supriya, T.; Naik, C.G. Antimicrobial activity of marine organisms collected off the coast of South East India. J. Exp. Mar. Bio. Ecol. 2004, 309, 121-127. [CrossRef]

144. Chan-Higuera, J.E.; Carbonell-Barrachina, A.A.; Cárdenas-Lopez, J.L.; Kačániová, M.; Burgos-Hernández, A.; Ezquerra-Brauer, J.M. Jumbo squid (Dosidicus gigas) skin pigments: Chemical analysis and evaluation of antimicrobial and antimutagenic potential. J. Microbiol. Biotechnol. Food Sci. 2019, 9, 349-353. [CrossRef] 
145. Seleghim, M.H.R.; Lira, S.P.; Kossuga, M.H.; Batista, T.; Berlinck, R.G.S.; Hajdu, E.; Muricy, G.; da Rocha, R.M.; do Nascimento, G.G.F.; Silva, M.; et al. Antibiotic, cytotoxic and enzyme inhibitory activity of crude extracts from Brazilian marine invertebrates. Rev. Bras. Farmacogn. 2007, 17, 287-318. [CrossRef]

146. Lin, K.; Yang, P.; Yang, H.; Liu, A.-H.; Yao, L.-G.; Guo, Y.-W.; Mao, S.-C. Lysophospholipids from the guangxi sponge Spirastrella purpurea. Lipids 2015, 50, 697-703. [CrossRef] [PubMed]

147. Linington, R.G.; Robertson, M.; Gauthier, A.; Finlay, B.B.; van Soes, R.; Andersen, R.J. Caminoside A, an antimicrobial glycolipid isolated from the marine sponge Caminus sphaeroconia. Org. Lett. 2002, 4, 4089-4092. [CrossRef] [PubMed]

148. Ravichandran, S.; Wahidulla, S.; D'Souza, L.; Rameshkumar, G. Antimicrobial lipids from the hemolymph of brachyuran crabs. Appl. Biochem. Biotechnol. 2010, 162, 1039-1051. [CrossRef]

149. Haug, T.; Kjuul, A.K.; Stensvåg, K.; Sandsdalen, E.; Styrvold, O.B. Antibacterial activity in four marine crustacean decapods. Fish. Shellfish Immunol. 2002, 12, 371-385. [CrossRef]

150. Schmitt, P.; Wilmes, M.; Pugnière, M.; Aumelas, A.; Bachère, E.; Sahl, H.-G.; Schneider, T.; Destoumieux-Garzón, D. Insight into invertebrate defensin mechanism of action oyster defensins inhibit peptidoglycan biosynthesis by binding to lipid II. J. Biol. Chem. 2010, 285, 29208-29216. [CrossRef]

151. Mohanraju, R.; Marri, D.B.; Karthick, P.; Narayana, S.; Murthy, K.N.; Ramesh, C. Antibacterial activity of certain cephalopods from Andamans, India. Int J. Pharm Biol Sci. 2013, 32, 450-455.

152. Cheng, L.; Jin, X.-K.; Li, W.-W.; Li, S.; Guo, X.-N.; Wang, J.; Gong, Y.-N.; He, L.; Wang, Q. Fatty acid binding proteins FABP9 and FABP10 participate in antibacterial responses in Chinese mitten crab, Eriocheir sinensis. PLOS ONE 2013, 8. [CrossRef]

153. Kelly, J.R.; Scheibling, R.E. Fatty acids as dietary tracers in benthic food webs. Mar. Ecol. Prog. Ser. 2012, 446, 1-22. [CrossRef]

154. Brinkmann, C.M.; Marker, A.; Kurtboke, D.I. An overview on marine sponge-symbiotic bacteria as unexhausted sources for natural product discovery. Diversity 2017, 9, 40. [CrossRef]

155. Laport, M.S.; Santos, O.C.S.; Muricy, G. Marine sponges: Potential sources of new antimicrobial drugs. Curr. Pharm. Biotechnol. 2009, 10, 86-105. [CrossRef] [PubMed]

156. Müller, W.E.G.; Blumbach, B.; Müller, I.M. Evolution of the innate and adaptive immune systems: Relationships between potential immune molecules in the lowest metazoan phylum (Porifera) and those in vertebrates. Transplantation 1999, 68, 1215-1227. [CrossRef]

157. Müller, W.E.G.; Klemt, M.; Thakur, N.L.; Schröder, H.C.; Aiello, A.; D’esposito, M.; Menna, M.; Fattorusso, E. Molecular/chemical ecology in sponges: Evidence for an adaptive antibacterial response in Suberites domuncula. Mar. Biol. 2004, 144, 19-29. [CrossRef]

158. Desbois, A.P.; Smith, V.J. Antibacterial free fatty acids: Activities, mechanisms of action and biotechnological potential. Appl. Microbiol. Biotechnol. 2010, 85, 1629-1642. [CrossRef]

159. Feldlaufer, M.F.; Knox, D.A.; Lusby, W.R.; Shimanuki, H. Antimicrobial activity of fatty acids against Bacillus larvae, the causative agent of American foulbrood disease. Apidologie 1993, 24, 95-99. [CrossRef]

160. Kabara, J.J.; Swieczkowski, D.M.; Conley, A.J.; Truant, J.P. Fatty acids and derivatives as antimicrobial agents. Antimicrob. Agents Chemother. 1972, 2, 23-28. [CrossRef]

161. Matsunaga, S.; Okada, Y.; Fusetani, N.; van Soest, R. An antimicrobial C14 acetylenic acid from a marine sponge Oceanapia species. J. Nat. Prod. 2000, 63, 690-691. [CrossRef]

162. Tasdemir, D.; Topaloglu, B.; Perozzo, R.; Brun, R.; O’Neill, R.; Carballeira, N.M.; Zhang, X.; Tonge, P.J.; Linden, A.; Ruedi, P. Marine natural products from the Turkish sponge Agelas oroides that inhibit the enoyl reductases from Plasmodium falciparum, Mycobacterium tuberculosis and Escherichia coli. Bioorg. Med. Chem. 2007, 15, 6834-6845. [CrossRef]

163. Tianero, M.D.B.; Hanif, N.; de Voogd, N.J.; van Soest, R.W.M.; Tanaka, J. A new antimicrobial fatty acid from the calcareous sponge Paragrantia cf. waguensis. Chem. Biodivers. 2009, 6, 1374-1377. [CrossRef]

164. Keffer, J.L.; Plaza, A.; Bewley, C.A. Motualevic acids A-F, antimicrobial acids from the sponge Siliquariaspongia sp. Org. Lett. 2009, 11, 1087-1090. [CrossRef]

165. Bifulco, G.; Bruno, I.; Minale, L.; Riccio, R. Novel HIV-inhibitory halistanol sulfates FH from a marine sponge, Pseudoaxinissa digitata. J. Nat. Prod. 1994, 57, 164-167. [CrossRef] [PubMed]

166. Sun, H.H.; Gross, S.S.; Gunasekera, M.; Koehn, F.E. Weinbersterol disulfate A and B, antiviral steroid sulfates from the sponge Petrosia weinbergi. Tetrahedron 1991, 47, 1185-1190. [CrossRef] 
167. Boonlarppradab, C.; Faulkner, D.J. Eurysterols A and B, cytotoxic and antifungal steroidal sulfates from a marine sponge of the genus Euryspongia. J. Nat. Prod. 2007, 70, 846-848. [CrossRef] [PubMed]

168. DiGirolamo, J.A.; Li, X.-C.; Jacob, M.R.; Clark, A.M.; Ferreira, D. Reversal of fluconazole resistance by sulfated sterols from the marine sponge Topsentia sp. J. Nat. Prod. 2009, 72, 1524-1528. [CrossRef] [PubMed]

169. Tsukamoto, S.; Matsunaga, S.; Fusetani, N.; van Soest, R.W.M. Acanthosterol sulfates A-J: Ten new antifungal steroidal sulfates from a marine sponge Acanthodendrilla sp. J. Nat. Prod. 1998, 61, 1374-1378. [CrossRef]

170. Viegelmann, C.; Parker, J.; Ooi, T.; Clements, C.; Abbott, G.; Young, L.; Kennedy, J.; Dobson, A.D.W.; Edrada-Ebel, R. Isolation and identification of antitrypanosomal and antimycobacterial active steroids from the sponge Haliclona simulans. Mar. Drugs 2014, 12, 2937-2952. [CrossRef]

171. Karthikeyan, S.C.; Velmurugan, S.; Donio, M.B.S.; Michaelbabu, M.; Citarasu, T. Studies on the antimicrobial potential and structural characterization of fatty acids extracted from Sydney rock oyster Saccostrea glomerata. Ann. Clin. Microbiol. Antimicrob. 2014, 13, 332. [CrossRef]

172. Carmely, S.; Roll, M.; Loya, Y.; Kashman, Y. The structure of eryloside A, a new antitumor and antifungal 4-methylated steroidal glycoside from the sponge Erylus lendenfeldi. J. Nat. Prod. 1989, 52, 167-170. [CrossRef]

173. Dai, H.-F.; Edrada, R.A.; Ebel, R.; Nimtz, M.; Wray, V.; Proksch, P. Norlanostane triterpenoidal saponins from the marine sponge Melophlus sarassinorum. J. Nat. Prod. 2005, 68, 1231-1237. [CrossRef]

174. Okada, Y.; Matsunaga, S.; van Soest, R.W.M.; Fusetani, N. Sokodosides, steroid glycosides with an isopropyl side chain, from the marine sponge Erylus placenta. J. Org. Chem. 2006, 71, 4884-4888. [CrossRef]

175. Ryu, G.; Choi, B.W.; Lee, B.H.; Hwang, K.-H.; Lee, U.C.; Jeong, D.S.; Lee, N.H. Wondosterols AC, three steroidal glycosides from a Korean marine two-sponge association. Tetrahedron 1999, 55, 13171-13178. [CrossRef]

176. Linington, R.G.; Robertson, M.; Gauthier, A.; Finlay, B.B.; MacMillan, J.B.; Molinski, T.F.; van Soest, R.; Andersen, R.J. Caminosides B-D, antimicrobial glycolipids isolated from the marine sponge Caminus sphaeroconia. J. Nat. Prod. 2006, 69, 173-177. [CrossRef] [PubMed]

177. Vanisree, M.; Subbaraju, G. Alcyonacean metabolites VIII-antibacterial metabolites from Labophytum crassum of the Indian Ocean. Asian J. Chem. 2002, 14, 957-960.

178. Butler, M.S.; Capon, R.J. The luffarins (AZ), novel terpenes from an Australian marine sponge, Luffariella geometrica. Aust. J. Chem. 1992, 45, 1705-1743. [CrossRef]

179. De Silva, E.D.; Scheuer, P.J. Three new sesterterpenoid antibiotics from the marine sponge Luffariella variabilis (Polejaff). Tetrahedron Lett. 1981, 22, 3147-3150. [CrossRef]

180. DeSilva, E.D.; Scheuer, P.J. Manoalide, an antibiotic sesterterpenoid from the marine sponge Luffariella variabilis (Polejaeff). Tetrahedron Lett. 1980, 21, 1611-1614. [CrossRef]

181. Kobayashi, J.; Yuasa, K.; Kobayashi, T.; Sasaki, T.; Tsuda, M. Jaspiferals A G, new cytotoxic isomalabaricanetype nortriterpenoids from Okinawan marine sponge Jaspis stellifera. Tetrahedron 1996, 52, 5745-5750. [CrossRef]

182. Sullivan, B.; Djura, P.; Mcintyre, D.E.; Faulkner, D.J. Antimicrobial constituents of the sponge Siphonodictyon coralliphagum. Tetrahedron 1981, 37, 979-982. [CrossRef]

183. Lee, D.; Shin, J.; Yoon, K.-M.; Kim, T.-I.; Lee, S.-H.; Lee, H.-S.; Oh, K.-B. Inhibition of Candida albicans isocitrate lyase activity by sesterterpene sulfates from the tropical sponge Dysidea sp. Bioorg. Med. Chem. Lett. 2008, 18, 5377-5380. [CrossRef]

184. Qiu, Y.; Wang, X.M. A new sesquiterpenoid hydroquinone from the marine sponge Dysidea arenaria. Molecules 2008, 13, 1275-1281. [CrossRef]

185. Takahashi, Y.; Kubota, T.; Ito, J.; Mikami, Y.; Fromont, J.; Kobayashi, J. Nakijiquinones G-I, new sesquiterpenoid quinones from marine sponge. Bioorg. Med. Chem. 2008, 16, 7561-7564. [CrossRef] [PubMed]

186. Zhang, H.; Khalil, Z.G.; Capon, R.J. Fascioquinols A-F: Bioactive meroterpenes from a deep-water southern Australian marine sponge, Fasciospongia sp. Tetrahedron 2011, 67, 2591-2595. [CrossRef]

187. Ishiyama, H.; Hashimoto, A.; Fromont, J.; Hoshino, Y.; Mikami, Y.; Kobayashi, J. Halichonadins A-D, new sesquiterpenoids from a sponge Halichondria sp. Tetrahedron 2005, 61, 1101-1105. [CrossRef]

188. Ishiyama, H.; Kozawa, S.; Aoyama, K.; Mikami, Y.; Fromont, J.; Kobayashi, J. Halichonadin F and the Cu(I) complex of halichonadin C from the sponge Halichondria sp. J. Nat. Prod. 2008, 71, 1301-1303. [CrossRef]

189. Appleton, D.R.; Chuen, C.S.; Berridge, M.V.; Webb, V.L.; Copp, B.R. Rossinones A and B, biologically active meroterpenoids from the Antarctic Ascidian, Aplidium species. J. Org. Chem. 2009, 74, 9195-9198. [CrossRef] [PubMed] 
190. Elkhayat, E.; Edrada, R.; Ebel, R.; Wray, V.; van Soest, R.; Wiryowidagdo, S.; Mohamed, M.; Müller, W.E.G.; Proksch, P. New luffariellolide derivatives from the Indonesian sponge Acanthodendrilla sp. J. Nat. Prod. 2004, 67, 1809-1817. [CrossRef] [PubMed]

191. Ross, S.A.; Weete, J.D.; Schinazi, R.F.; Wirtz, S.S.; Tharnish, P.; Scheuer, P.J.; Hamann, M.T. Mololipids, a new series of anti-HIV bromotyramine-derived compounds from a sponge of the order Verongida. J. Nat. Prod. 2000, 63, 501-503. [CrossRef]

192. Ata, A.; Win, H.; Holt, D.; Holloway, P.; Segstro, E.; Jayatilake, G. New antibacterial diterpenes from Pseudopterogorgia elisabethae. Helv. Chim. Acta 2004, 87, 1090-1098. [CrossRef]

193. Ibrahim, H.A.H. Antibacterial carotenoids of three Holothuria species in Hurghada, Egypt. Egypt. J. Aquat. Res. 2012, 38, 185-194. [CrossRef]

194. Mendes, G.; Soares, A.; Martins, F.; de Albuquerque, M.; Costa, S.; Yoneshigue-Valentin, Y.; Gestinari, L.; Santos, N.; Romanos, M. Antiviral activity of the green marine alga Ulva fasciata on the replication of human metapneumovirus. Rev. Inst. Med. Trop. Sao Paulo 2010, 52, 3-10. [CrossRef] [PubMed]

195. Jiang, Z.; Chen, Y.; Yao, F.; Chen, W.; Zhong, S.; Zheng, F.; Shi, G. Antioxidant, antibacterial and antischistosomal activities of extracts from Grateloupia livida (Harv). Yamada. PLoS ONE 2013, 8. [CrossRef] [PubMed]

196. Bligh, E.G.; Dyer, W.J. A rapid method of total lipid extraction and purification. Can. J. Biochem. Physiol. 1959, 37, 911-917. [CrossRef] [PubMed]

197. Folch, J.; Lees, M.; Stanley, G.H.S. A simple method for the isolation and purification of total lipides from animal tissues J. Biol. Chem. 1957, 226, 497-509.

198. Alves, E.; Simoes, A.; Domingues, M. Fruit seeds and their oils as promising sources of value-added lipids from agro-industrial byproducts: Oil content, lipid composition, lipid analysis, biological activity and potential biotechnological applications. Crit. Rev. Food Sci. Nutr. 2020. [CrossRef] [PubMed]

199. Maciel, E.; Leal, M.C.; Lillebø, A.I.; Domingues, P.; Domingues, M.R.; Calado, R. Bioprospecting of marine macrophytes using MS-based lipidomics as a new approach. Mar. Drugs 2016, 14, 49. [CrossRef] [PubMed]

200. Maciel, E.; Alves, E.; Domingues, P.; Domingues, R. Module 3-Lipidomics. In Advanced Analytical Chemistry for Life Sciences: AACLifeSci Course Companion Manual; Domingues, P., García, A., Skrzydlewska, E., Eds.; Medical University of Bialystok: Bialystok, Poland, 2018; pp. 120-134.

201. Malviya, N.; Malviya, S. Bioassay guided fractionation-an emerging technique influence the isolation, identification and characterization of lead phytomolecules. Hosp. Pharm. 2017, 2, 5. [CrossRef]

202. Cunha, L.C.S.; de Morais, S.A.L.; de Aquino, F.J.T.; Chang, R.; de Oliveira, A.; Martins, M.M.; Martins, C.H.G.; Sousa, L.C.F.; Barros, T.T.; da Silva, C.V.; et al. Bioassay-guided fractionation and antimicrobial and cytotoxic activities of Cassia bakeriana extracts. Rev. Bras. Farmacogn. 2017, 27, 91-98. [CrossRef]

203. Erenler, R.; Meral, B.; Sen, O.; Elmastas, M.; Aydin, A.; Eminagaoglu, O.; Topcu, G. Bioassay-guided isolation, identification of compounds from Origanum rotundifolium and investigation of their antiproliferative and antioxidant activities. Pharm. Biol. 2017, 55, 1646-1653. [CrossRef]

204. Thorgeirsdóttir, T.O.; Kristmundsdóttir, T.; Thormar, H.; Axelsdóttir, Í.; Holbrook, W.P. Antimicrobial activity of monocaprin: A monoglyceride with potential use as a denture disinfectant. Acta Odontol. Scand. 2006, 64, 21-26. [CrossRef]

205. Knightly, W.H. The physical properties of emulsifiers used in baking. In Physical Properties of Fats, Oils, and Emulsifiers; Widlak, N.W., Ed.; AOCS Press: Champaign, IL, USA, 1999; pp. 164-185.

206. Le, P.N.T.; Desbois, A.P. Antibacterial effect of eicosapentaenoic acid against Bacillus cereus and Staphylococcus aureus: Killing kinetics, selection for resistance, and potential cellular target. Mar. Drugs 2017, 15, 334. [CrossRef]

207. Delgado-Baquerizo, M.; Guerra, C.A.; Cano-Díaz, C.; Egidi, E.; Wang, J.-T.; Eisenhauer, N.; Singh, B.K.; Maestre, F.T. The proportion of soil-borne pathogens increases with warming at the global scale. Nat. Clim. Chang. 2020, 1-5. [CrossRef] 
208. FAO. The State of World Fisheries and Aquaculture 2020. Sustainability in Action; FAO: Rome, Italy, 2020. [CrossRef]

209. Benkendorff, K.; Davis, A.R.; Rogers, C.N.; Bremner, J.B. Free fatty acids and sterols in the benthic spawn of aquatic molluscs, and their associated antimicrobial properties. J. Exp. Mar. Biol. Ecol. 2005, 316, $29-44$. [CrossRef] 